\title{
"AVALIAÇÃO DO POTENCIAL FAUNÍSTICO DA A.R.I.E. CERRADO PÉ-DE-GIGANTE (PARQUE ESTADUAL DE VASSUNUNGA, SANTA RITA DO PASSA-QUATRO - SP), COM BASE NA ANÁLISE DE HABITATS"
}

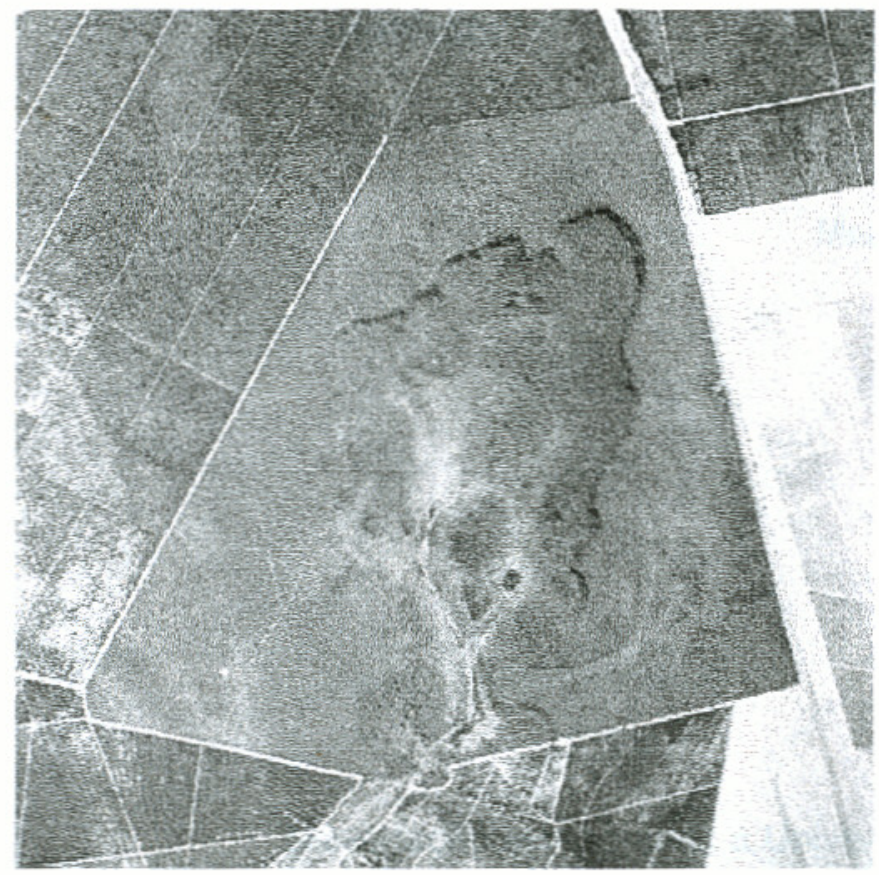

Mestranda: Maria Carolina Lyra Jorge Orientadora: Dra. Vânia Regina Pivello Instituição: Depto. de Ecologia Geral Instituto de Biociências da Universidade de São Paulo 
Universidade de São Paulo

Instituto de Biociências

Departamento de Ecologia Geral

"Avaliação do potencial faunístico da A.R.I.E. Cerrado Pé-de-Gigante, Parque Estadual do Vassununga, Santa Rita do Passa-Quatro, SP, com base na análise de habitats"

Maria Carolina Lyra Jorge

Dissertação apresentada à Universidade de São Paulo, Instituto de Biociências, Departamento de Ecologia Geral, como parte dos requisitos exigidos para obtenção do título de Mestre em Ecologia. 


\section{Ficha Catalográfica}

LYRA JORGE, M.C.

"Avaliação do potencial faunístico da A.R.I.E. Cerrado Pé-de-Gigante, Parque Estadual de Vassununga, Santa Rita do Passa-Quatro, SP, com base na análise de habitats".

83p. il., tabelas e gráficos

Dissertação de Mestrado - Departamento de Ecologia Geral - Instituto de Biociências Universidade de São Paulo (USP).

1. Cerrado; 2. Mamiferos; 3 . Preservação da biodiversidade; 4 . Unidade de Conservação 
Comissão Julgadora:

Prof. Dr.

Prof. Dr.

Orientadora

Profa. Dra. Vânia Regina Plvello 
Às pessoas mais importantes de minha vida, minha mãe e meu pai. 


\section{Agradecimentos:}

À Profa.Dra. Vânia Regina Pivello pela orientação, dedicação e confiança em mim depositada. À Vânia, uma pessoa querida, pela amizade e todas outras coisas boas que compartilhamos;

Ao Prof.Dr. Mário de Vivo, meu co-orientador, pelas dicas, paciência e eterno bom-humor;

À Profa.Dra. Yatio Yassuda e sua aluna Juliana Pagnozzi, pela simpatia com que sempre me receberam no Departamento de Genética da USP-SP;

Ao Prof.Dr. Sérgio Tadeu Meirelles pelo auxílilio, imprescindível, no tratamento estatístico dos dados;

À FAPESP, pelo auxilio financeiro e pela bolsa de estudos concedida durante a execução deste trabalho;

Ao Instituto Florestal de São Paulo, Estação Experimental de Luiz Antônio, pelas acomodações oferecidas, que permitiram minha estadia em campo durante a execução desta pesquisa;

À CELPAV, nos seus escritórios de Luiz Antônio e Jacareí, por estarem sempre de portas abertas;

Ao Dr. Rodrigo Teixeira, do Zoológico de Sorocaba, pelo auxilio na coleção de referência de fezes de mamíferos, e principalmente por sua amizade;

Às secretárias do Departamento de Ecologia Geral da USP, Dalva e Bernadete, pela presteza com que sempre me atenderam;

Aos técnicos do Departamento de Ecologia Geral da USP Lenilda e, especialmente ao Paulo César, pela ajuda nas campanhas de campo e ao Marcelo, pela infinita boa vontade com meus problemas computacionais;

Aos motoristas da seção de veículos, especialmente ao Valdir, por conduzir-nos com segurança;

Ao Sr. Edgar Rodrigues, meu auxiliar de campo, pela companhia e proteção que sempre fez questão de me oferecer; 
À Dra. Maria Tereza Jorge Pádua, minha tia, e Dr. Marc Duroujanni pelas sugestões, sempre construtivas;

Aos meus companheiros de campo, Alexandro Tozzeti, Luís Caldeira, Daniel Carvana e especialmente ao Glauco Kimura de Freitas, pelas viagens, pelas risadas e pelas cervejinhas;

Às companheiras de departamento, de orientadora e de campanhas de campo, Cláudia Shida, pela grande ajuda nas minhas dúvidas de fotointerpretação e Patrícia Ruggiero, uma artista em diagramas de perfil;

À grandes amigas que fiz na USP, Maria Cecília Lunardelli, que compartilhou comigo muitos momentos importantes deste trabalho e de minha vida e Alberta Gambuzzi, uma grande companheira de campo e uma super amiga "de cidade";

À pessoas realmente importantes para mim: Acácia Elias, Cristiane Rodrigues, Daniela Ariza, Eric Sulzer pela enorme amizade que nos une, e ao Marcelo B. Guimarães pela paciência e bom humor com meu temperamental computador;

Aos meus irmãos Leticia Lyra e Nicolau Jorge Neto, por serem, simplesmente, estas pessoas maravilhosas e à minha irmã de coração Simone Iwabe, amiga de muitos anos passados e se Deus quiser de muitos anos futuros;

Ao Eduardo Gualberto, que apareceu no final deste trabalho, mas tornou-se muito importante para mim, obrigado pelo seu interesse e estimulo;

Ao Prof.Dr. Miguel Trefaut Rodrigues, quem eu considero um verdadeiro mestre, pelos ensinamentos e oportunidades, e acima de tudo pela amizade e carinho que são impagáveis. 


\section{Sumário}

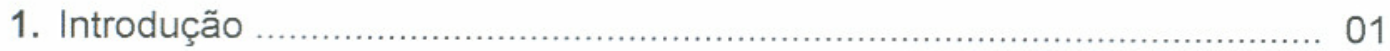

1.1 A diversidade biológica do cerrado e sua situação no Brasil e no Estado de São Paulo..... 01

1.2. Estratégias para conservação biológica em ambientes fragmentados .05

1.3. Justificativa e objetivos deste estudo 06

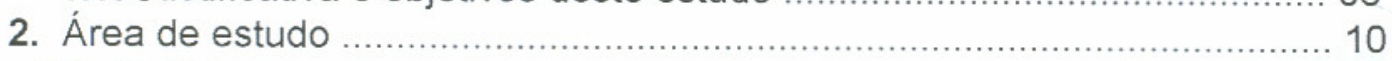

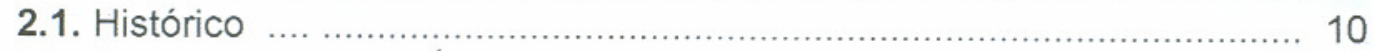

2.2. Caracterização da Área …........................................................... 12

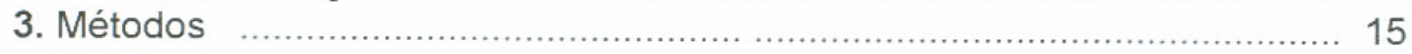

3.1. Mamíferos de médio e grande porte .................................................. 15

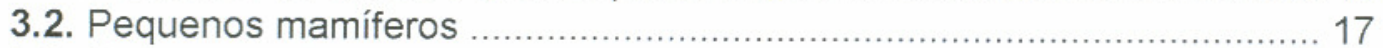

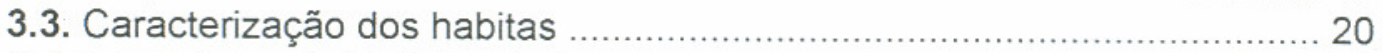

3.4. Levantamento histórico da fauna ...................................................... 21

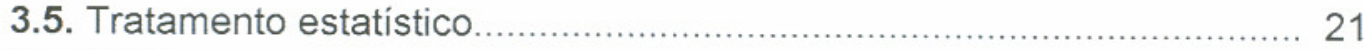

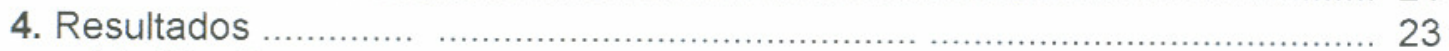

4.1. Mamíferos de médio e grande porte................................................. 23

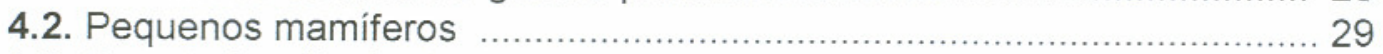

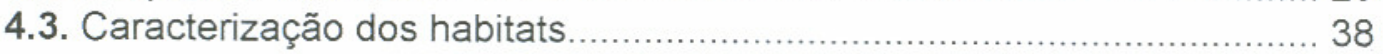

4.4. Levantamento histórico da fauna..................................................... 51

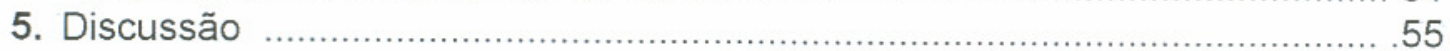

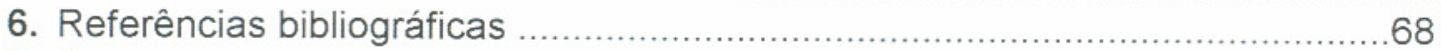

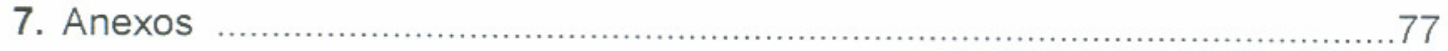

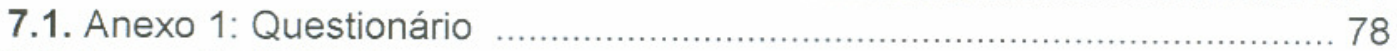

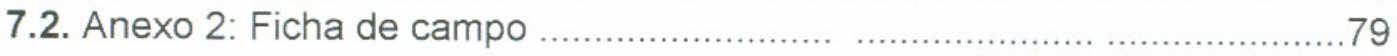




\section{Lista de figura e tabelas:}

\section{Figuras:}

- Figura 1: Distribuição do domínio geomorfológico dos cerrados, no Brasil (Fonte: IBGE, 1992);

- Figura 2: Gradiente estrutural do Cerrado (modificado de Coutinho, 1982);

- Figura 3: Áreas originalmente cobertas por cerrado no estado de São Paulo (Fonte: SEMA, 1997);

- Figura 4: Localização de algumas espécies ameaçadas de extinção no Estado de São Paulo (Fonte: SEMA, 1997);

- Figura 5: Localização do município de Santa Rita do Passa-Quatro no Estado de São Paulo, onde se encontra a A.R.I.E. (modificado de Salis et al, 1995);

- Figura 6: Localização das glebas (1) Capão da Várzea, (2) Capetinga, (3) Praxedes, (4) Maravilha, (5) Capetinga Leste e (6) Pé-de-Gigante, pertencentes ao Parque Estadual de Vassununga, em Santa Rita do Passa-Quatro, SP;

- Figura 7: Fotografia aérea da A.R.I.E. Cerrado Pé-de-Giagante, Santa Rita do Passa-Quatro, SP, em reconhecimento aéreo realizado em 1988;

- Figura 8: Diagrama climático segundo Walther \& Lieth para A.R.I.E., construído com dados meteorológicos de 1985 a 1994 da Estação Meteorológica do DAEE em Santa Rita do Passa-Quatro, SP (Fonte: Mesquita Jr., 1998);

- Figura 9: Uso das terras na região onde se encontra a A.R.I.E. Cerrado Pé-de-Gigante (Fonte: Shida, C.N., in prep.);

- Figura 10: Localização das fisionomias e o circuito utilizado para amostragem de mamíferos na A.R.I.E. Cerrado Pé-de-Gigante (Fonte: Mesquita Jr., 1998);

- Figura 11: Canteiro de areia utilizado para verificação de pegadas de mamíferos de médio e grande porte;

- Figura 12: Armadilha tipo gaiola utilizada na captura de pequenos mamiferos

- Figura 13: Estação de pitfall para coleta de pequenos mamíferos;

- Figura 14: Roedores taxidermixados;

- Figura 15: Frequência de ocorrência dos mamiferos de médio e grande porte, detectados através de avistamentos, fezes e pegadas; 
- Figura 16: Grupos de animais de médio e garnde porte registrados na A.R.I.E.;

- Figura 17: Fezes de Mazama sp;

- Figura 18: Pegadas de Mazama sp;

- Figura 19: Pegadas de Chrysocyon brachyurus;

- Figura 20: Fezes de Chrysocyon brachyurus;

- Figura 21: Exemplar de Chrysocyon brachyurus encontrado atropelado na Via Anhanguera defronte à A.R.I.E. Cerrado Pé-de-Gigante;

- Figura 22: Pegadas de Felis concolor,

- Figura 23: Carcaça de tatu caçada por um indivíduo de Felis concolor,

- Figura 24: Indivíduo de Dusicyon thous;

- Figura 25: Pegada de Conepatus chinga;

- Figura 26: Dendrograma resultante da análise de agrupamento com método da mínima variância e o coeficiente da distância euclidiana, comparando as fisionomias onde foram amostrados os mamíferos de médio e grande portes;

- Figura 27: Indivíduo de Gracilinanus microtarsus;

- Figura 28: Indivíduo de Didelphis albiventris;

- Figura 29: Curvas de suficiência amostral comparando os métodos utilizados para captura dos pequenos mamíferos;

- Figura 30: Dendrograma resultante da análise de agrupamento com o método da mínima variância e o coeficiente da dsitância euclidiana, comparando as diferentes fisionomias estudadascom relação aos pequenos mamiferos amostrados;

- Figura 31: Localização dos habitats preferenciais dos pequenos mamiferos da A.R.I.E. cerrado Pé-de-Gigante;

- Figura 32: Frequência de ocorrência comparativa entre roedores e marsupiais nas diferentes fitofisionomias na A.R.I.E. Cerrado Pé-de-Gigante;

- Figura 33: Sucesso de captura de roedores e marsupiais ao longo do período de coletas, na A.R.I.E. Cerrado Pé-de-Gigante;

- Figura 34: Precipitação $(\mathrm{mm})$ e temperatura $\left({ }^{\circ} \mathrm{C}\right)$ ao longo do periodo de coletas no município de Santa Rita do Passa-Quatro (Fonte: CELPAV);

- Figura 35: Relação entre o número de capturas e a precipitação pluviométrica $(\mathrm{mm})$ ao longo do periodo de coletas; 
- Figura 36: Periodo de frutificação e floração e sua relação com as capturas. Dados fenológicos obtidos por Batalha, 1997;

- Figura 37: Medidas morfométricas tomadas dos pequenos mamíferos em campo;

- Figura 38: Diagrama de perfil do campo úmido, segundo Batalha, 1997;

- Figura 39: Diagrama de perfil da floresta estacional semi-decidual, segundo Batalha, 1997;

- Figura 40: Diagrama de perfil da floresta ripária, segundo Batalha, 1997;

- Figura 41: Diagrama de perfil do cerrado sensu stricto, segundo Batalha, 1997;

- Figura 42: Diagrama de perfil do campo cerrado, segundo Batalha, 1997;

- Figura 43: Diagrama de perfil da floresta homogênea de eucaliptos (Elaborado por Rugiero, P.G.C.);

- Figura 44: Dendrograma resultante da análise de agrupamento com o método da mínima variância e coeficiente da distância euclidiana, comparando as diferentes fisionomias estudadas com relação às suas características fisiográficas;

- Figura 45: Gráfico de interpretação dos primeiro e segundo eixos resultantes da análise de correspondência com o alogarítimo da média recíproca, para relacionar as fisionomias às capturas dos pequenos mamiferos;

- Figura 46: Dados meteorológicos do dia 02/04/98, coletados na borda da A.R.I.E. Cerrado péde-Gigante;

- Figura 47: Localização das principais perturbações antropogênicas do interior e no entorno da A.R.I.E. Cerrado Pé-de-Gigante (Fonte Pivello, 1996);

- Figura 48: Espécies avistadas pela população local, conforme dados obtidos com as entrevistas realizadas;

- Figura 49: Espécies mais caçadas pela população local.

\section{Tabelas:}

- Tabela 1: Ocorrência dos mamíferos de médio e grande porte nas diferentes fisionomias vegetais;

- Tabela 2: Frequência de ocorrência dos pequenos mamíferos nas diferentes fisionomias vegetais, e porcentagem (\%) das espécies por ambiente; 
xii

- Tabela 3: Índice de Shannon- Wienner, dos pequenos mamíferos, para cada fisionomia amostrada;

- Tabela 4: Dados morfométricos dos roedores capturados na A.R.I.E. Cerrado Pé-de-Gigante;

- Tabela 5: Dados morfométricos dos marsupiais capturados na A.R.I.E. Cerrado Pé-de-Gigante;

- Tabela 6: Carcaterísticas fisiográficas dos habitats amostrados na A.R.I.E.;

- Tabela 7: Dados meteorológicos, de intensidade luminosa e cobertura vegetal das fisionomias amostradas e no exterior da A.R.I.E. Cerrado Pé-de-Gigante;

- Tabela 8: Opinião da população local sobre a influência dos reflorestamentos de eucalipto na mastofauna da região de Santa Rita do Passa-Quatro e Luiz Antônio, SP (\%);

- Tabela 9: Prática da caça pela população na região da A.R.I.E. Cerrado Pé-de-Gigante;

- Tabela 10: Espécies de mamíferos reintroduzidas na Estação Ecológica de Jataí, Luís Antônio, SP. 


\section{Introdução :}

\subsection{A diversidade biológica do Cerrado e sua situação no Brasil e no Estado de São Paulo:}

O Brasil é o detentor de uma das maiores biodiversidades do planeta, abrigando de 15 a 20\% das espécies vivas (WRI/UICN/PNUMA 1992). Entretanto, somente cerca de $3,7 \%$ da extensão territorial do país se encontra protegida em unidades de conservação federais de uso direto e indireto dos recursos naturais (UICN,1982). Este número pode aumentar um pouco se considerarmos todas as unidades de conservação, de âmbito estadual, municipal e as particulares; estas, porém, são invariavelmente fragmentos bastante reduzidos em área.

O domínio geomorfológico dos cerrados é a segunda maior formação vegetal do Brasil, abrangendo aproximadamente um quarto do território, ou seja, cerca de 1,8 a 2 milhões de km² (Ab'Saber, 1971). Sua região nuclear ou "core" , considerada mais característica e contínua, ocupando 1,5 milhões de $\mathrm{km}^{2}$, está situada no Planalto Central Brasileiro, que possui $85 \%$ de sua extensão dominada por este tipo de paisagem (Eiten, 1982) (figura 1). De maneira disjunta, as formações de cerrado distribuem-se também marginalmente por estados no norte e nordeste do país, além do Estado de São Paulo e Paraná, mesclando-se com outros biomas, como a caatinga e a mata Atlântica (Eiten, 1978).

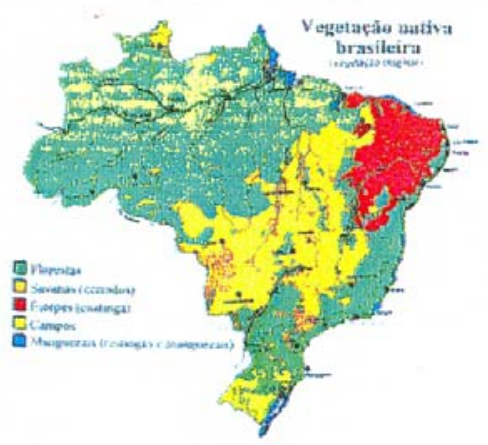

Figura 1: Distribuição do domínio geomorfológico dos Cerrados, no Brasil. (Fonte:IBGE,1992). 
A palavra "cerrado" significa "fechado" ou "vegetação densa". Até o final do século passado, as formações vegetais do Brasil Central eram conhecidas pelo nome genérico de "tabuleiros"; onde a vegetação rasteira era bem desenvolvida, eram conhecidas por "tabuleiros cerrados". Na segunda metade do século passado, "tabuleiro" passou a ser denominado "campo", e as formações vegetais passaram a ser denominadas "campo limpo", "campo sujo", e "campo cerrado". Mais recentemente, o termo "cerrado" foi adotado no meio científico para designar a vegetação característica que ocorre na região central do Brasil (WWF, 1995), que é um complexo de formações vegetais que apresentam fisionomia e composição florística variáveis, num gradiente que vai de cerradão a campo limpo (Coutinho, 1978). Segundo Goodland \& Ferri (1979), "o cerrado é uma mistura de árvores baixas e um bem desenvolvido estrato herbáceo rasteiro" (figura 2).

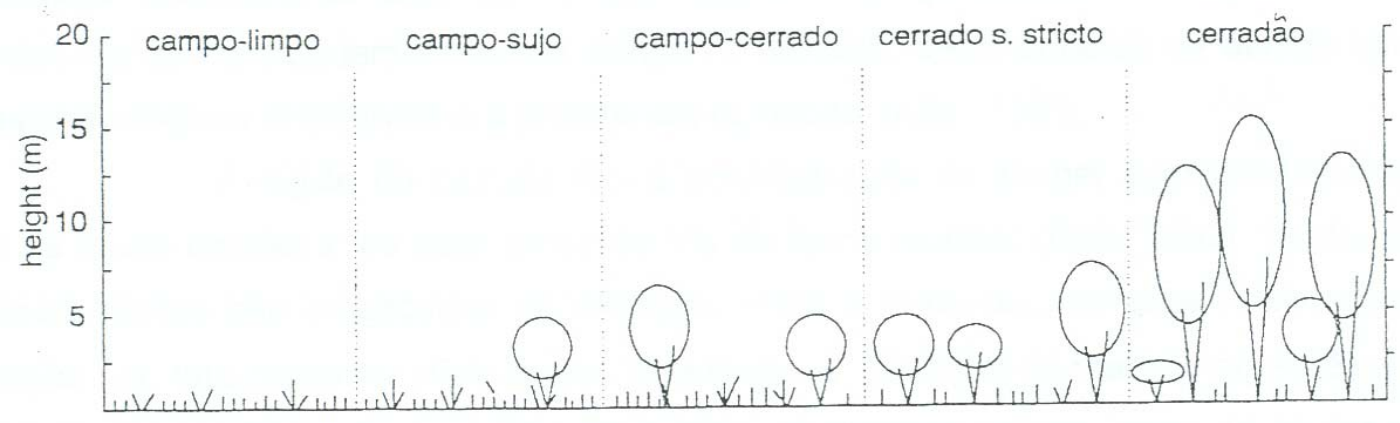

Figura2: Gradiente estrutural do Cerrado (modificado de Coutinho, 1982)

Assim, pode-se dizer que a fisionomia peculiar do Cerrado constitui um "tapete" em que predominam as gramíneas e que reveste o solo de maneira mais ou menos completa e onde se desenvolvem árvores e arbustos, ora isolados, ora em grupos, geralmente tortuosos, de cascas espessas, com frequentes sinais de queima, de folhas grandes, simples ou divididas, coriáceas, brilhantes ou revestidas de numerosos pêlos. Esse tipo peculiar de vegetação, que lembra pela fisionomia certas savanas da África, era tido como devido à falta de água; era comum chamar-se cerrado os campos secos. Sabe-se hoje, todavia, que o Cerrado não é condicionado pela escassez de água, mas pela pobreza dos solos onde se encontra, ou por ações antropogênicas periódicas, como queima e/ou corte.

A flora do Cerrado é considerada a mais rica dentre as savanas do mundo; sua riqueza em árvores e arbustos é muito superior ao número de espécies das savanas do 
Suriname ou Venezuela (WWF, 1995). Esta diversidade notável foi primeiramente demonstrada por Warming (1963) e, posteriormente, por Rizzini (1971) que apresentou 537 espécies entre árvores e arbustos, por Heringer et al (1977), com 774 espécies arbustivas e arbóreas e por Filgueiras \& Pereira (1990), que só para o Distrito Federal listaram 2264 espécies vasculares; Mendonça et al. (1998) listaram 6429 espécies, que incluem 451 variedades e/ou subespécies. Este número é superior ao da maioria das floras do mundo (Pereira, 1992). As famílias dominantes na paisagem de cerrado são Leguminosae, Poaceae, Asteraceae, Rubiaceae, Palmaceae, Anonaceae (Rizzini, 1992; Felfili et al., 1996).

A grande diversidade encontrada no cerrado não se limita somente ao número de espécies (diversidade $\alpha$ ), mas é também encontrada na variedade de habitats (diversidade $\beta$ ) e de paisagens (diversidade $\gamma$ ), já que o bioma engloba diferentes formações vegetais, como campos, floresta semidecídua, floresta ripária, veredas, além das fisionomias de cerrado propriamente dito. Em virtude dessa heterogeneidade de habitats, diversas espécies de animais podem encontrar abrigo no cerrado, distribuindo-se de acordo com os recursos ecológicos disponíveis e à preferência de habitat (Alho, 1981).

A região do cerrado tem a potencialidade de abrigar aproximadamente um terço da fauna brasileira, ou seja, cerca de $5 \%$ da fauna mundial (Dias, 1992). Dentre essas espécies, muitas são ameaçadas de extinção, como o tamanduá-bandeira (Myrmecophaga tridactyla), o tatu-canastra (Priodontes maximus), o cachorro-do-mato-vinagre (Speothos venaticus). Há também vários endemismos entre os diversos grupos, como $16 \%$ das aves, $23 \%$ dos répteis e $21 \%$ dos mamíferos, citando-se, por exemplo, o roedor Juscelinomys candango e o marsupial Monodelphis unistrata (Jorge Pádua, 1992).

Apesar de toda esta riqueza natural e de sua grande extensão, o Cerrado é um bioma ainda esquecido no que se refere à sua proteção legal e efetiva, através de unidades de conservação. O cerrado não recebeu status de patrimônio nacional concedido para a Amazônia, Mata Atlântica, Pantanal e Sistemas Costeiros na mais recente Constituição Brasileira. A carência de áreas de conservação no bioma evidencia-se pela comparação do esforço conservacionista governamental entre os ecossistemas amazônicos, que contam com $12 \%$ de sua área protegida na forma de unidades de conservação, contra menos de $2 \%$ no cerrado (WWF, 1995).

Como agravante da situação, temos o fato de que, entre 1970 e 1990, a área das principais culturas agrícolas no cerrado cresceu $120 \%$, em detrimento de ecossistemas naturais (de 4,6 para 10,2 milhões de hectares) (Lopes et al, 1996). O forte êxodo de agricultores do sul do país nas décadas de 70 e 80 , à procura de terras baratas, na região do 
Centro-Oeste tornou a monocultura de soja a cultura mais expressiva da região (Wallis, 1993 apud Lopes et alli, 1996). Contribuiu ainda para a exploração do Cerrado o fato de que, em geral, seus solos possuem topografia e textura favoráveis à mecanização (Goedert, 1985), apesar de serem pouco férteis e dependerem de correções químicas (Lopes et al., 1996).

Toda esta situação de exploração agrícola em regiões de cerrado tendem a piorar ainda mais com a Medida Provisória n 1736-31, assinada no ano de 1998 pelos exministros Gustavo Krause (Meio Ambiente) e Francisco Turra (Agricultura), diminuindo a área de preservação obrigatória dentro de propriedades particulares de 50 para $20 \%$, devido à expansão da agricultura e pecuária nas regiões de cerrado do Brasil central.

No Estado de São Paulo, a situação do cerrado é bastante crítica, justamente pelo fato de ser o Estado que mais sofreu ação antrópica do país; as raras manchas de cerrado que ainda restam são alvos constantes do desejo de agricultores, devido à proximidade de centros consumidores e da topografia plana que predomina nestas áreas (Toledo Filho, 1984 apud SEMA, 1997), onde investimentos em mecanização compensam a baixa fertilidade dos solos. Por este motivo, estas áreas vêm sendo ocupadas por atividades agropecuárias, principalmente cana-de-açúcar, citricultura e gado bovino. Além disso, convém lembrar que desde o início deste século, regiões de cerrado vêm funcionando como fornecedoras de lenha, carvão vegetal, moirões de cerca, e pasto natural na pecuária (SEMA,1997).

Assim, dos $14 \%$ de área do estado de São Paulo originalmente recoberta por diferentes formações de cerrado, o pouco que resta encontra-se principalmente na região centro-norte, como nas proximidades de Campinas, Ribeirão Preto, Franca, e Altinópolis (Toledo Filho, 1984 apud SEMA, 1997), em alto grau de fragmentação (figura 3).

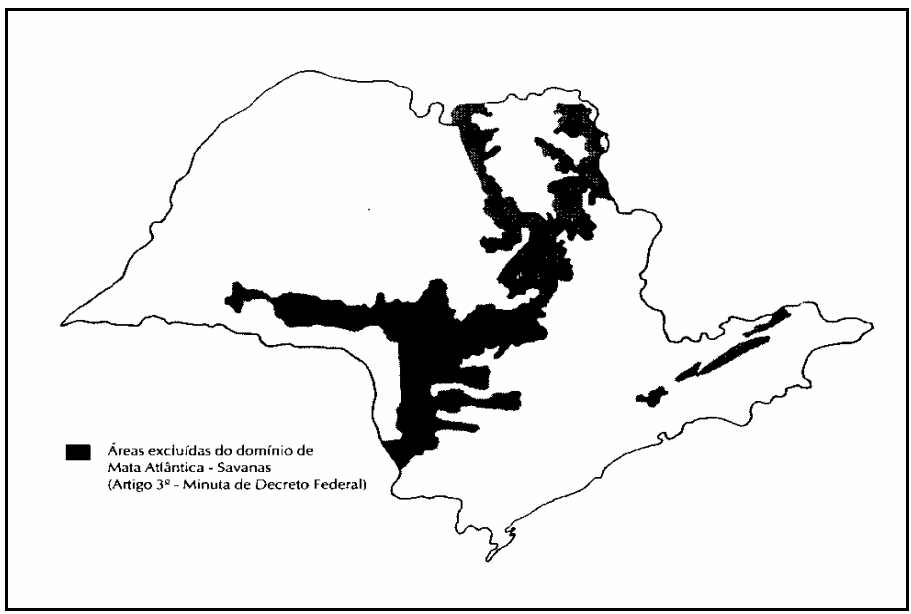

Figura 3: Áreas originalmente cobertas por cerrado no Estado de São Paulo.

(Fonte: SEMA, 1997). 
A fragmentação dos ambientes naturais, como florestas, cerrados e campos é, na atualidade, uma das maiores ameaças à diversidade biológica. No Estado de São Paulo, onde a cobertura vegetal natural apresenta-se hoje quase totalmente modificada e fragmentada, as áreas naturais extensas e pouco perturbadas são cada vez mais raras (Morelatto \& Leitão Filho, 1995).

A fauna típica da vegetação dos cerrados de São Paulo é pouco conhecida e os mamíferos não são exceção, inclusive com espécies novas sendo ainda coletadas e descritas (Fonseca \& Redford, 1984). A situação se torna ainda mais delicada se considerarmos que espécies altamente ameaçadas de extinção fazem parte desta fauna tão pouco estudada. É, portanto, imprescindível a proteção de manchas remanescentes, procurando manter estes últimos refúgios da biodiversidade do nosso Estado, bem como o estudo da biologia das espécies que lá vivem e o conhecimento de suas necessidades básicas, a fim de se perpetuar a sobrevivência destas populações.

\subsection{Estratégias para conservação biológica em ambientes fragmentados:}

A conservação in situ é o método mais eficaz para se manter intactas a complexa estrutura e dinâmica das interações entre espécies e, em consequência, a continuidade dos processos evolutivos que originam e mantêm a biodiversidade (Santos Filho, 1995; DeGraff \& Miller, 1996). Um fragmento natural grande é especialmente necessário para espécies de interior ou aquelas com grandes áreas domiciliares, uma vez que áreas maiores podem abrigar um maior número de espécies, além de populações maiores, proporcionando, assim, uma maior variação genética intraespecífica.

Sabemos, porém, que fragmentos naturais grandes estão cada vez mais escassos, devido à ocupação humana (Gilpin, 1996). Portanto, a criação de corredores de vegetação entre fragmentos menores, monitorados, que permitam conectividade entre os fragmentos nativos e entre suas populações, favorecendo a movimentação da fauna numa matriz que ofereça uma certa resistência às pressões do entorno, é uma das estratégias para ajudar na conservação da fauna destes fragmentos, resistindo a extinções (DeGraff \& Miller 1996; Budry \& Merriam, 1988). O fluxo gênico resultante da movimentação da fauna entre os 
diversos fragmentos nativos permite a recolonização de fragmentos intercomunicantes na paisagem, criando entre eles um sistema de metapopulações (Gotteli \& Kelley, 1993).

A dinâmica de uma metapopulação depende basicamente de 1) o tamanho dos fragmentos e a qualidade dos habitats neles contidos; 2) a conectividade entre os fragmentos; 3) a permeabilidade da matriz da paisagem; 4) a taxa de dispersão entre os fragmentos (conectividade funcional) (Opdam, 1988). Tudo isso porque, para se conservar uma população a longo prazo, ela deve ter um tamanho mínimo viável, que resista a flutuações em seu tamanho, por motivos naturais ou estocásticos (demográficos ou ambientais), mantendo uma heterozigose suficiente para não sofrer degenerações genéticas devido à consanguinidade (Shafer, 1990). Numa população de mamíferos de médio ou grande porte, que requisite uma grande área domiciliar, o conceito de conectividade torna-se ainda mais importante, pois permite a manutenção da população, respeitando sua territorialidade e etologia.

\subsection{Justificativa e Objetivos deste Estudo:}

A A.R.I.E. Cerrado Pé-de-Gigante, objeto deste estudo, é uma das poucas manchas remanescentes de cerrado do Estado de São Paulo. Este fato, por si só, já seria suficiente para justificar seu estudo e conservação. Mas, além disso, ainda responde a todos os critérios estabelecidos como prioritários à proteção de manchas dos cerrados paulistas, quais sejam (SEMA, 1997):

- presença de espécies animais raras, ameaçadas ou endêmicas (obedecendo critérios da UICN,1994);

- heterogeneidade ambiental: presença de um mosaico de ambientes ou habitats;

- singularidade ecológica: existêncianas áreas de atributos não ocorrentes em outros remanescentes;

- tamanho da área, priorizando áreas maiores que 100 ha;

- proximidade e conectividade com outros remanescentes, formando arquipélagos;

- presença de remanescentes de floresta mesófila, matas decíduas e várzeas no fragmento, além das fisionomias de cerrado.

Tais critérios estão de acordo com aqueles estabelecidos por MacKinnon et al. (1986). 
Um ponto a ser ressaltado refere-se à situação privilegiada da A.R.I.E. Cerrado Pé-de-Gigante, pois, juntamente com as diversas glebas do Parque Estadual do Vassununga e com a Estação Ecológica de Jataí, forma um "arquipélago" de vegetação natural, que, na grande maioria das vezes possui reflorestamentos de eucalipto entre os fragmentos de vegetação nativa. Observações preliminares indicam que estes reflorestamentos parecem exercer um efeito satisfatório no que diz respeito à conectividade dos remanescentes naturais. $A$ proteção dedicada a estas florestas pelas companhias de reflorestamento tornaram-nas verdadeiros corredores entre as diversas manchas de cerrado, proporcionando abrigo e moradia à fauna de grande porte e de maior área domiciliar. Porém, apesar de se admitir que a monocultura de eucalipto oferece uma conectividade relativamente boa entre os fragmentos naturais, é necessário ressaltar que a quantidade e diversidade de espécies animais que podem ser encontradas numa monocultura, quer de eucalipto ou de qualquer outra espécie, é reconhecidamente menor que a de qualquer ecossistema florestal nativo (Paula Lima, 1996).

Uma plantação silvicultural não é absolutamente uniforme, mas consiste em um verdadeiro mosaico de talhões de diferentes idades, desde áreas recentemente cortadas até povoamentos de diferentes idades e estrutura. Essa diversidade espacial por si só já resulta em algum benefício para a fauna; tais condições poderiam ainda ser melhoradas pela adoção de práticas adequadas de manejo (Paula Lima, 1996).

Com base em conceitos modernos de manejo ecossistêmico ou integrado, existe hoje uma preocupação na busca de práticas que visem minimizar os impactos aos ecossistemas nativos por florestas plantadas. Com relação à silvicultura de eucaliptos, grandes avanços já foram alcançados com este tipo de estudo, como, por exemplo, a manutenção de um sub-bosque sob o eucalipto, para melhorar a fixação de nitrogênio pelas plantas, contribuindo, assim, para a conservação dos nutrientes no sistema (Fonseca, 1984 apud Paula Lima, 1996).

Quanto à fauna, muitos estudos revelaram que as plantações de florestas de eucalipto não são, na realidade, destituídas de fauna. Porém, é com relação à decisiva melhoria nas condições de habitat que se pode conseguir, com a aplicação de práticas de manejo florestal adequadas, uma diversidade faunística satisfatória (Paula Lima, 1996).

Medidas muito simples têm sido recomendadas para o propósito de inclusão de conservação da biodiversidade nos planos de manejo integrado de plantações florestais, tais como: favorecer a diversidade etária das plantações; aumentar o quanto possível a variabilidade de habitats ao longo da área, tais como áreas abertas, lagos e açudes, capões de vegetação natural; implantar corredores de vegetação natural ao longo de um curso d'água e 
interligando fragmentos naturais por entre a floresta plantada; repensar a utilização de fertilizantes minerais e herbicidas, uma vez que podem afetar a fauna e a microbiologia do solo (Paula Lima, 1996).

Pouquissímos estudos relativos à fauna foram desenvolvidos na A.R.I.E. Cerrado Pé-de-Gigante. Levantamentos de mamíferos realizados em fragmentos próximos a este, além de relatos de pessoas que conhecem a A.R.I.E., revelam uma grande biodiversidade local, inclusive a existência de espécies que constam da lista oficial das espécies ameaçadas de extinção divulgada pelo Instituto Brasileiro do Meio Ambiente e dos Recursos Naturais Renováveis (Bernardes et al, 1990) e na lista da fauna ameaçada no estado de São Paulo (SEMA, 1998) (figura 4).

Para a elaboração do plano de manejo de uma unidade de conservação, instrumento básico para a conservação de recursos naturais, é imprescindível o conhecimento dos recursos biológicos que contém, bem como sua relação com os fatores abióticos. Assim, dado o total desconhecimento da fauna local e a consciência da necessidade de sua proteção, este estudo foi idealizado visando a elaboração de um inventário dos mamíferos não-voadores que ocorrem na A.R.I.E. Cerrado Pé-de-Gigante e o relacionamento desta fauna a seu habitat, verificando suas necessidades para a sobrevivência e preservação das populações. A comprovação da ocorrência aí de espécies ameaçadas é importantíssima para reforçar que a proteção de refúgios como este deve ser priorizada, procurando manter assim o que resta da biodiversidade do Estado de São Paulo. 

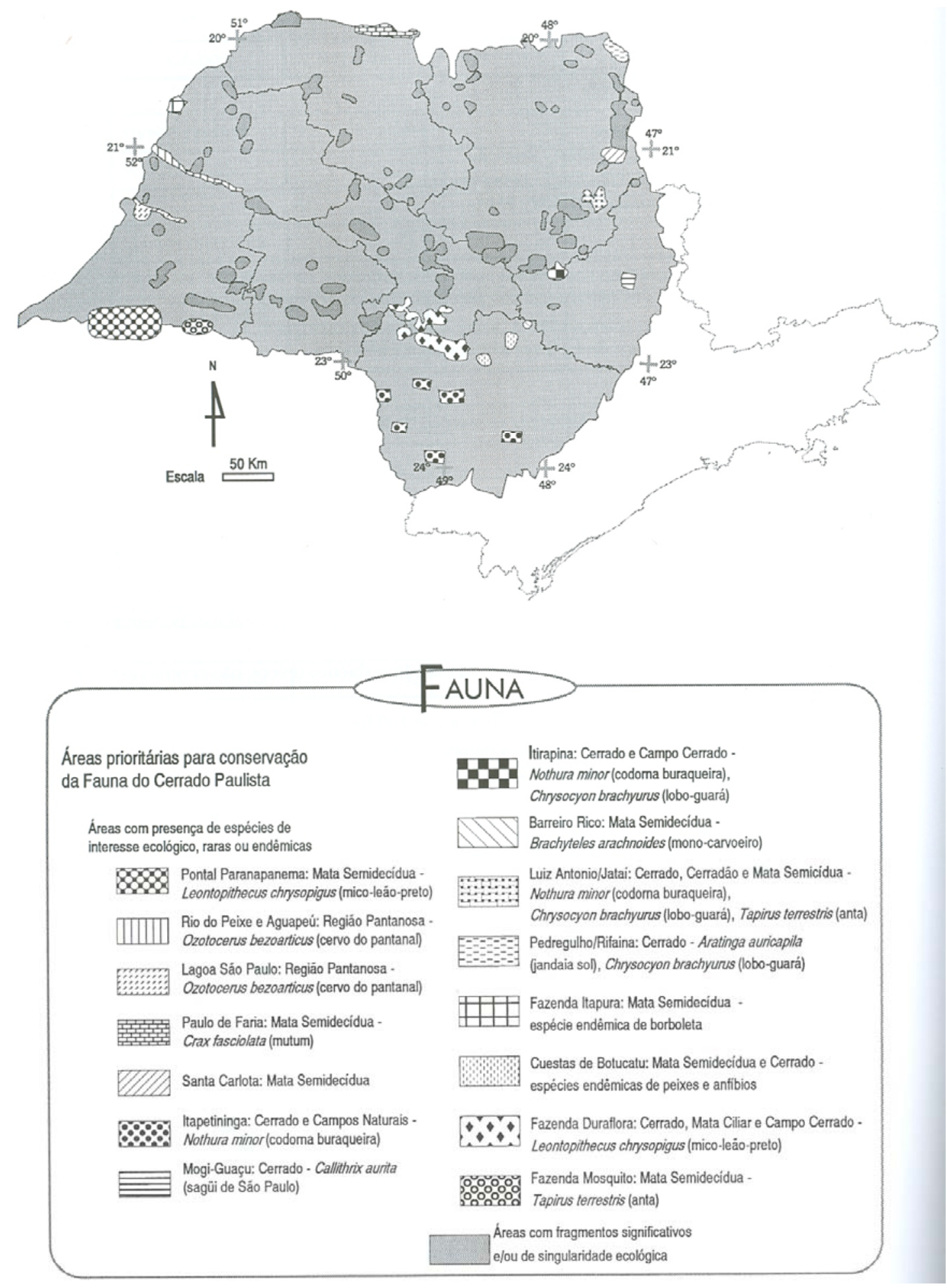

Figura 4: Localização de algumas espécies de animais ameaçadas de extinção no Estado de São

Paulo (Fonte: SEMA, 1997). 


\section{2. Área de Estudo:}

\subsection{Histórico:}

A A.R.I.E. (Área de Relevante Importância Ecológica) Cerrado Pé-de-Gigante fazia parte das terras da Usina Açucareira Vassununga, localizada no município de Santa Rita do Passa-Quatro -SP (figura 5). Em fins da década de 60, a usina entrou em falência, sendo devedora do Estado. O pagamento de suas dívidas foi efetuado em terras, tendo passado ao Estado quatro glebas contendo floresta mesófila semi-decídua com jequitibás (glebas Capão da Várzea, Capetinga, Praxedes e Maravilha) e uma outra gleba com vegetação de cerrado, a gleba Pé-de-Gigante (figura 6). Em 1970, estas cinco glebas vieram, através do Decreto $\mathrm{n}^{\circ}$ 52.546 de 26/10/70, a constituir o Parque Estadual do Vassununga, sob a responsabilidade do Instituto Florestal de São Paulo (Pivello, 1996).

Ao Estado, cabia ainda mais uma porção de terras, com aproximadamente 1000 ha, coberta com vegetação de cerrado e que seria destinada ao Instituto de Biociências da USP e se chamaria Reserva Mangaíba. Porém, devido a imprecisões na demarcação destas terras, o Estado nunca conseguiu registrar sua posse, apesar de muitas tentativas para sua correta delimitação.

Em 1971, o decreto $n^{\circ} 52.720$ datado de 12/3/71 incorpora ao Parque Estadual do Vassununga outra gleba, a Capetinga Leste (figura 5), e exclui a gleba Pé-de-Gigante, alegando que esta área de cerrado seria aquela destinada à USP para pesquisas ecológicas. Diante destas circunstâncias, a Universidade de São Paulo passou a requerer a área.

Em 1990, através do Decreto Federal n 99.275 ,datado de 06/06/90, foi criada a A.R.I.E. (Área de Relevante Interesse Ecológico) Cerrado Pé-de-Gigante, uma categoria provisória de unidade de conservação federal, a fim de assegurar seus recursos naturais. Em 1992, iniciaram-se negociações entre a USP e o governo do Estado, a fim de dar posse da área ao Instituto de Biociências da USP, a quem caberia a administração e fiscalização da área. Em 16 de abril de 1996, decidiu-se por uma gestão conjunta da área, a cargo tanto do Instituto de Biociências da USP como do Instituto Florestal da Secretaria de Meio Ambiente do Estado de São Paulo (Pivello, 1996). Esta decisão foi oficializada em julho de 1997, com o estabelecimento de um convênio entre o Instituto Florestal, ao qual cabe a parte de fiscalização e desenvolvimento de pesquisas na área, e a Universidade de São Paulo, que é responsável pelo desenvolvimento de pesquisas e atividades de educação ambiental. 
Atualmente, a gleba Cerrado Pé-de-Gigante voltou a fazer parte do Parque Estadual de Vassununga, mas continua sob a categoria de A.R.I.E. federal.

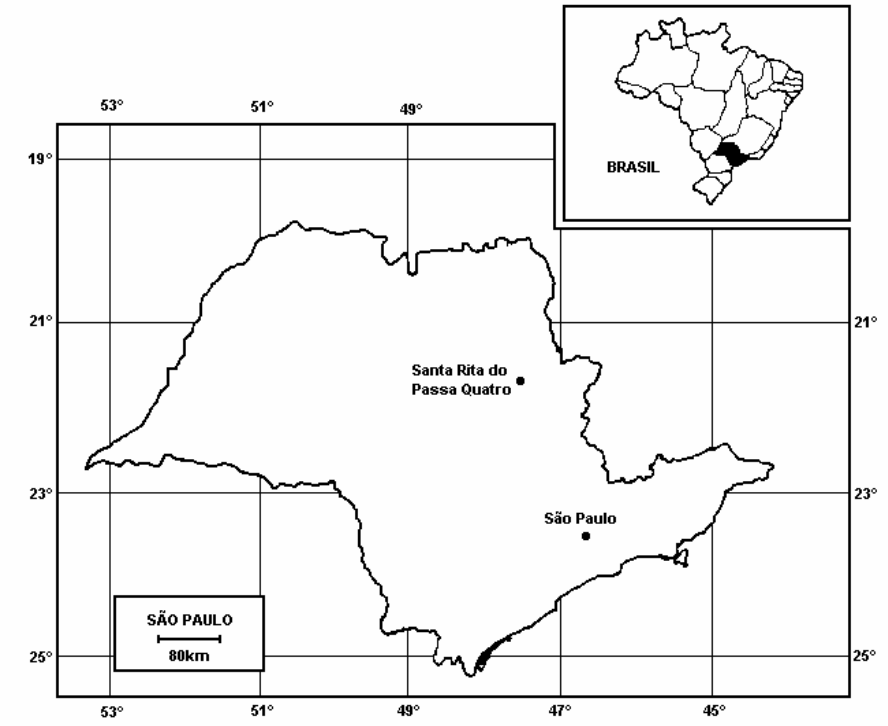

Figura 5 - Localização do município de Santa Rita do Passa Quatro no Estado de São Paulo,onde se encontra a A R.I.E. (modificado de Salis et al., 1995).

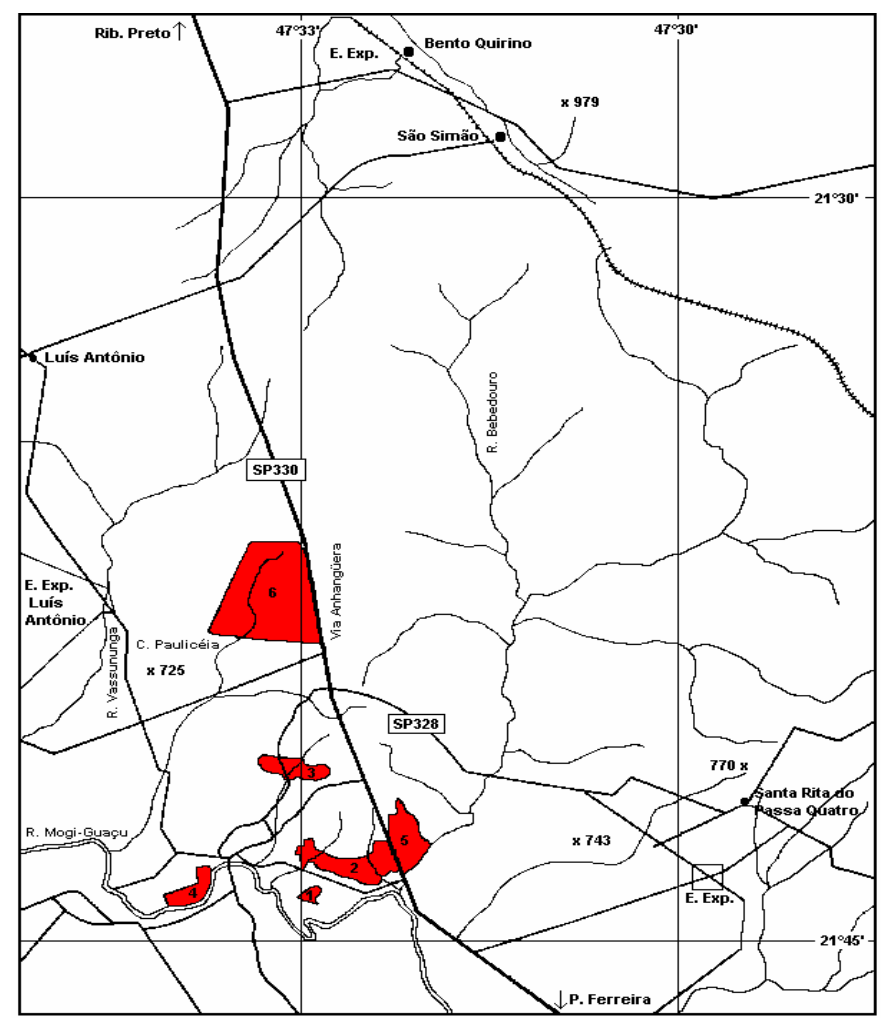

Figura 6 - Localização das glebas (1) Capão da Várzea, (2) Capetinga, (3) Praxedes, (4) Maravilha, (5) Capetinga Leste e (6) Pé-de-Gigante, pertencentes ao Parque Estadual do Vassununga, em Santa Rita do Passa Quatro, SP. 


\subsection{Caracterização da Área:}

A A.R.I.E. Cerrado Pé-de-Gigante localiza-se no município de Santa Rita do Passa-Quatro-SP, entre coordenadas aproximadas $21^{\circ} 36^{\prime}$ a $21^{\circ} 44^{\prime} \mathrm{S}$ e $47^{\circ} 34^{\prime}$ a $47^{\circ} 41^{\prime} \mathrm{W}$. Está às margens da rodovia Anhanguera (SP-330), entre os quilômetros 255 e 258. Possui aproximadamente 1225 ha de área, com altitudes que variam 590 a 740m (Mesquita Jr., 1988). O nome Pé-de-Gigante se deve a uma formação geomorfológica que se encontra em seu interior, sendo uma área rebaixada com aspecto de uma grande pegada (Castro, 1987) (figura 7).

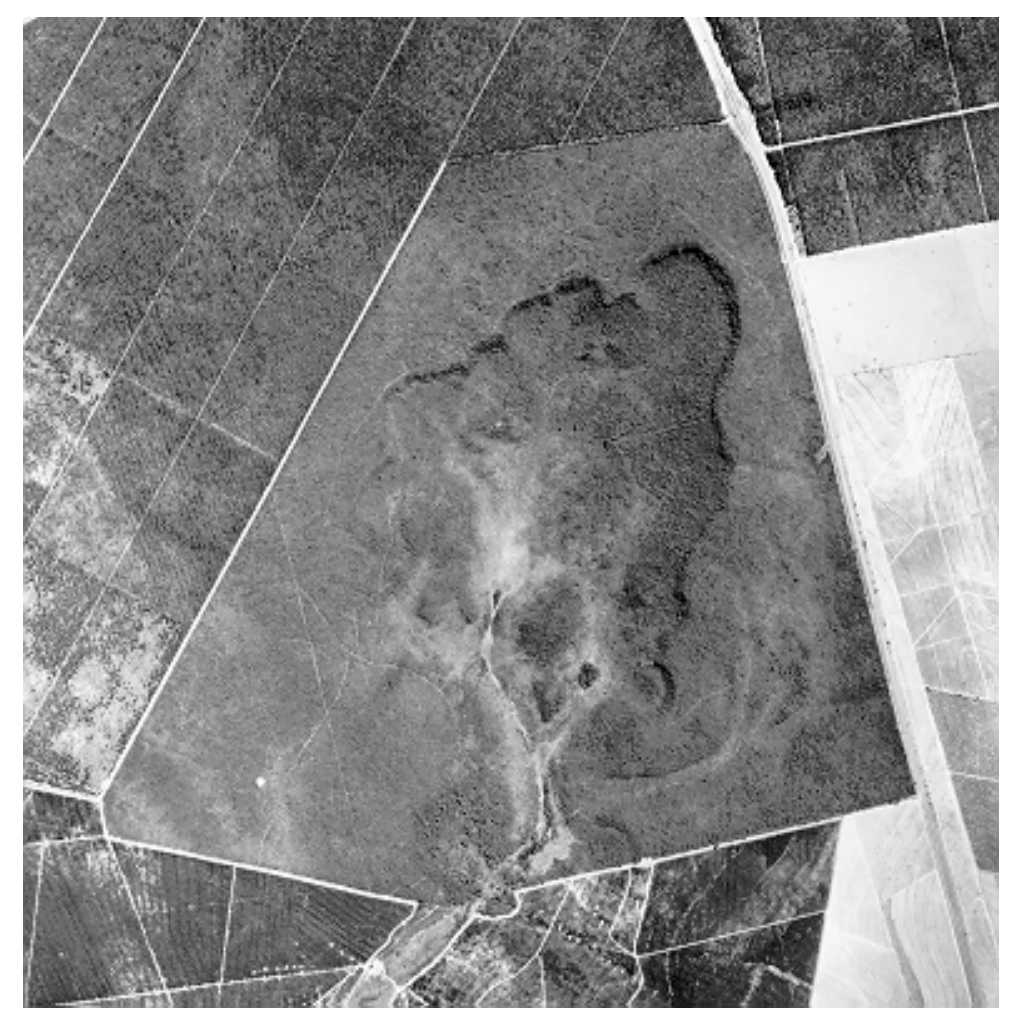

Figura 7 - Fotografia aérea (escala 1:40.000) da A.R.I.E. Cerrado Pé-de-Gigante, Santa Rita do PassaQuatro, SP $\left(21^{\circ} 36-44^{\prime} S\right.$ e $\left.47^{\circ} 34-41^{\prime} \mathrm{W}\right)$, em recobrimento aéreo realizado em 1988.

O clima regional, corresponde ao subtropical savânico (típico de zonobioma II) (Walter \& Lieth 1967), onde há uma estação seca de até 5 meses (maio a setembro) e uma chuvosa bem marcada,com temperaturas médias anuais entre 15 e $34^{\circ} \mathrm{C}$. A temperatura média nos meses de inverno (estação seca) vão de 15 a $31^{\circ} \mathrm{C}$ e nos meses mais quentes (estação 
úmida) de 20 a $34^{\circ} \mathrm{C}$. A pluviosidade anual é geralmente superior a $1400 \mathrm{~mm}$, com um período de precipitação mais intenso de outubro a março, com índices pluviométricos mensais superiores a $100 \mathrm{~mm}$ (figura 8 ).

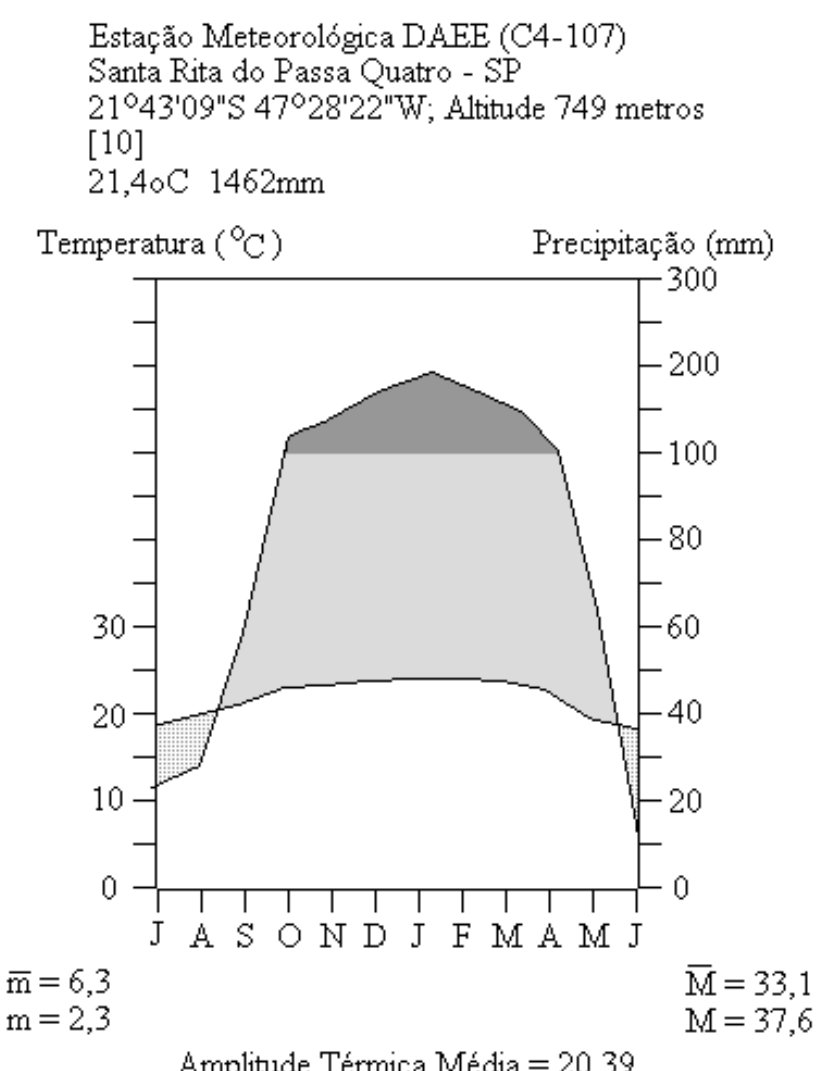

Figura 8: Diagrama climático segundo Walter \& Lieth para a A.R.I.E., construído com dados meteorológicos de1985 a 1994 da Estação Meteorológica do DAEE em Santa Rita do Passa-Quatro, SP (Fonte: Mesquita Jr., 1998).

De acordo com a carta geológica de superfície, produzida por Freitas 1986, toda a área compreendida pela A.R.I.E. encontra-se sobre a formação Santa Rita do PassaQuatro, com origem no Terciário, e provavelmente proveniente de depósitos aluvionares, constituída principalmente por areias finas (Almeida, 1974 apud Pivello, 1996).

Sua geomorfologia se insere na província da Depressão Periférica, na zona do Mogi-Guaçú, mas já muito próxima à província das Cuestas Basálticas (Almeida, 1974). O relevo caracteriza-se por formas suavizadas, levemente onduladas, constituídas por morros amplos (este é um sistema de relevo característico da província de Cuestas Basálticas, só ocorrendo na Depressão Periférica nesta região) , além de colinas médias, mais restritas, sendo enquadrado no grupo de relevos de degradação, onde predominam baixas declividades e amplitudes locais médias de 100 a 300m. A formação geológica do Pé-de-Gigante caracte- 
riza-se por ser uma cabeceira erosiva do córrego Paulicéia, que provocou o rebaixamento daquele terreno, formando uma grande pegada (Oliveira et al, 1982).

O solo da área apresenta-se bastante homogêneo dentro da A.R.I.E., classificado como Latossolo Vermelho Escuro, em associação ao Latossolo Vermelho Amarelo, ambos álicos, moderados ou fracos, de textura média. Estes solos predominam em toda região, sendo profundos, porosos e bem drenados, apresentando boas características físicas para o desenvolvimento radicular das plantas. São solos ácidos, com baixa capacidade de troca de cátions. Desta forma, apresentam limitações quanto o uso agrícola, relacionados à baixa fertilidade natural, mas podem ser aproveitados com o uso de fertilizantes e técnicas corretivas de acidez (Oliveira et al, 1982).

O fragmento da A.R.I.E. sofreu desmatamento, em função do cultivo de canade-açúcar e cítricos, além do pastoreio, até o ano de 1970. Após este período, entrou num processo progressivo de regeneração secundária. Esta regeneração natural formou mosaicos de vegetação, que podem representar diferentes etapas sucessionais, que variam em complexidade, indo de campo cerrado a cerradão, além da floresta estacional semidecídua e vegetação de várzea. Hoje, é totalmente cercado por monoculturas de eucalipto, cana-deaçúcar, e cítricos (Figura 9).

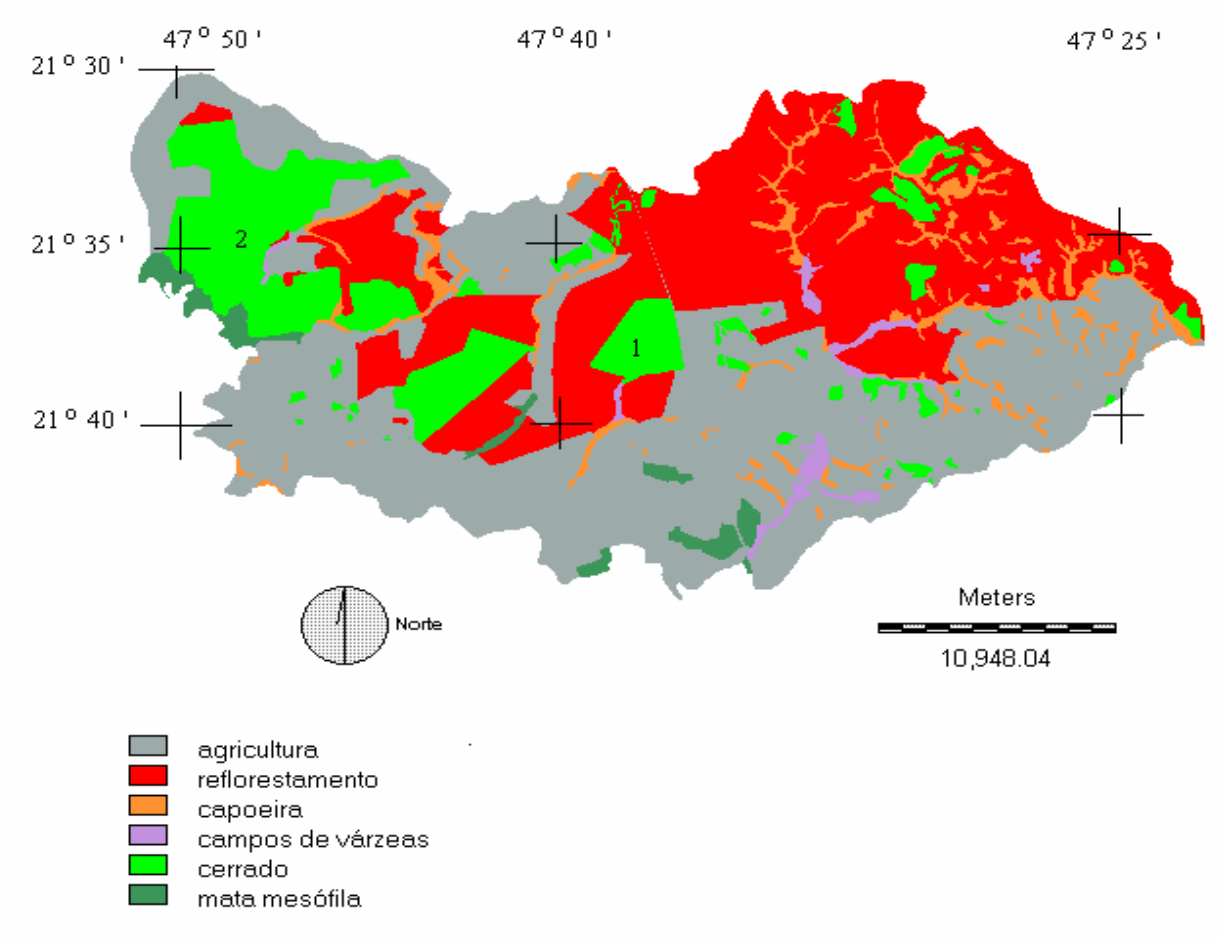

1- A.R.I.E. Cerrado Pé-de-Gigante

2- Estação Ecológica de Jataí

Figura 9: Uso das terras na região onde se encontra a A.R.I.E. Cerrado Pé-de-Gigante. (FONTE: Shida, C.N.in prep.) 


\section{Métodos:}

O estudo que aqui se apresenta engloba basicamente as seguintes etapas:

1) elaboração de um inventário dos mamíferos de médio e grande porte da A.R.I.E. Cerrado Péde-Gigante;

2) elaboração de um inventário dos pequenos mamíferos da A.R.I.E.;

3) caracterização de cada uma das fisionomias de cerrado amostradas, relacionando-as com a ocorrência dos mamíferos;

4) realização de um levantamento histórico da fauna regional.

A metodologia empregada na realização destas etapas encontra-se descrita a seguir.

\subsection{Mamíferos de Médio e Grande Porte:}

Para o inventário dos mamíferos de médio e grande porte, as campanhas de campo iniciaram-se em setembro de 1996 e se prolongaram até março de 1998, quando se observou indícios, como as fezes, pegadas e rastros encontrados nas diferentes áreas amostradas (figura 10), que foram devidamente identificadas e fotografadas. Algumas fezes foram coletadas e houve também a observação direta de vários animais. Para facilitar a visualização de pegadas, construiu-se, em cada uma das áreas amostradas, um canteiro de areia lavada de aproximadamente $2 \mathrm{~m}^{2}$ ao longo da trilhas utilizadas neste estudo (figura 11). 


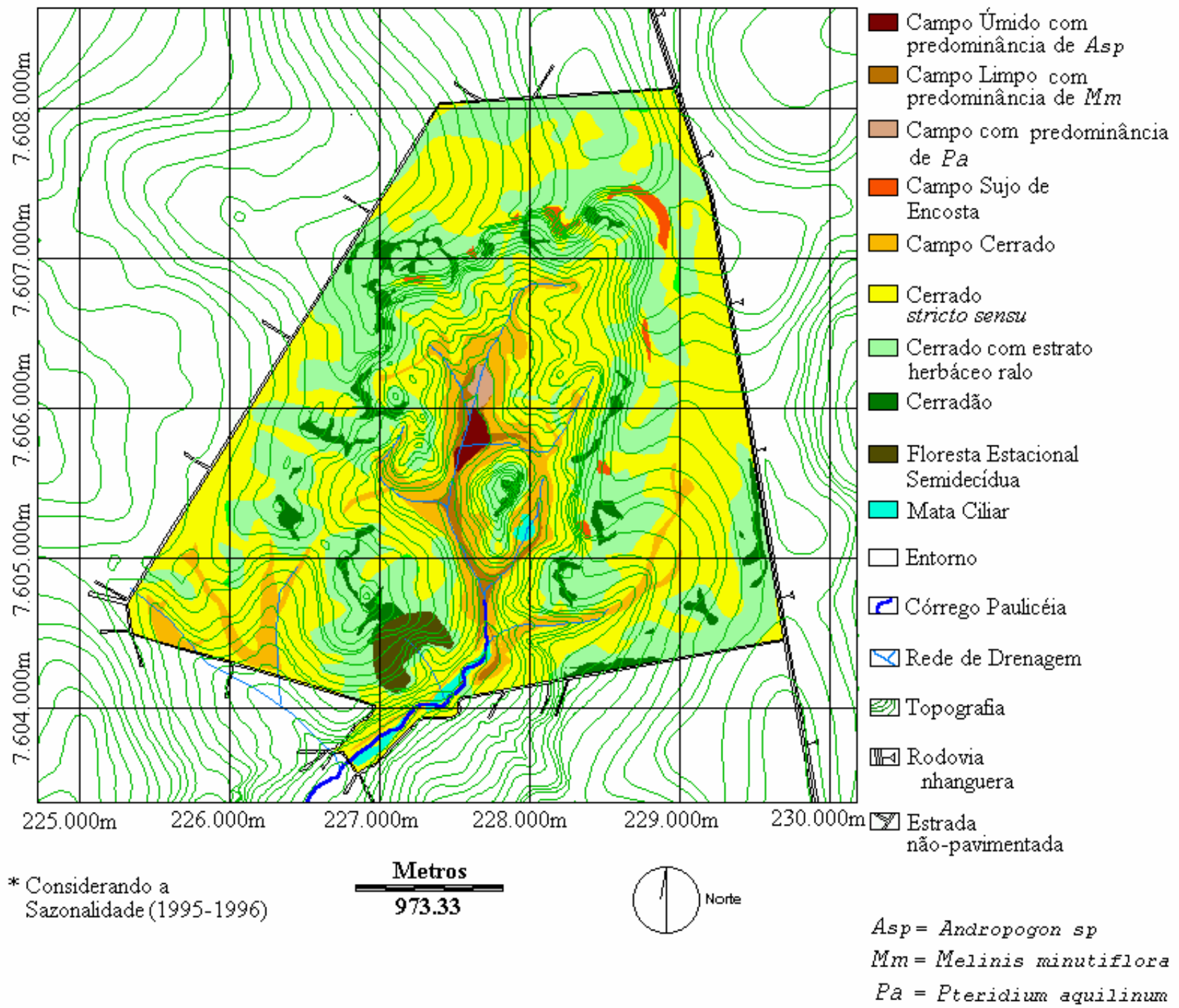

Figura10: Localização das fitofisionomias e o circuito utilizado para amostragem de mamíferos na A .R.I.E.. Cerrado Pé-de-Gigante (segundo Mesquita Jr.,1998). 


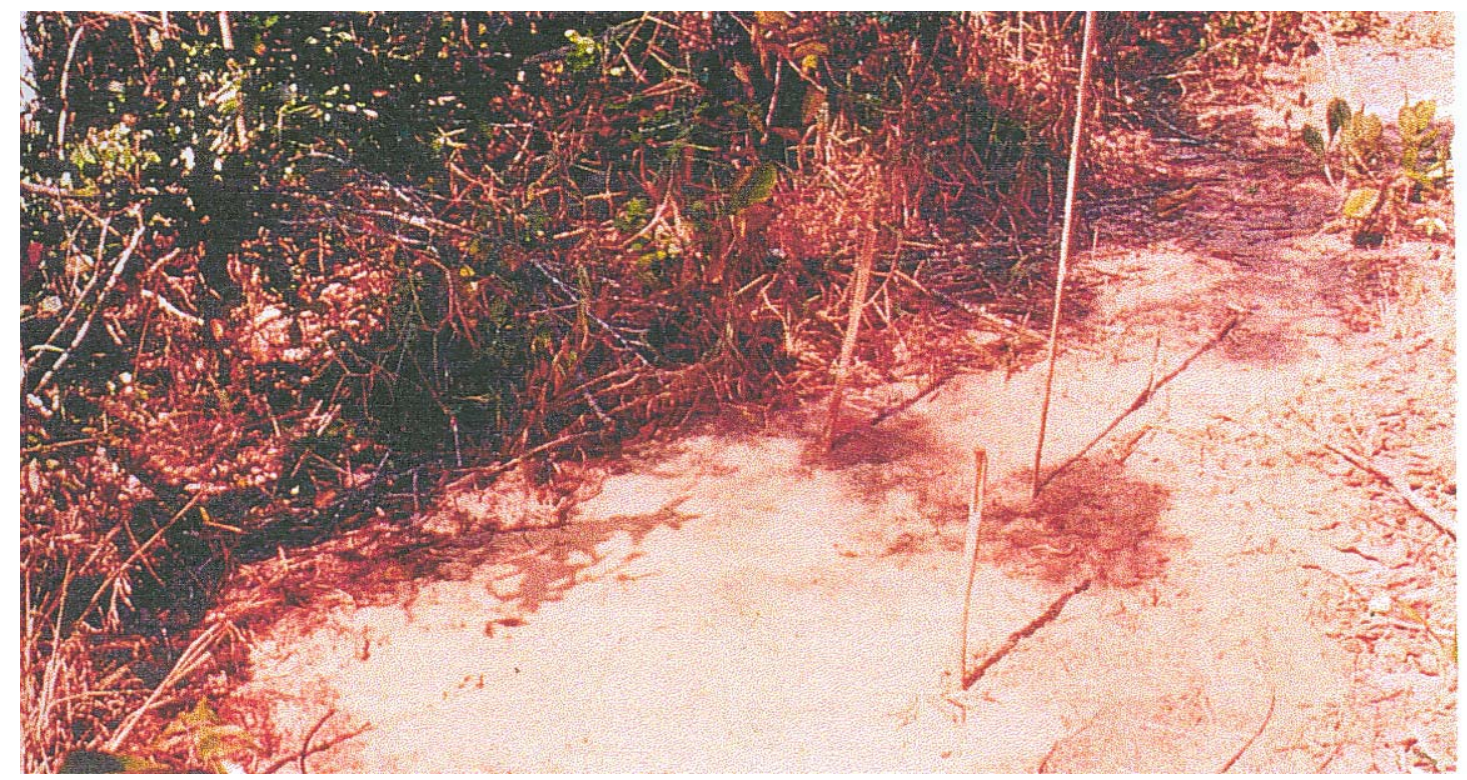

Figura 11: Canteiro de areia utilizado para verificação de pegadas de mamíferos de médio e grande porte.

\subsection{Pequenos Mamíferos:}

Para o estudo de pequenos mamíferos, realizaram-se campanhas de campo, com a duração de três dias consecutivos por mês, que se iniciaram em abril de 1997 e findaram em março de 1998, quando se completou 12 meses de coleta.

Foram amostradas 5 diferentes fisionomias de cerrado e uma floresta homogênea de eucaliptos. A captura dos pequenos mamíferos* ${ }^{*}$ baseou-se na bibliografia de Wilson et al. (1996), e utilizou-se dois tipos de armadilhas: do tipo gaiola convencional e do tipo pitfall. Cada uma das áreas amostradas possuía 17 armadilhas do tipo gaiola (figura 12), dispostas a cada $25 \mathrm{~m}$, acompanhando a trilha (figura 10 ). 


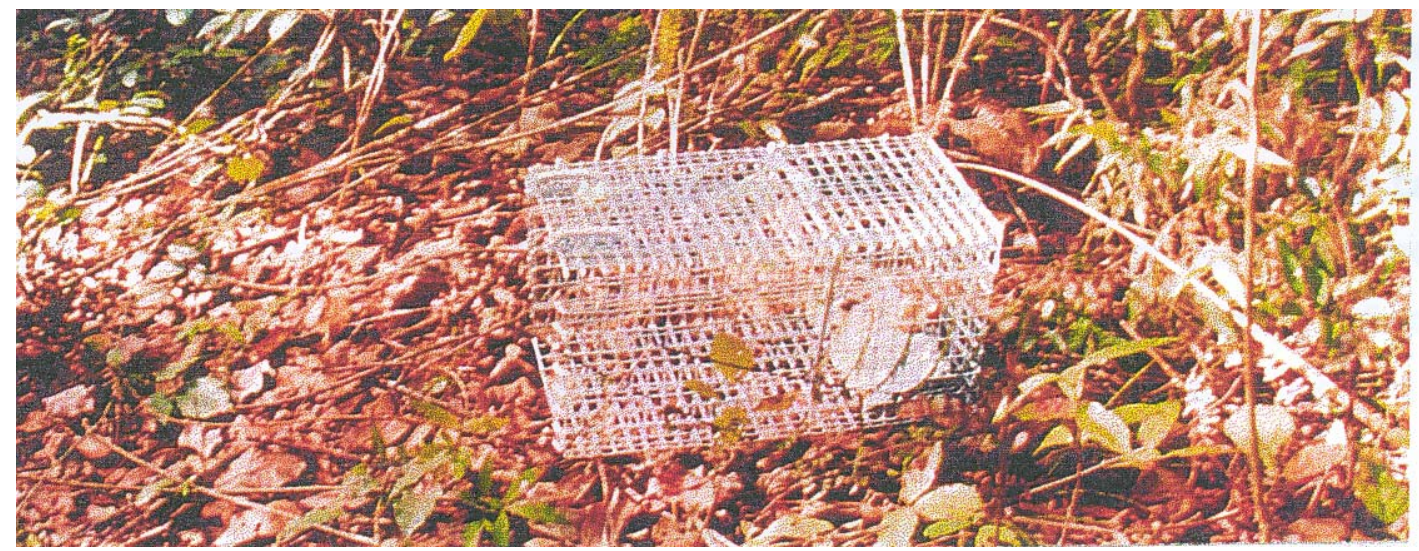

Figura 12: Armadilha do tipo gaiola utilizada na captura de pequenos mamíferos

Estas gaiolas eram armadas um dia antes do início da campanha de campo e revisadas todos os dias pela manhã. A isca utilizada era composta por uma mistura de paçoca de amendoim, sardinha, fubá, banana e ração peletizada, espalhadas em cima de uma rodela de mandioca. Experimentou-se, além da mandioca, milho, abóbora, e banana, porém, o primeiro apresentou melhores resultados. Existia também em cada uma das áreas amostradas um estação de pitfall, com 4 baldes, de $40 \mathrm{~cm}$, enterrados, unidos por uma lona plástica de $45 \mathrm{~cm}$ de altura por $4 \mathrm{~m}$ de comprimento, formando uma estrela de três pontas, conforme mostra a figura 13.

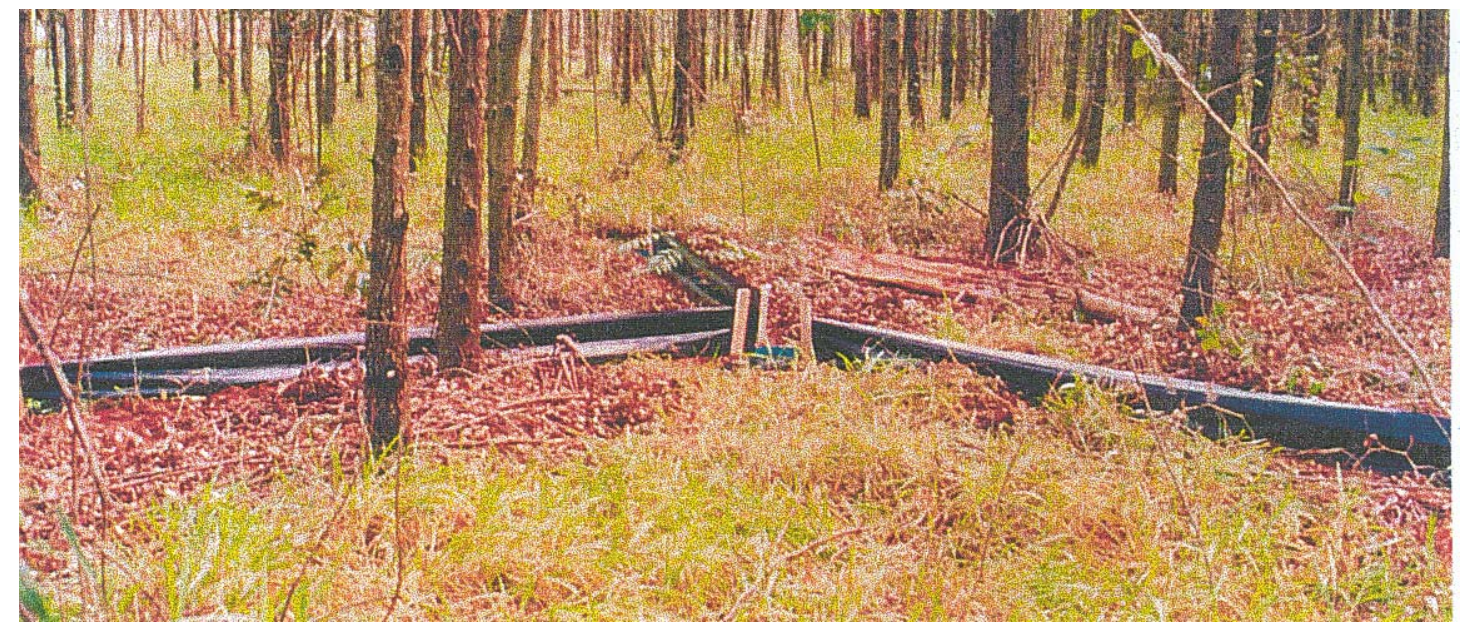

Figura 13: Estação de pitfall para coleta de pequenos mamíferos. 
Os baldes do pitfall eram destampados também um dia antes do início da campanha de campo, e revisados todas as manhãs.

O estudo dos pequenos mamíferos constava de um programa de capturamarcação-recaptura (utilizando-se de um pique na orelha do animal) e, para cada indivíduo capturado, foram anotadas as seguintes informações: 1) espécie, 2) localização (fisionomia vegetal), medidas morfométricas (corpo, cauda e pata traseira). Os indivíduos eram identificados através da coleção de referência do Museu de Zoologia da USP - SP, com o auxílio do Prof. Dr. Mário de Vivo (Laboratório de Zoologia, Universidade de São Paulo, Campus de Ribeirão Preto).

Os animais capturados vivos eram encaminhados à equipe da Profa. Dra. Yatyio Yassuda (Laboratório de Citogenética de Vertebrados, Universidade de São Paulo, campus de São Paulo) para sua identificação cromossômica, e então taxidermizados e enviados ao Museu de Zoologia da Universidade de São Paulo. Os animais que morriam em campo foram formolizados e também enviados ao Laboratório de Zoologia da USP - Campus de Ribeirão Preto.

Para a taxidermização, retirou-se a pele do animal morto, através de um pe-queno corte na região ventral, espalhou-se borax por toda sua extensão interna, preencheu-se a pele com chumaços de algodão e, finalmente, costurou-se o corte da região ventral. (Dr. Mário de Vivo com. pess.) (figura 14).

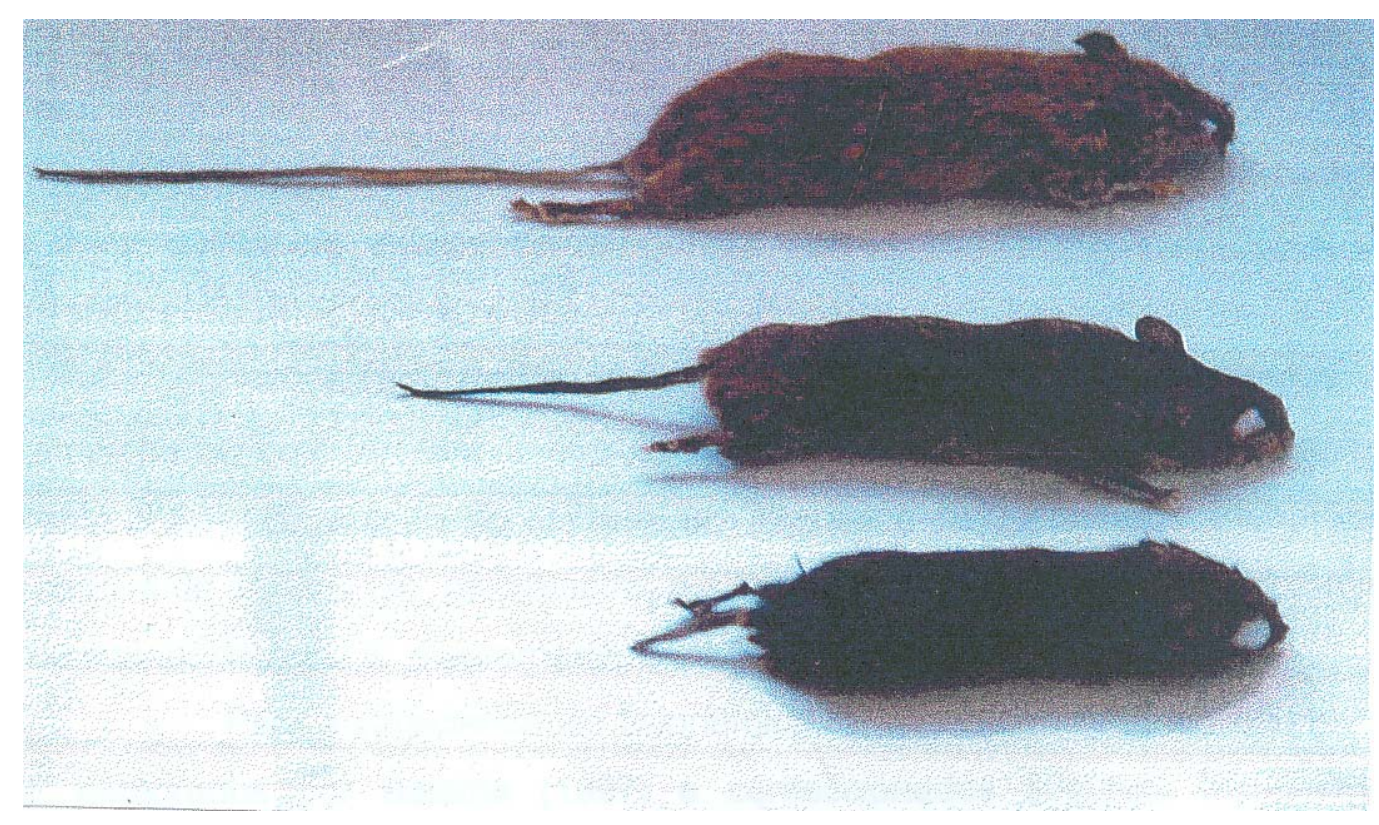

Figura 14: Roedores taxidermizados. 


\subsection{Caracterização dos Habitats:}

Para a localização dos diferentes habitas amostrados na A.R.I.E. Cerrado Péde-Gigante, utilizou-se o mapa de fitofisionomias elaborado por Mesquita Jr. (1998), que se baseou em imagens de satélite LANDSAT - TM (anos de 1996, estação seca e 1997, estação chuvosa). As imagens de satélite foram trabalhads em um sistema de informação geográfica (IDRISI - versão 4.1).

A caracterização pontual dos habitats amostrados baseou-se em dados principalmente qualitativos e foi feita com o intuito de se comparar suas potencialidades quanto ao suporte para a mastofauna. Foram consideradas variáveis físicas e biológicas, avaliadas em cada estação de coleta.

A caracterização física dos habitats constituiu-se de uma análise localizada do solo e inclinação do terreno, identificada em carta topográfica detalhada (Mesquita Jr., 1997). A cobertura do solo por matéria vegetal viva, foi estimada através de uma escala arbitrária ( $0=$ não há; $1=$ pouco; 2= médio; $3=$ muito). Estimou-se o tipo de solo e seu grau de compactação através de análise morfológica, segundo Souza (1995). A compactação do solo foi também identificada por meio da mesma escala arbitrária ( $0=$ não há; $1=$ pouco; $2=$ médio; $3=$ muito), bem como a presença de folhedo sobre o solo e a estratificação herbácea.

Foi também observada no solo a presença de cupinzeiros, formigueiros e buracos de tatu, que podem oferecer recursos alimentares e abrigo para alguns exemplares da fauna local.

A distância do local de amostragem ao eixo de drenagem corresponde à distância linear obtida em análise de fotografias aéreas, na escala 1:25.000, e calculada através do software IDRISI, versão 4.1 .

Para a comparação microclimática entre os habitats amostrados, mediu-se a temperatura do ar, com um termômetro de mercúrio $\left({ }^{\circ} \mathrm{C}\right)$, tanto na fisionomia amostrada e externamente à A.R.I.E., à beira da estrada, em intervalos de 30 minutos. Foram medidas a umidade relativa do ar, com um psicrômetro, e a intensidade luminosa com um fotômetro (lux), também no interior da A.R.I.E. e externamente a ela, em intervalos de 30 minutos.

Para a caracterização fisionômica da vegetação local, utilizou-se os perfisdiagrama, elaborados por Batalha (1997) e confeccionados segundo Muller-Dombois \& Ellenberg (1974). A quantificação da cobertura oferecida pelos estratos arbóreos e/ou arbustivos foi medida com um densiômetro convexo (Lemmon, 1957). Foi avaliado também o número de estratos vegetacionais presentes. 
As principais perturbações antropogênicas no interior e às margens da A.R.I.E. foram identificadas e localizadas, com o auxílio de um GPS, durante percursos aleatórios e plotadas sobre uma carta topográfica.

\subsection{Levantamento histórico da fauna:}

Para a obtenção de informações históricas sobre a fauna regional, foi idealizada uma série de entrevistas a 19 pessoas que residem na região e conhecem a região da A.R.I.E. Cerrado Pé-de-Gigante há muitos anos. Para tanto, utilizou-se de um questionário com 12 questões abertas, pré-elaborado segundo Byerlee et al (1980) (anexo 1). As entrevistas foram dirigidas da forma mais natural possível, procurando não constranger, inibir ou sugestionar o entrevistado.

Foram também verificadas as reintroduções de animais nativos na região, através de registros do Instituto Florestal da Secretaria do Meio Ambiente do Estado de São Paulo, desde a década de 80 até os dias atuais. Para tanto, pesquisou-se os documentos expedidos pela Polícia Florestal, disponíveis na sede administrativa da Estação Ecológica de Jataí, Luiz Antônio - SP.

\subsection{Tratamento Estatístico:}

O esforço de captura para cada tipo de armadilha foi avaliado da seguinte forma: a) para as capturas com o uso de gaiola, o esforço traduziu-se em trapnights, ou seja, o número de armadilhas $x$ número de noites em que elas permaneceram abertas em cada área, b) para as capturas em pitfalls, o esforço foi medido em estações/dia, ou seja, número de estações de pitfall x o número de dias em que elas permaneceram abertas em cada área.

A fim de se obter a média das medidas corpóreas dos pequenos mamíferos, foram calculadas as médias $(X)$ e o seu desvio padrão $(\delta)$ para cada uma das espécies capturadas, dos parâmetros: corpo, cauda e pata traseira.

O índice de diversidade de Shannon-Wiener (Krebs, 1989) foi utilizado para avaliar a diversidade de pequenos mamíferos em cada uma das fisionomias amostradas, 
calculado com o logarítmo na base 2, utilizando-se o programa MVSP (shareware) $: H^{\prime}=-\sum \mathrm{p}_{\mathrm{i}} \times \log _{2}$ $\mathrm{p}_{\mathrm{i}}$.

Para se comparar a eficiência de captura entre os dois diferentes tipos de armadilhas (gaiola e pitfall), utilizou-se o índice de similaridade de Jaccard - Isj (Krebs, 1989) :

Isj $\%=\frac{n^{\circ} \text { de espécies comuns a A e B }}{n^{\circ} \text { de espécies de } A+n^{\circ} \text { de espécies de B - } n^{\circ} \text { de espécies comuns }} \times 100$

Utilizou-se a análise de agrupamento (Krebs, 1989) para comparar as diferentes fisionomias, com relação à oferta de habitats à mastofauna, através do programa MVSP (shareware). Esta análise baseou-se em matrizes de distância euclidiana, através do método do vizinho mais próximo, tanto com relação à ocorrência de pequenos mamíferos em cada fisionomia (animais capturados $\mathrm{X}$ fisionomias), como para as características ambientais de cada uma delas (altura das árvores, $n^{\circ}$ de estratos vegetacionais, tipo de solo, densidade foliar, quantidade de plantas exóticas, disponibilidade de recursos alimentares).

A fim de relacionar as diferentes fisionomias vegetais e as espécies de pequenos mamíferos que ocorriam em cada delas, fez-se uma análise de correspondência (CA) (Pielou, 1984), utilizando-se o programa MVSP (shareware), com o alogarítimo da média recíproca.

Uma análise de correlação bivariada não-paramétrica foi realizada para reforçar os resultados conseguidos na análise de correspondência, através do método de Spearman (Zar, 1999). 


\section{Resultados:}

\subsection{Mamíferos de médio e grande porte:}

O registro dos mamíferos de médio e grande porte, constatados indiretamente por meio de pegadas, fezes, tocas, vocalização, rastros, e diretamente no meio de avistamentos encontram-se na tabela 1 e nas figuras 15 e 16.

Tabela 1: Ocorrência dos mamíferos de médio e grande porte nas diferentes fisionomias vegetais. $(E S=$ estrada, $F R=$ floresta ripária, $\mathrm{CU}=$ campo úmido, $\mathrm{EU}=$ eucalipto, $\mathrm{CC}=$ campo cerrado, $\mathrm{CS}=$ cerrado "sensu stricto", $\mathrm{FSD}=$ floresta semidecídua. $A$ = avistamento, $B=$ pegadas, $C=$ fezes, $D=$ buracos/tocas/ninhos, $E=$ morto, $F=$ vocalização. * duas espécies de Mazama sp)

\begin{tabular}{|l|l|l|l|l|l|l|l|}
\hline & ES & FR & CU & CC & CS & FSD & EU \\
\hline Dasypus sp & $1 \mathrm{E}$ & $1 \mathrm{D}, 3 \mathrm{~B}, 6 \mathrm{D}$ & $3 \mathrm{D}$ & $1 \mathrm{D}$ & $3 \mathrm{D}$ & $1 \mathrm{D}$ & $5 \mathrm{C}$ \\
\hline Felis sp & & $2 \mathrm{C}, 1 \mathrm{~B}$ & $1 \mathrm{C}$ & & $2 \mathrm{C}$ & & $11 \mathrm{~B}, 2 \mathrm{C}$ \\
\hline Mazama sp * & & $7 \mathrm{~B}$ & $1 \mathrm{~B}, 1 \mathrm{~A}$ & $2 \mathrm{~B}$ & $1 \mathrm{~A}, 6 \mathrm{~B}$ & $1 \mathrm{~B}$ & $12 \mathrm{~A}, 15 \mathrm{~B}, 1 \mathrm{C}$ \\
\hline Dusycion thous & & & & & & & $2 \mathrm{~A}, 6 \mathrm{~B}$ \\
\hline Felis concolor & $1 \mathrm{E}$ & & & & $1 \mathrm{~B}, 1 \mathrm{C}$ & & $7 \mathrm{~B}$ \\
\hline Chrysocyon brachyurus & $2 \mathrm{E}$ & $2 \mathrm{~B}$ & $1 \mathrm{~A}, 3 \mathrm{C}$ & & $5 \mathrm{~B}$ & & $6 \mathrm{~A}, 18 \mathrm{~B}$ \\
\hline Hidrochaeris hidrochaeris & & $2 \mathrm{~B}$ & $2 \mathrm{~B}$ & & & & $2 \mathrm{~B}, 1 \mathrm{C}$ \\
\hline Dasyprocta sp & & $1 \mathrm{~A}, 5 \mathrm{~B}$ & $1 \mathrm{~B}$ & $1 \mathrm{~A}$ & $1 \mathrm{~A}, 1 \mathrm{~B}$ & & $1 \mathrm{~A}, 6 \mathrm{~B}, 1 \mathrm{C}$ \\
\hline Eira barbara & & & & & $1 \mathrm{~A}$ & & $3 \mathrm{~A}, 5 \mathrm{~B}$ \\
\hline Agouti paca & & $1 \mathrm{~B}$ & & & & & $1 \mathrm{~A}$ \\
\hline Sylvilagus brasiliensis & & $1 \mathrm{~B}$ & & & & & $2 \mathrm{~A}$ \\
\hline Tamandua tetradactyla & $1 \mathrm{E}$ & & & $1 \mathrm{~A}$ & $1 \mathrm{~B}$ & & \\
\hline Myrmecophaga tridactyla & & & & & & & $2 \mathrm{~A}, 5 \mathrm{~B}$ \\
\hline Allouatta caraya & & & & & & $2 \mathrm{~A}$ & \\
\hline Dasypus novemcinctus & $2 \mathrm{E}$ & $1 \mathrm{~B}$ & & $5 \mathrm{~B}$ & $5 \mathrm{~B}$ & & $6 \mathrm{~B}$ \\
\hline Conepatus chinga & & & & & & & $2 \mathrm{~B}$ \\
\hline Nasua nasua & & & & & & & $1 \mathrm{~A}$ \\
\hline Callicebus personatus & & $2 \mathrm{~F}$ & & & & & \\
\hline Cebus apella & & $1 \mathrm{~A}$ & & & & & \\
\hline Sphigurus villosus & & & & & & & $1 \mathrm{~B}, 1 \mathrm{C}$ \\
\hline Procyon cancrivorus & & & & & & $1 \mathrm{~A}$ \\
\hline Cavia sp & & & & & \\
\hline
\end{tabular}




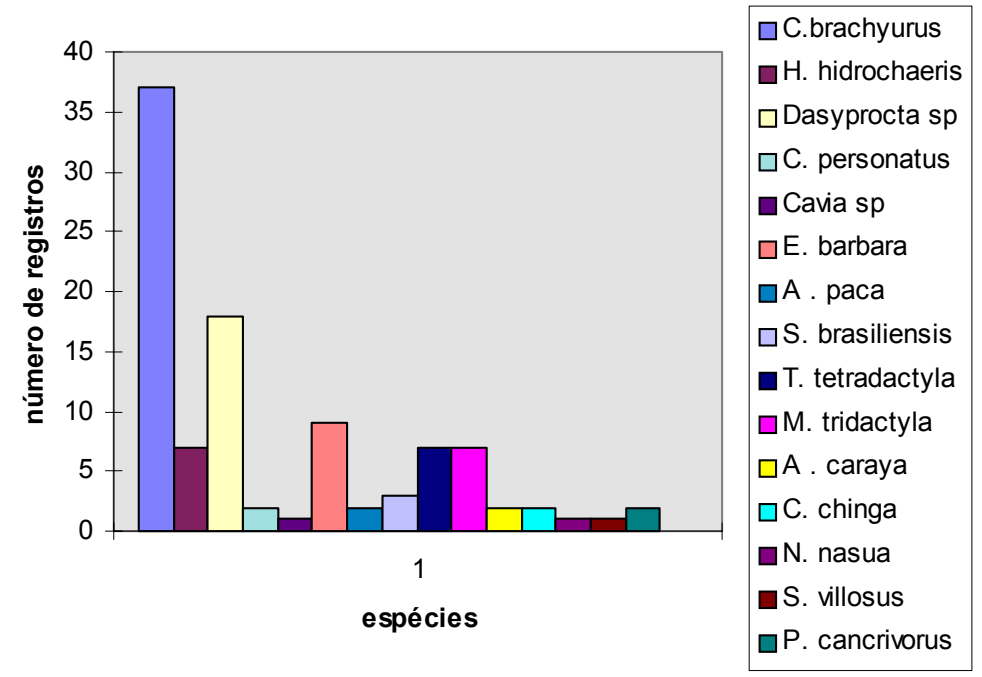

Figura 15: Frequência de ocorrência dos mamíferos de médio e grande porte, detectados através de avistamentos, fezes e pegadas.

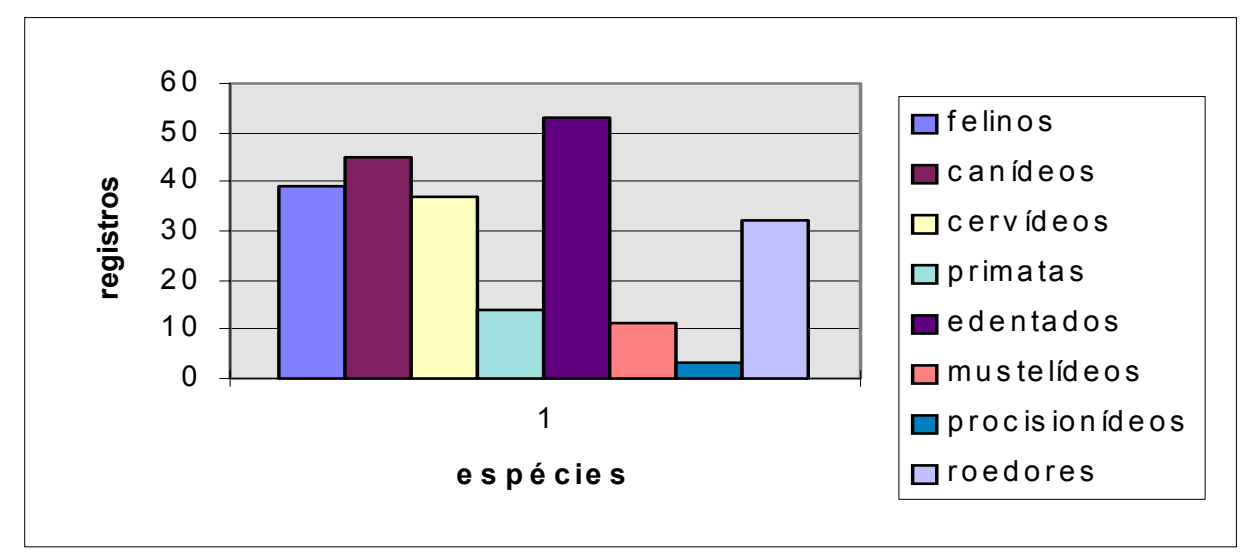

Figura 16: Grupos de animais de médio e grande porte registrados na A.R.I.E.

O gênero Mazama foi o mais frequente. Ocorrem na região duas espécies de veados deste gênero, o $M$. americana e o $M$. guazoubira, que não foram diferenciados, principalmente, na coleta dos dados indiretos (pegadas e fezes) (figuras 17 e 18). Estes animais encontravam-se frequentemente nas estradas de terra, entre os talhões do reflorestamento e pastando no sub-bosque da monocultura de eucalipto; ocasionalmente, eram avistados na monocultura de cana-de-açúcar, alimentando-se de brotos novos. O contato destes animais com herbicidas, pesticidas e fertilizantes era certo e frequente. 


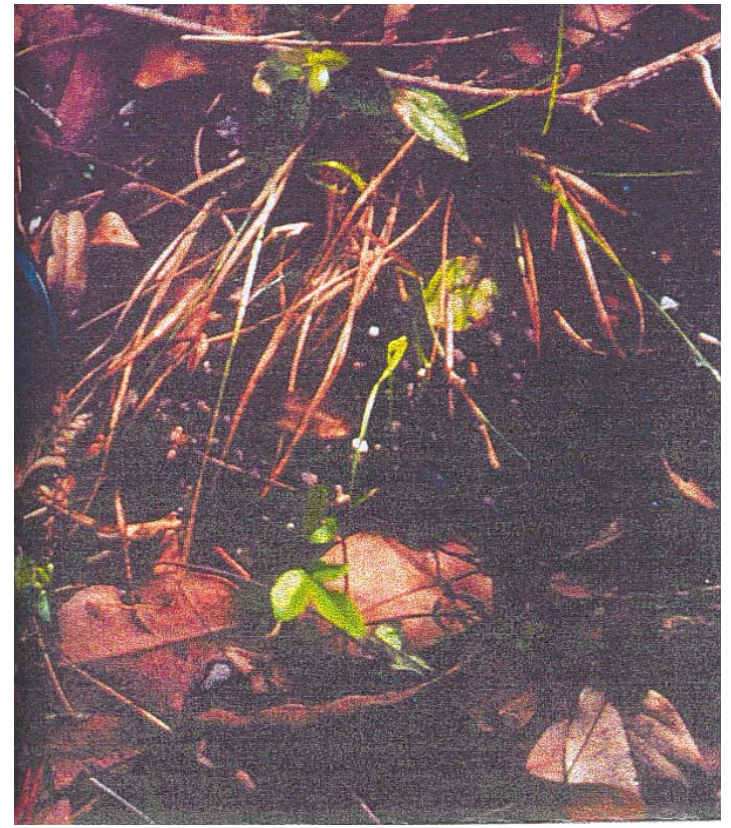

Figura 17: Fezes de Mazama sp

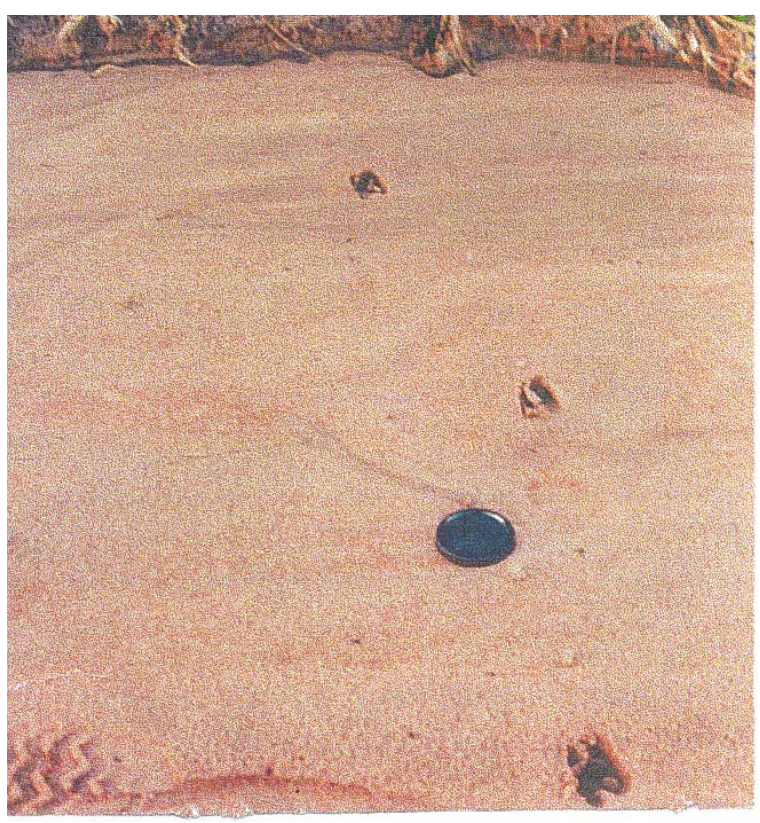

Figura 18: Pegadas de Mazanma sp

Indivíduos da espécie Chrysocyon brachyurus, o lobo-guará, foram também bastante frequentes (figuras 19 e 20). A exemplo de Mazama sp, sua ocorrência se deu principalmente nas estradas de terra e nas monoculturas de eucalipto, as quais eles pareciam utilizar somente como passagem entre outras áreas. Também pareciam ser muito atraídos pela movimentação dos funcionários das empresas de reflorestamento durante o perído de corte da madeira (aproximadamente 3 meses), que habitualmente deixavam restos de comida nas imediações da A.R.I.E., para atraí-los. Foram avistados indivíduos sozinhos, casais e fêmeas com filhotes. Um exemplar de Chrysocyon brachyurus foi encontrado atropelado na Via Anhanguera, exatamente defronte à A.R.I.E. (figura 21). 


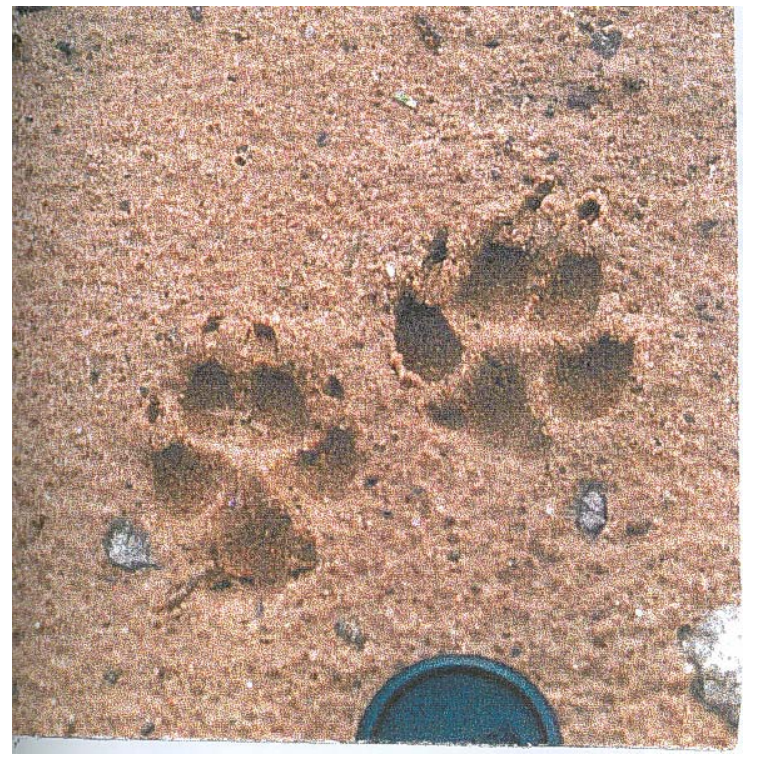

Figura19: Pegadas de Chrysocyon brachyurus.

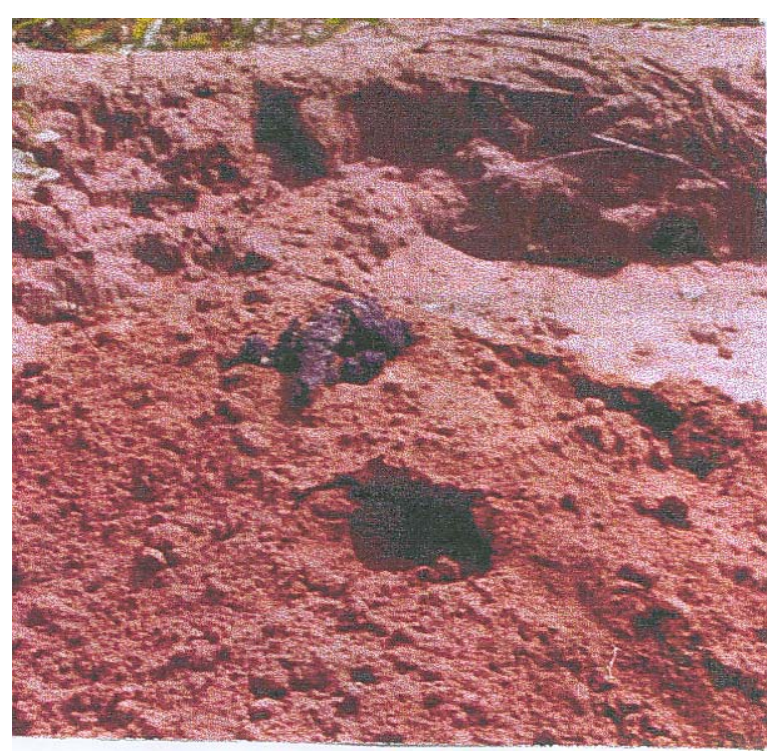

Figura 20: Fezes de Chrysocyon brachyurus.

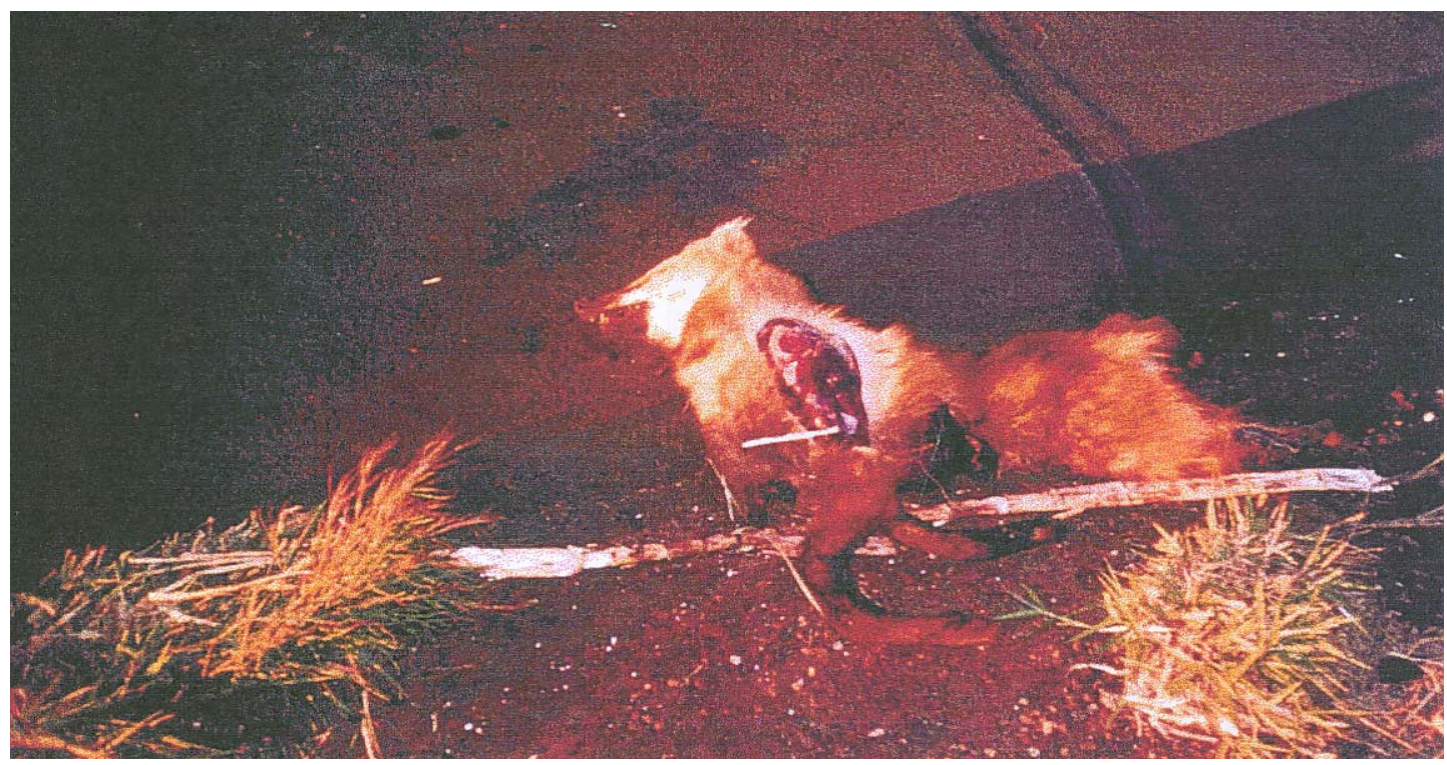

Figura 21: Exemplar de Chrysocyon brachyurus encontrado atropelado na Via Anhanguera defronte à A.R.I.E. Cerrado Pé-de-Gigante.

Dos primatas encontrados, a maior ocorrência foi da espécie Cebus apella, o macaco-prego, que foi avistada várias vezes, em grupos grandes, com 10 indivíduos em média, cruzando a estrada de terra, entre os eucaliptos e a A.R.I.E.

A ocorrência da espécie Felis concolor, a onça-parda, foi detectada apenas de maneira indireta (pegadas, fezes, etc) (figura 22). Encontrou-se vestígios do felino tanto 
dentro da Reserva como nas estradas de terra e na monocultura de eucalipto. Dentro da A.R.I.E., encontrou-se inclusive uma carcaça de tatu que havia sido caçada e devorada por um indivíduo de Felis concolor, provavelmente, no dia anterior à campanha de campo (figura 23). Funcionários das empresas de reflorestamento relataram vários avistamentos desta espécie, inclusive de uma fêmea com filhote. Um indivíduo atropelado foi encontrado na estrada asfaltada que ligava a cidade de Luiz Antônio à rodovia Anhanguera.

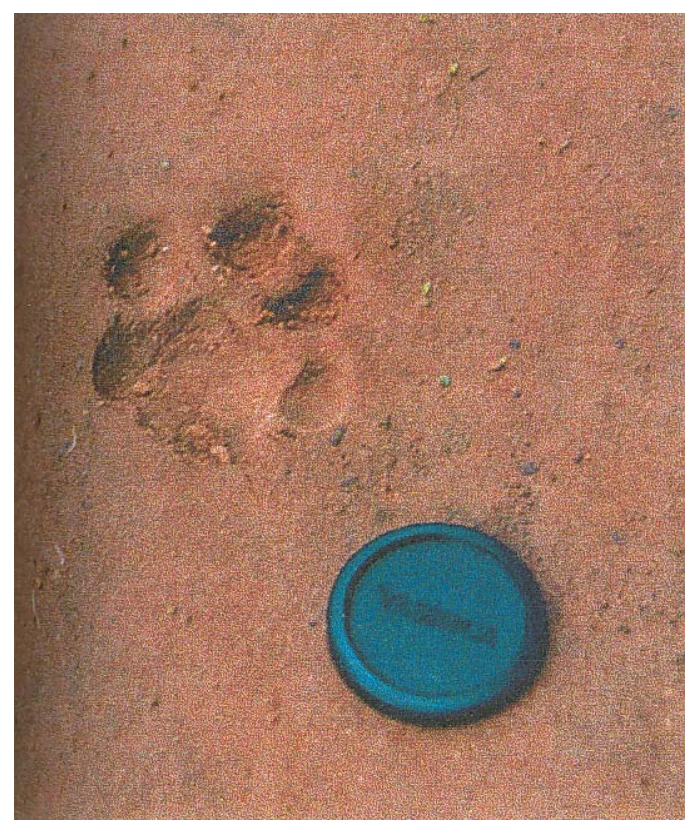

Figura 22: Pegada de Felis concolor.

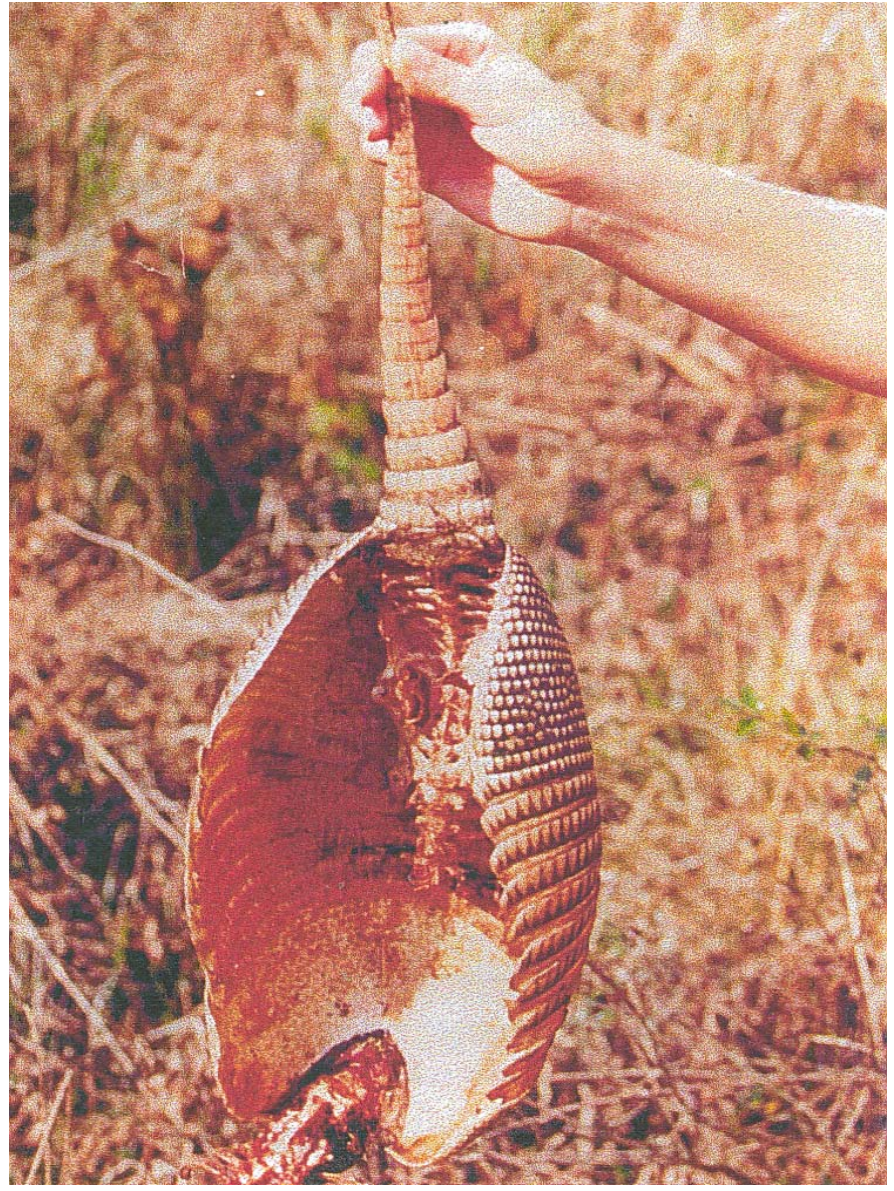

Figura 23: Carcaça de tatu caçado por um indivíduo de Felis concolor.

Indivíduos das espécies Myrmecophaga tridactyla, o tamanduá-bandeira, e Tamandua tetradactyla, o tamanduá-mirim, ocorreram principalmente no interior da A.R.I.E., apesar de terem sido avistados um indivíduo de $M$. tridactyla na estrada de terra e um atropelado na Via Anhanguera, defronte à A.R.I.E. Cerrado Pé-de-Giagante. Os únicos 
indivíduos de Dusicyon thous, o cachorro-do-mato, avistados foram um casal na monocultura de cana-de-açúcar contígua à A.R.I.E. (figura 24).

Os demais indícios de mamíferos de médio e grande porte, como os de Felis $\mathrm{sp}$, o gato-do-mato, na maior parte das vezes, encontravam-se nas estradas de terra e na monocultura de eucalipto. O avistamento e pegadas de indivíduos da espécie Dasyprocta sp, a cotia, foi bastante comum dentro e fora da A.R.I.E.. Frequente também foi o avistamento de indivíduos da espécie Eira barbara, a irara, Conepatus chinga, a jaritataca (figura 25) e Nasua nasua, o quati, que ocorreram, principalmente, junto ao curso d'água.

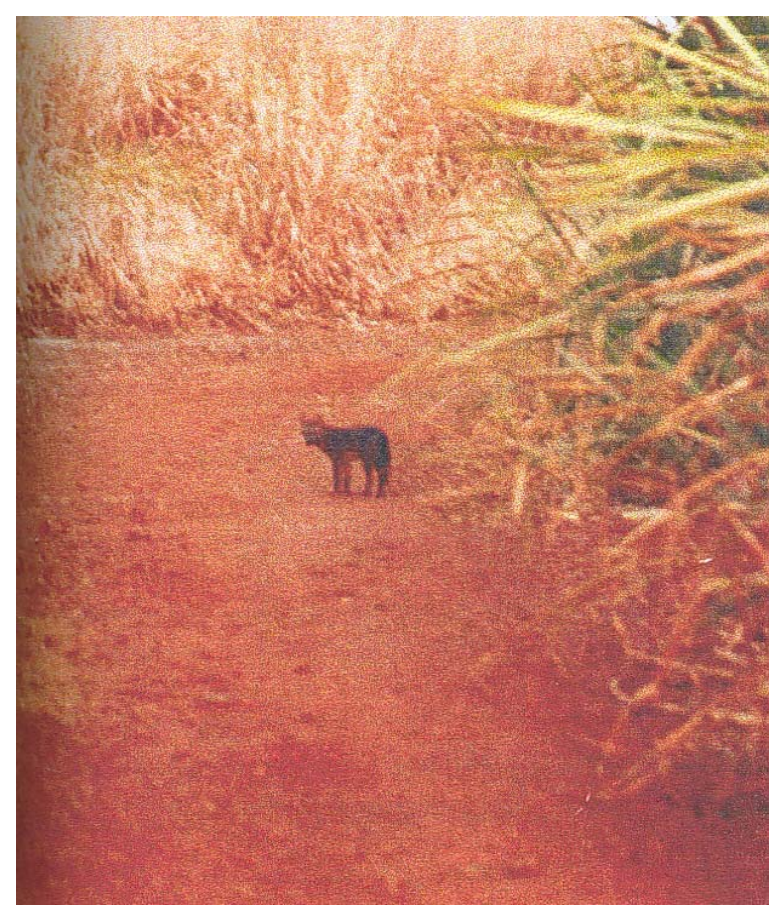

Figura 24: Indivíduo de Dusicyon thous.

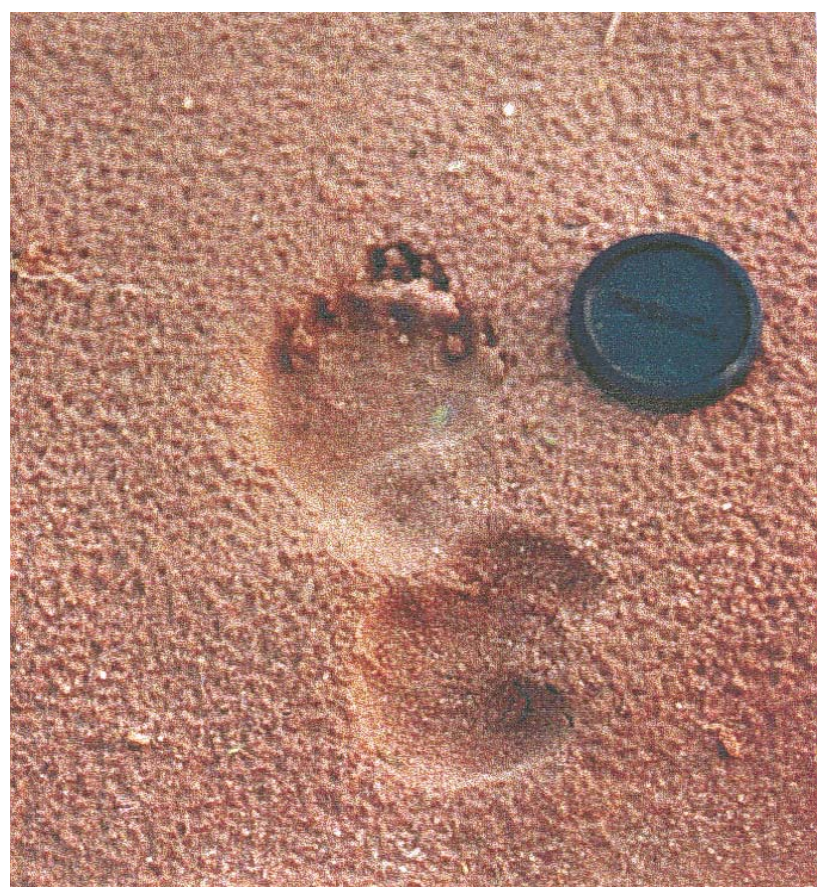

Figura 25: Pegada de Conepatus chinga.

Uma análise de agrupamento feita em função dos mamíferos de médio e grande porte e as fisionomias onde eles ocorriam, mostra que as fisionomias florestais, como eucalipto (EU), floresta ripária (FR) e floresta semidecídua (FSD), aparecem agrupadas, bem como aquelas de área mais aberta como o campo cerrado (CC) e a estrada (ES) e, um pouco mais distante, o cerrado sensu stricto (CS). O campo úmido (CU) aparece numa situação intermediária em termos de espécies coletadas, provavelmente devido a ser um ambiente 
aberto, porém, diferenciado dos outros - EU, CC, CS - pela presença de umidade e proximidade da água (figura 26).
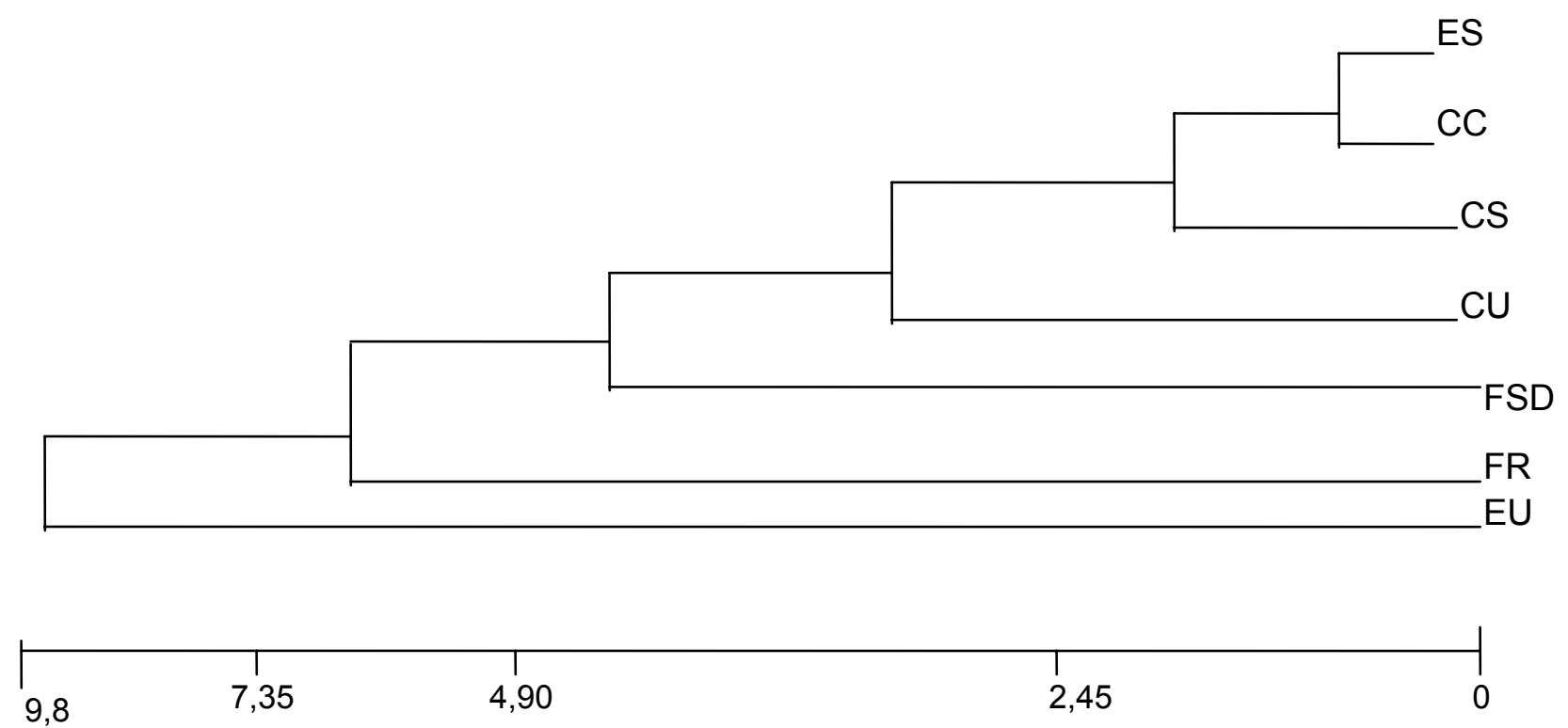

Figura 26: Dendograma resultante da análise de agrupamento com o método da mínima variância e o coeficiente da distância euclidiana, comparando as fisionomias onde foram amostrados os mamíferos de médio e grande portes. (ES: estrada, FR: floresta ripária, CU: campo úmido, EU: eucalipto, CC: campo cerrado,CS: cerrado sensu stricto, FSD: floresta semidecídua)

\subsection{Pequenos Mamíferos:}

Ao longo de 12 meses de amostragem sistemática, num esforço total de 4.896 trapnights e 324 estações de pitfall/ / dia, foram realizadas 121 capturas de indivíduos, pertencentes a 12 gêneros, sendo 8 roedores e 4 marsupiais. A tabela 2 mostra o registro de ocorrências em cada uma das fisionomias vegetais e a porcentagem da espécie por ambiente. 
Tabela 2: Frequência de ocorrência dos pequenos mamíferos nas diferentes fisionomias vegetais, e porcentagem (\%) das espécies por ambiente (FR= floresta ripária, $\mathrm{CU}=$ campo úmido, $\mathrm{CC}=$ campo cerrado, $\mathrm{CS}=$ cerrado sensu stricto, $\mathrm{FSD}=$ floresta semidecídua, EU= eucalipto)

\begin{tabular}{|c|c|c|c|c|c|c|c|c|}
\hline & ordem & total & FR & $\mathrm{CU}$ & $\mathbf{C C}$ & CS & FSD & EU \\
\hline Oligoryzomys sp & roedor & 73 & $\begin{array}{c}34 \\
46.6 \% \\
\end{array}$ & $\begin{array}{c}12 \\
16.4 \% \\
\end{array}$ & $\begin{array}{c}6 \\
8.2 \% \\
\end{array}$ & $\begin{array}{c}10 \\
13 . \% \\
\end{array}$ & $\begin{array}{c}8 \\
10.9 \% \\
\end{array}$ & $\begin{array}{c}3 \\
4.1 \% \\
\end{array}$ \\
\hline Nectomys squamipes & roedor & 3 & $\begin{array}{c}3 \\
100 \%\end{array}$ & & & & & \\
\hline Calomys sp & roedor & 23 & $\begin{array}{c}12 \\
52.1 \% \\
\end{array}$ & $\begin{array}{c}1 \\
4.34 \% \\
\end{array}$ & $\begin{array}{c}3 \\
13.0 \% \\
\end{array}$ & $\begin{array}{c}5 \\
21.7 \% \\
\end{array}$ & $\begin{array}{c}2 \\
8.7 \% \\
\end{array}$ & \\
\hline Akodon sp & roedor & 5 & $\begin{array}{c}3 \\
60 \% \\
\end{array}$ & $\begin{array}{c}1 \\
20 \% \\
\end{array}$ & & & $\begin{array}{c}1 \\
20 \% \\
\end{array}$ & \\
\hline Oryzomys sp & roedor & 1 & & & & $\begin{array}{c}1 \\
100 \% \\
\end{array}$ & & \\
\hline Bolomys lasiurus & roedor & 1 & & $\begin{array}{c}1 \\
100 \% \\
\end{array}$ & & & & \\
\hline $\begin{array}{c}\text { Pseudoryzomys } \\
\text { simplex }\end{array}$ & roedor & 1 & & $\begin{array}{c}1 \\
100 \% \\
\end{array}$ & & & & \\
\hline Oxymycterus sp & roedor & 1 & & $\begin{array}{c}1 \\
100 \% \\
\end{array}$ & & & & \\
\hline Didelphis albiventris & marsupial & 7 & $\begin{array}{c}1 \\
14.3 \% \\
\end{array}$ & & $\begin{array}{c}3 \\
42.8 \% \\
\end{array}$ & & & $\begin{array}{c}3 \\
42.8 \% \\
\end{array}$ \\
\hline Marmosa sp & marsupial & 2 & $\begin{array}{c}1 \\
50 \% \\
\end{array}$ & & & $\begin{array}{c}1 \\
50 \% \\
\end{array}$ & & \\
\hline $\begin{array}{l}\text { Gracilinanus } \\
\text { microtarsus }\end{array}$ & marsupial & 9 & & & & $\begin{array}{c}9 \\
100 \%\end{array}$ & & \\
\hline Micoureus cinereus & marsupial & 1 & $\begin{array}{c}1 \\
100 \% \\
\end{array}$ & & & & & \\
\hline Philander opossum & marsupial & 1 & $\begin{array}{c}1 \\
100 \% \\
\end{array}$ & & & & & \\
\hline
\end{tabular}

No caso dos roedores, o gênero Oligoryzomys foi o mais frequente e ocorreu em todas as fisionomias amostradas, seguido do gênero Calomys, que não teve uma frequência de ocorrência tão alta quanto do Oligoryzomys, mas que ocorreu em praticamente todas as fisionomias amostradas, exceto na monocultura de eucalipto (EU). Roedores do gênero Akodon e da espécie Nectomys squamipes aparecem a seguir, sendo este último restrito às fisionomias ligadas ao curso d'água (floresta ripária - FR). Os demais roedores, como Oryzomys sp, Bolomys lasiurus, Pseudoryzomys simplex, Oxymycterus sp foram bastante raros, tendo sua ocorrência limitada a apenas um indivíduo. A espécie Gracilinanus microtarsus (figura 27) foi a espécie de marsupial mais frequente, seguida de perto pela espécie Didelphis albiventris (figura 28). Os demais marsupiais, como Micoureus cinereus, Philander opossum e Marmosa sp, foram bastante raros, tendo sua ocorrência limitada a apenas um indivíduo. 


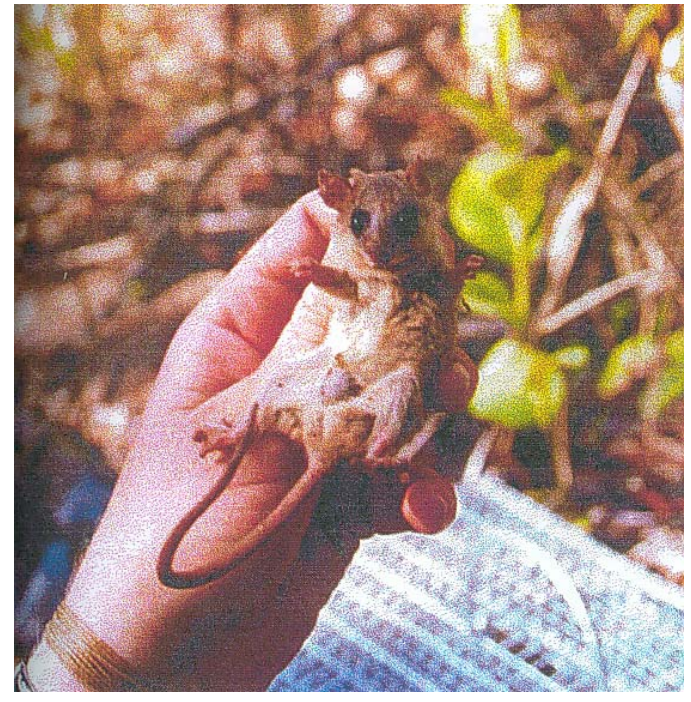

Figura 27: Indivíduo de Gracilinanus microtarsus.

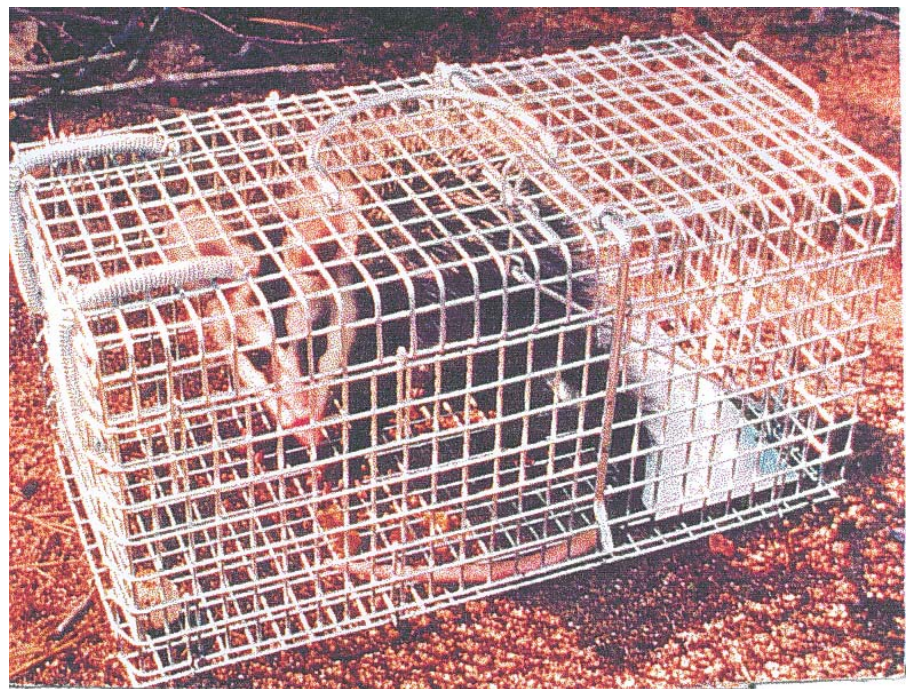

Figura 28: Indivíduo de Didelphis albiventris.

Foram registradas pouquíssimas recapturas de animais marcados com o pique na orelha: um exemplar de Oligoryzomys sp, um exemplar de Calomys sp, e dois exemplares de Gracilinanus microtarsus.

O esforço de captura referente às armadilhas de gaiola foi de 4.896 trapnights, onde foram capturados 17 animais, o que revela um sucesso de captura igual a 0,35\% .

Já com os pitfalls, o esforço de captura foi de 324 estações de pitfall/dia, onde 109 indivíduos foram capturados, conforme mostra a figura 29.

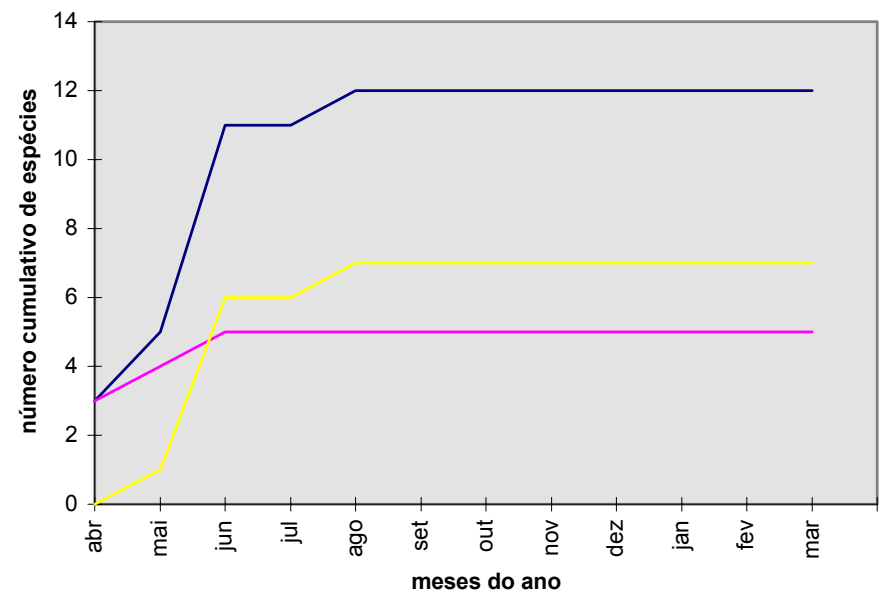

curva dos dois métodos combinados curva das armadilhas de gaiola curva dos pitfalls

Figura 29: Curvas de suficiência amostral comparando os métodos utilizados para captura dos pequenos mamíferos. 
Por meio da análise de agrupamento feita em função das epécies de pequenos mamíferos e as fisionomias onde eles ocorriam, verifica-se que o campo úmido (CU) e sta ripária (FR) ficaram agrupadas. O campo cerrado (CC) e a monocultura de eucalipto (EU) aproximaram-se, da mesma forma que a floresta semidecídua (FSD) e o cerrado sensu stricto (CS) (figura 30).

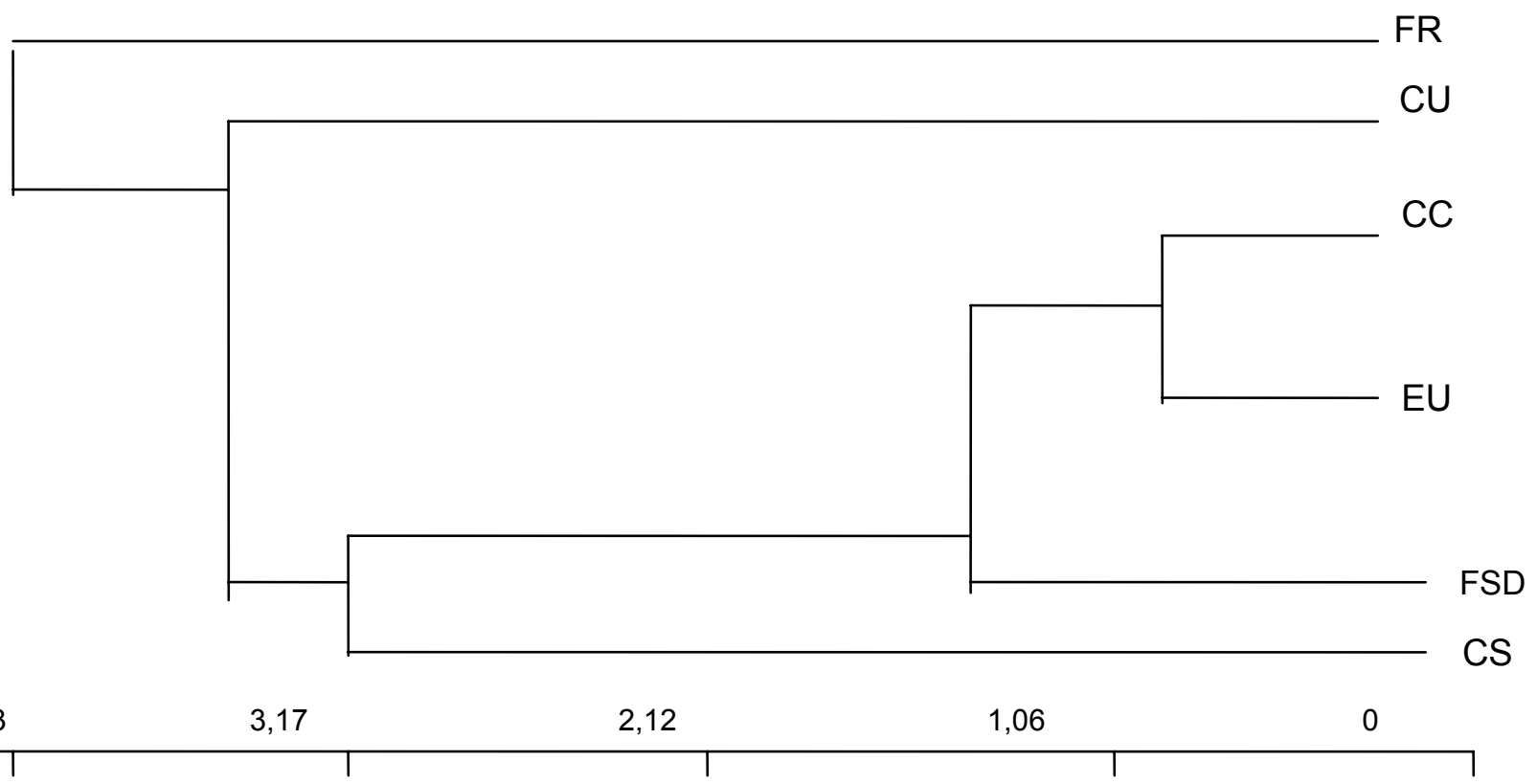

Figura 30: Dendrograma resultante da análise de agrupamento com o método da mínima variância e coeficiente da distância euclidiana, comparando as diferentes fisionomias estudadas com relação aos pequenos mamíferos amostrados. (CS: cerrado sensu stricto, FR: floresta ripária, CC: campo cerrado, CU: campo úmido, FSD: floresta semidecídua, EU: eucalipto).

A distribuição dos pequenos mamíferos capturados nos diversos habitats amostrados, indicando quais seriam os habitats preferenciais de cada espécie, está representado na figura 31. 


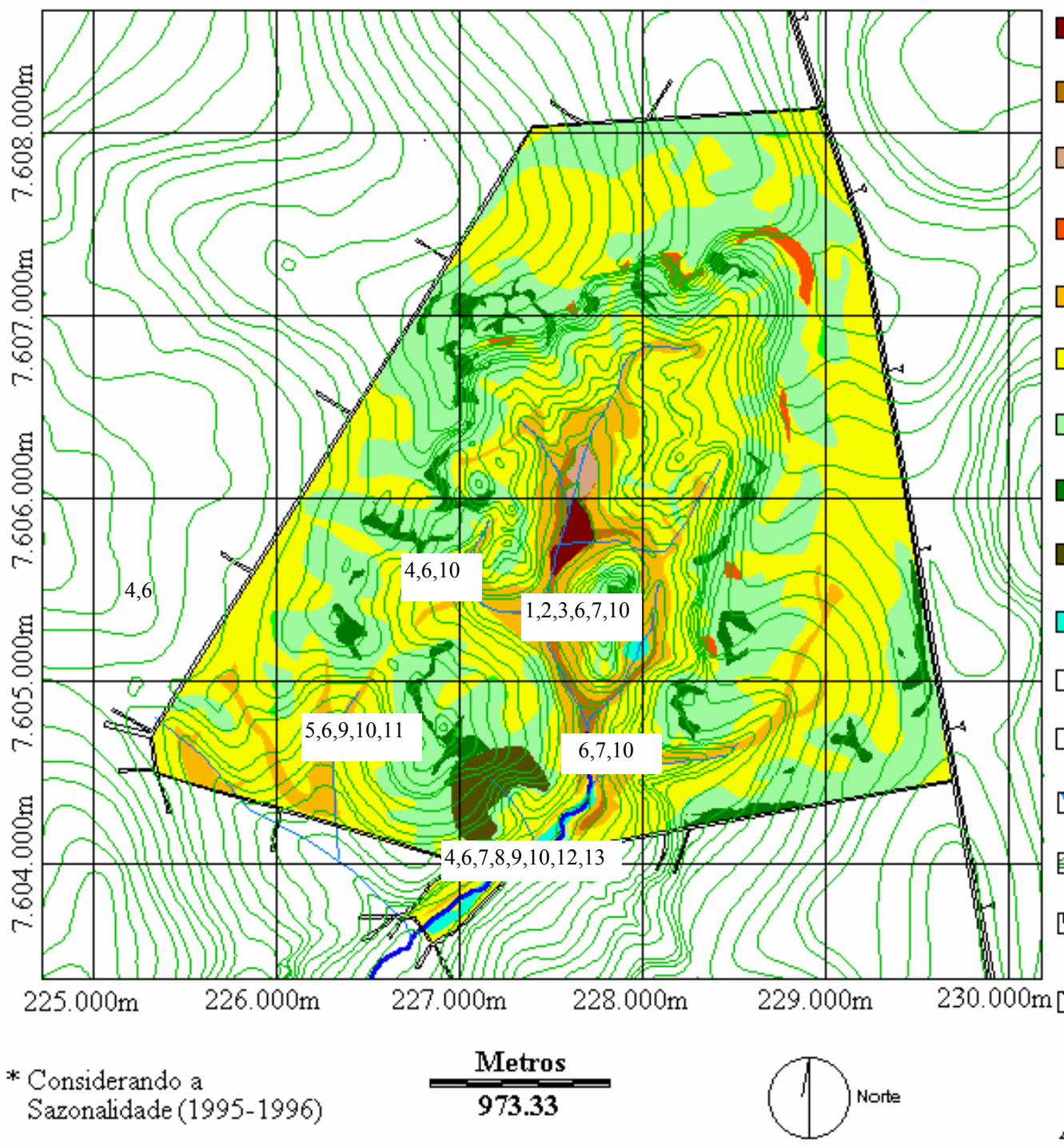

Campo Úmido com predominância de $A s p$

$\square$ Campo Limpo com predominância de $\mathrm{Mm}$

$\checkmark$ Campo com predominância de $\mathrm{Pa}$

$\square$ Campo Sujo de Encosta

$\square$ Campo Cerrado

$\square$ Cerrado stricto sensu

$\square$ Cerrado com estrato herbáceo ralo

$\square$ Cerradão

$\square$ Floresta Estacional Semidecidua

$\square$ Mata Ciliar

$\square$ Entorno

Córrego Paulicéia

Rede de Drenagem

Topografia

표며 Rodovia nhanguera

Estrada não-pavimentada

Asp $=$ Andropogon sp

$M m=$ Melinis minutiflora

$P a=P$ teridium aquilinum

Figura 31: Localização dos habitats preferenciais dos pequenos mamíferos da A.R.I.E. Cerrado Pé-deGigante (1: Bolomys lasiurus, 2: Pseudorizomys simplex, 3: Oxymycterus sp, 4: Didelphis albiventris, 5: Gracilinanus microtarsus, 6: Oligoryzomys sp, 7: Akodon sp, 8: Nectomys squamipes, 9: Marmosa sp, 10: Calomys sp, 11: Oryzomys sp, 12: Micoureus cinereus, 13: Philander opossum).

Os índices de diversidade de Shannon-Wienner calculados para os pequenos mamíferos amostrados em cada uma das fisionomias encontram-se na tabela 3 . 
Tabela 3: Índice de Shannon-Wienner, dos pequenos mamíferos, para cada fisionomia amostrada ( $F R=$ floresta ripária, $\mathrm{CU}=$ campo úmido, $\mathrm{CC}=$ campo cerrado, $\mathrm{CS}=$ cerrado sensu stricto, $\mathrm{FSD}=$ floresta semidecídua, $\mathrm{EU}=$ eucalipto).

\begin{tabular}{|l|l|l|l|l|l|l|}
\hline $\begin{array}{l}\mathrm{H}^{\prime} \\
\text { bits / indivíduo }\end{array}$ & FR & CU & CC & CS & FSD & EU \\
\hline & 1.78 & 1.56 & 1.50 & 1.88 & 1.09 & 1.00 \\
\hline
\end{tabular}

Os roedores mostraram-se mais abundantes que os marsupiais em todas as fisionomias amostradas, sendo os únicos a ocorrerem nas fisionomias campo úmido (CU), floresta semidecídua (FSD). Os marsupiais mostram-se mais abundantes somente na fisionomia cerrado sensu stricto (CS) (figura 32).

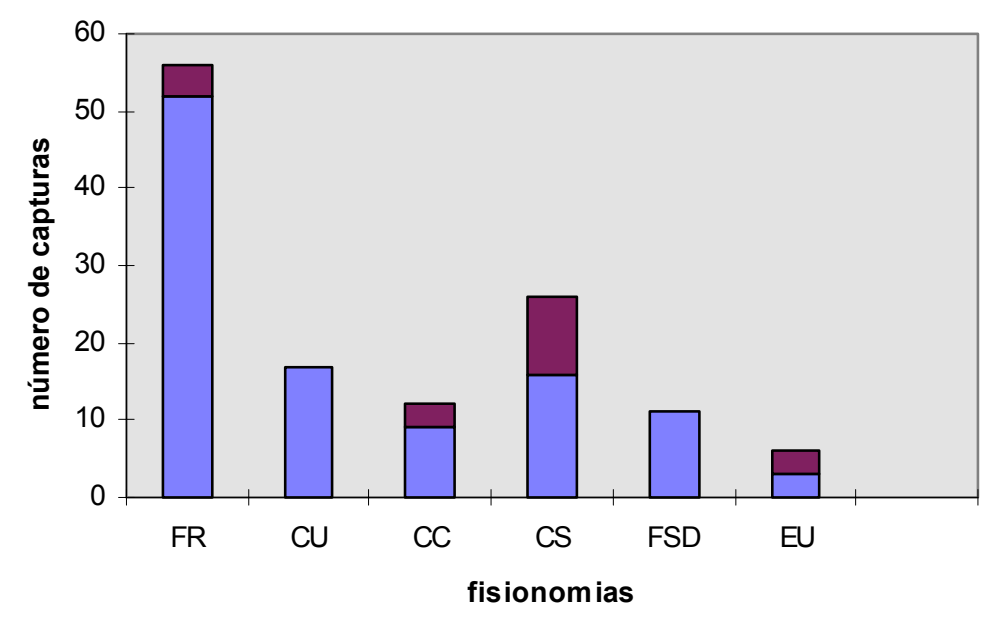

Figura 32: Frequência de ocorrência comparativa entre roedores e marsupiais nas diferentes fitofisionomias na A.R.I.E.Cerrado Pé-de-Gigante (CS: cerrado sensu stricto, FR: floresta ripária, CC: campo cerrado, CU: campo úmido, FSD: floresta semidecídua, EU: eucalipto.

A figura 33 demonstra o sucesso de captura dos pequenos mamíferos ao longo dos 12 meses de coleta, tanto nas gaiolas quanto nos pitfalls. Nota-se um sucesso maior nos meses correspondentes às estações secas, com um pico no mês de junho. O número de capturas de marsupiais mostrou-se invariavelmente menor que de roedores, sendo nulo nos meses de setembro, novembro, dezembro e fevereiro. 


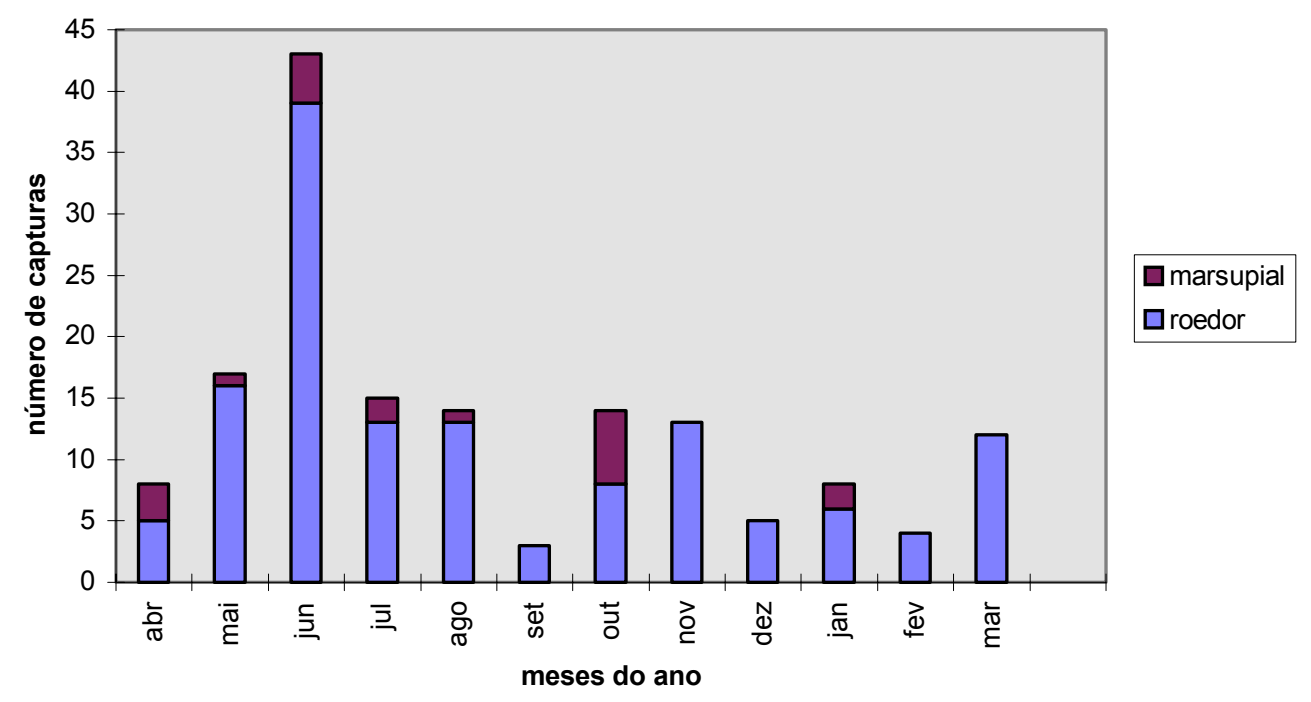

FIGURA 33: Sucesso de captura de roedores e marsupiais ao longo do período de coletas, na A.R.I.E. Cerrado Pé-de-Giagante.

A figura 34 demonstra a temperatura $\left({ }^{\circ} \mathrm{C}\right)$ e a precipitação pluviométrica $(\mathrm{mm})$ ao longo do período de coleta e a figura 35 mostra a relação entre o número de capturas ao longo do período de coletas (abr 97-mar 98), com a precipitação pluviométrica $(\mathrm{mm})$ neste mesmo período. Nota-se que o período de maior precipitação é o mesmo de menor sucesso de captura.

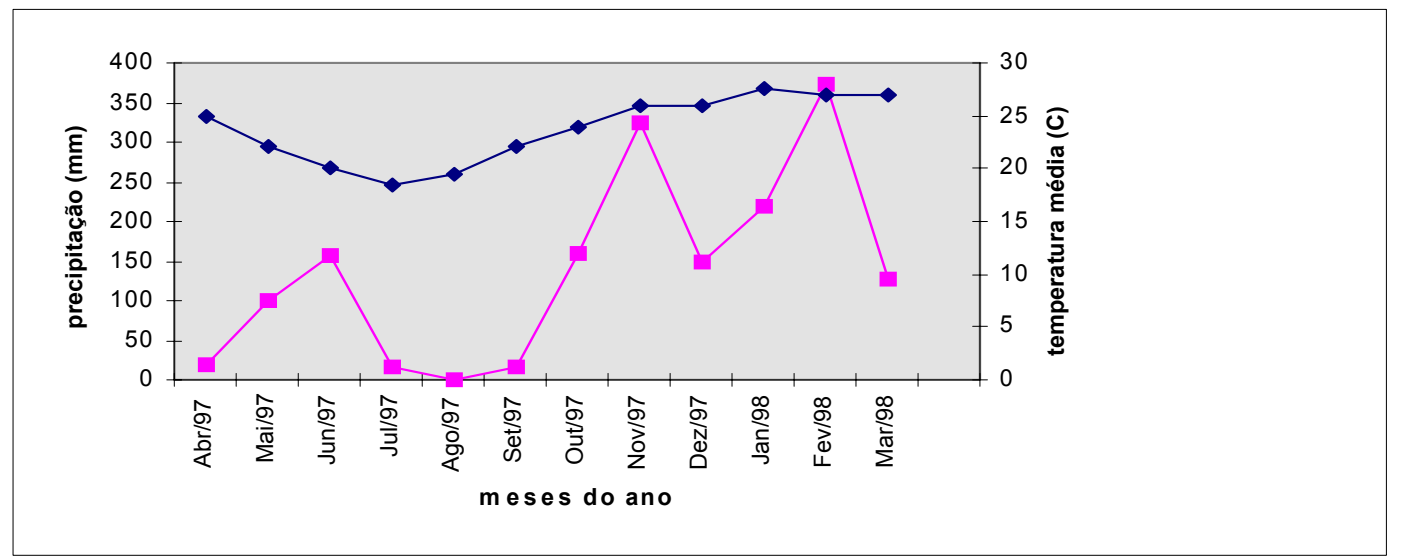

- temperatura $\left({ }^{\circ} \mathrm{C}\right)$

precipitação $(\mathrm{mm})$

Figura 34: Precipitação $(\mathrm{mm})$ e temperatura média $\left({ }^{\circ} \mathrm{C}\right)$ ao longo do período de coletas no município de Santa Rita do Passa-Quatro (FONTE: CELPAV). 


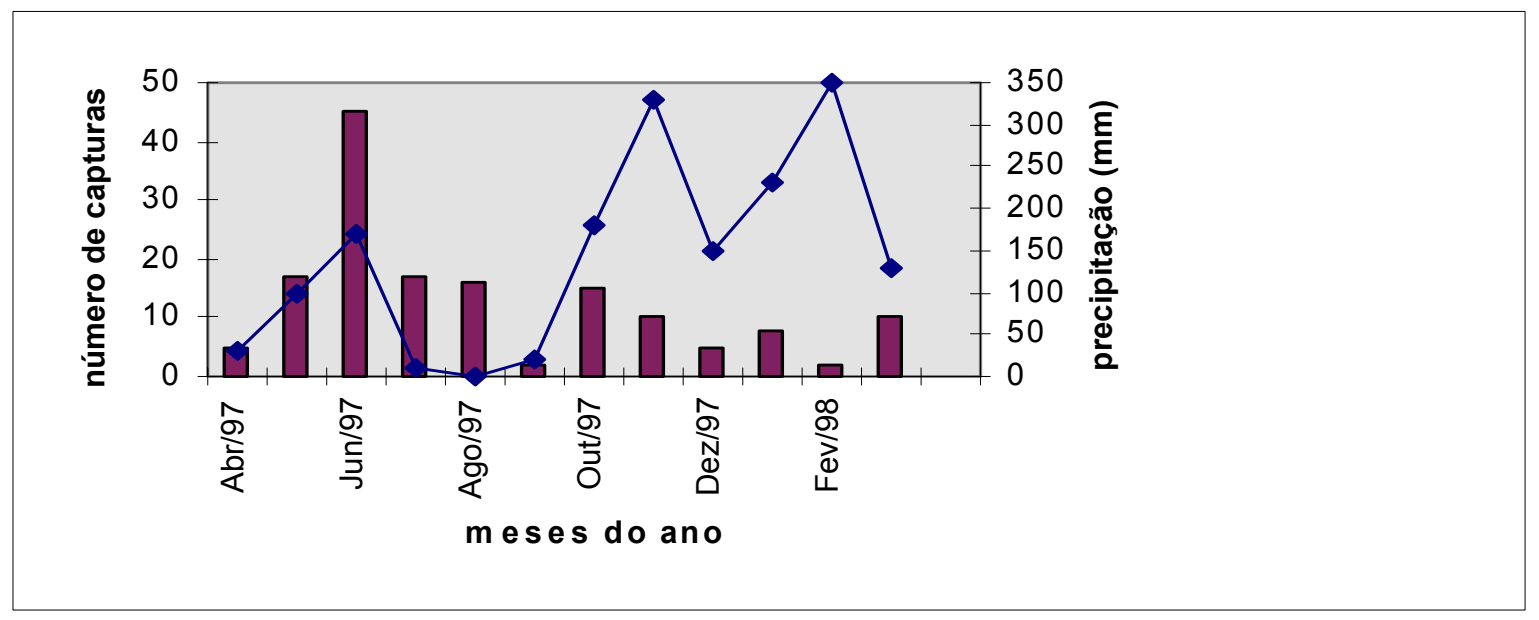

_ precipitação pluviométrica $(\mathrm{mm})$

número de capturas

Figura 35: Relação entre o número de capturas e a precipitação pluviométrica $(\mathrm{mm})$ ao longo do período de coletas.

A figura 36 mostra as épocas de frutificação/floração e o sucesso de captura ao longo do período de coletas. O número de espécies em floração foi mais elevado no período que vai de setembro a abril, atingindo seu valor máximo em fevereiro e mínimo em agosto. A produção de frutos também se deu para um maior número de espécies no período entre setembro e maio logo após a floração, sendo este um período chuvoso (Batalha, 1998).

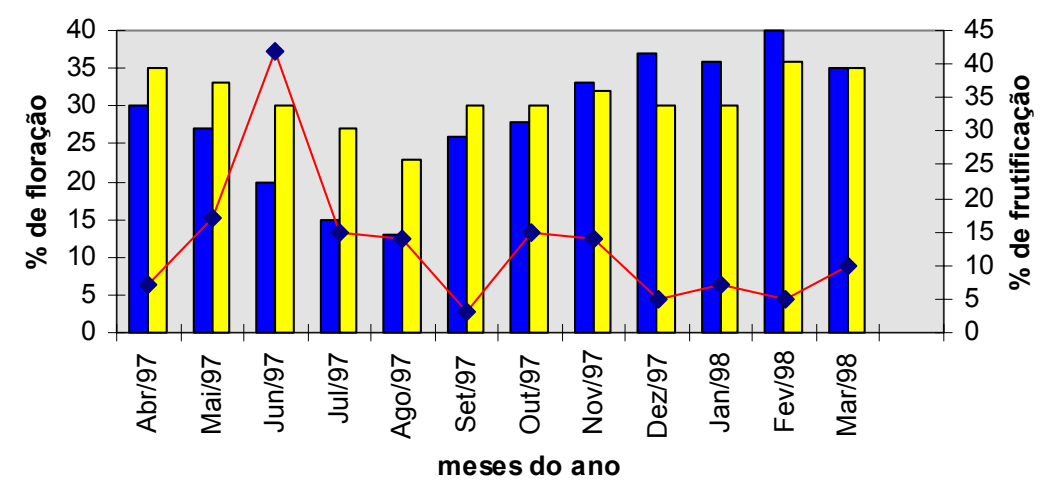

\% de espécies de cerrado "sensu lato" em floração ao longo do período de coletas na Reserva. \% de espécies de cerrado "sensu lato" em frutificação ao longo do período de coletas na Reserva.

Número de espécies de pequenos mamíferos capturadas no período.

Figura 36: Período de frutificação e floração e sua relação com as capturas. Dados fenológicos obtidos em Batalha,1998. 
As medidas morfométricas dos pequenos mamíferos (figura 37) encontramse nas tabelas 4 E 5. A maior espécie de roedor encontrada foi o Nectomys squamipes, e o menor o Oligoryzomys sp, enquanto que o maior marsupial foi o Didelphis albiventris, e o menor a Marmosa sp.

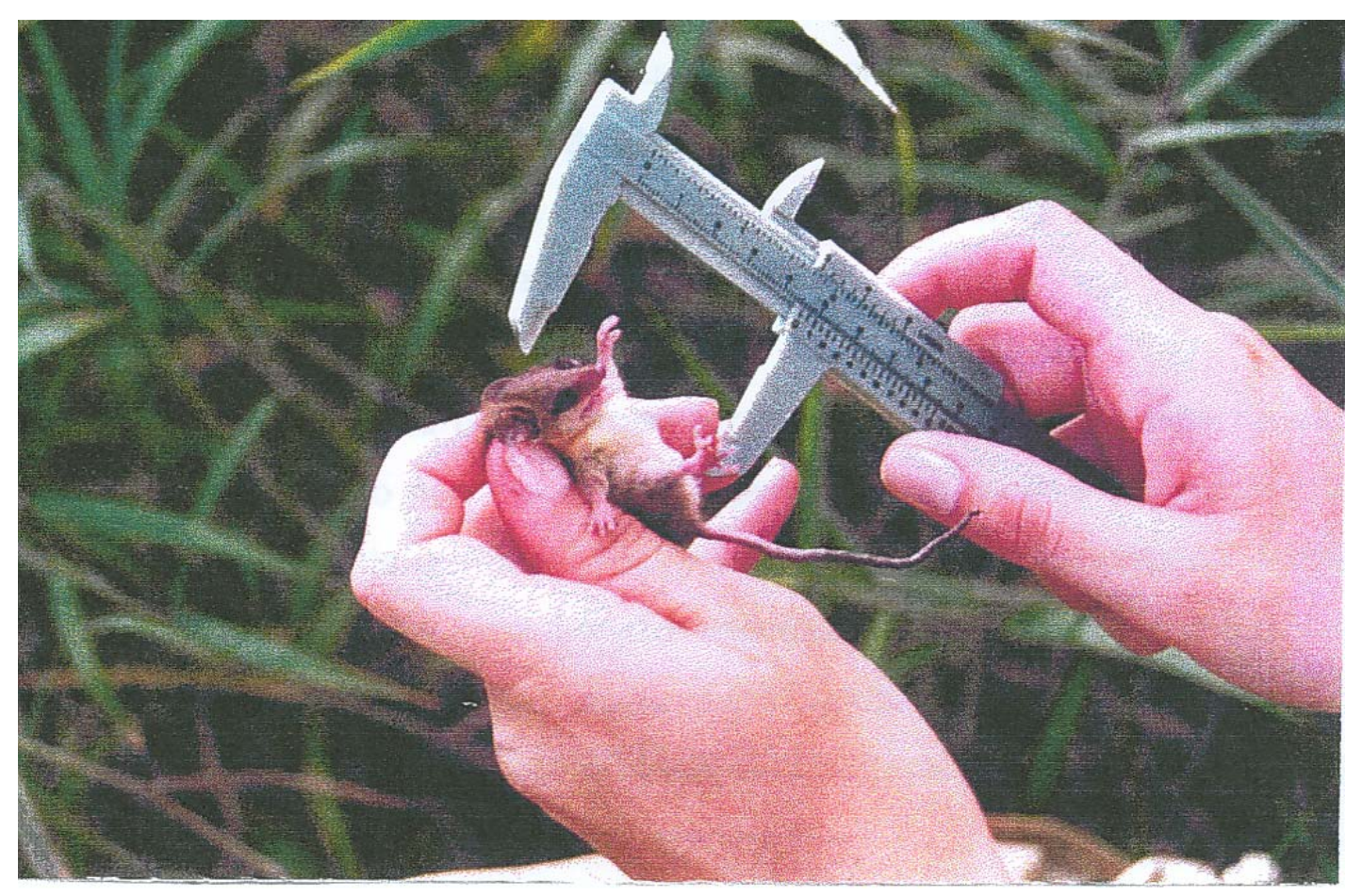

Figura 37: Medidas tomadas dos pequenos maíferos em campo.

Tabela 4: Dados morfométricos dos roedores capturados na A.R.I.E. Cerrado Pé-de-Gigante (média= $x$ e desvio padrão= $\delta$ ) .

\begin{tabular}{|l|l|l|l|l|l|l|l|l|l|l|l|}
\hline & \multicolumn{3}{|l|}{ Oligoryzomys } & \multicolumn{2}{l|}{ Calomys } & \multicolumn{2}{l|}{ Akodon } & \multicolumn{2}{l|}{ Bolomys } & \multicolumn{2}{l|}{ Nectomys } \\
\hline em centímetros & $\mathbf{x}$ & $\delta$ & $\mathbf{x}$ & $\delta$ & $\mathbf{x}$ & $\delta$ & $\mathbf{x}$ & $\delta$ & $\mathbf{x}$ & $\delta$ \\
\hline corpo & 6.17 & 0.85 & 6.92 & 1.13 & 7.5 & 1.32 & 14.5 & ${ }^{*}$ & 16.0 & ${ }^{*}$ \\
\hline cauda & 8.36 & 1.84 & 7.04 & 1.82 & 6.2 & 3.86 & 15.0 & ${ }^{*}$ & 18.0 & ${ }^{*}$ \\
\hline pata traseira & 1.89 & 0.26 & 1.831 & 0.236 & 1.86 & 0.23 & 3.5 & ${ }^{*}$ & 4.5 & ${ }^{*}$ \\
\hline
\end{tabular}

* Somente um exemplar capturado. Não há $\delta$.

Tabela 5: Dados morfométricos dos marsupiais capturados na A.R.I.E. Cerrado Pé-de-Giagnte (média= $x$ e desvio padrão= $\delta$ ).

\begin{tabular}{|c|c|c|c|c|c|c|}
\hline & \multicolumn{2}{|c|}{ Marmosa } & \multicolumn{2}{c|}{ Gracilinanus } & \multicolumn{2}{c|}{ Didelphis albiventris } \\
\hline em centímetros & $\mathbf{x}$ & $\delta$ & $\mathbf{x}$ & $\delta$ & $\mathbf{x}$ & $\delta$ \\
\hline corpo & 5.0 & 1.0 & 5.5 & 1.30 & 28.0 & 1.45 \\
\hline cauda & 3.5 & 2.95 & 6.0 & 3.75 & 23.0 & 3.90 \\
\hline pata traseira & 0.8 & 0.8 & 1.0 & 1.2 & 3.0 & 0.8 \\
\hline \multicolumn{2}{|r|}{} & & & & & \\
\hline
\end{tabular}




\subsection{Caracterização dos Habitats:}

As fisionomias identificadas, definidas e caracterizadas por Batalha (1997) na A.R.I.E. Cerrado Pé-de-Gigante, constantes do mapeamanto realizado por Mesquita Jr. (1998) (figura 10) estão descritas a seguir. Incorporou-se à descrição informações coletadas para aquelas fisionomias amostradas neste estudo e caracterizadas em maior detalhe. Segue-se à descrição das fisionomias amostradas um diagrama de perfil, onde se pode observar o porte da vegetação, sua estratificação e riqueza específica.

Campo úmido com predominância de Andropogon spp = Ocorre na planície de inundação do córrego Paulicéia e, durante o período de maior pluviosidade, a área permanece alagada, pelo período de aproximadamente um mês. Possui um estrato apenas, contínuo, formado por garmíneas do gênero Andropogon, cuja porção vegetativa atinge de 1 a 1,5m de altura, podendo atingir até $2 \mathrm{~m}$ quando lançam seu pedúnculos florais. Predominam as hemicriptófitas, também havendo caméfitas. Sua topografia é plana, a cobertura vegetal é abundante e o solo é mais compactado que nas demais fisionomias (tabela 6).

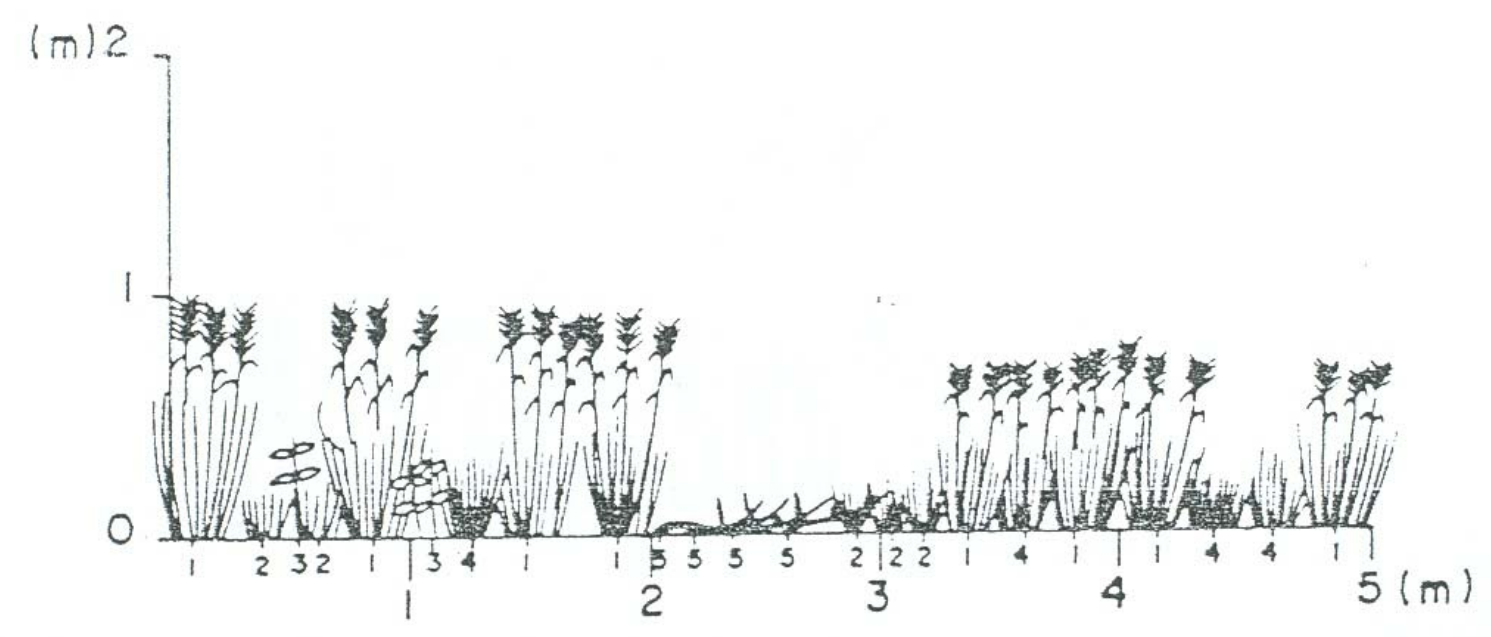

Figura 38: Diagrama de perfil do campo úmido, segundo Batalha, 1997. (1) Andropogon bicornis; 2) Bulbostylis hirtella; 3) Tobouchina gracilis; 4) Andropogon leucostachys; 5) Polygonum acre). 
Floresta Estacional Semidecídua $=$ Podem ser distintos quatro estratos: $\mathrm{O}$ estrato arbóreo é superior a $10 \mathrm{~m}$ de altura, formando um dossel contínuo. Algumas árvores emergentes atingem até $20 \mathrm{~m}$ de altura. O componente herbáceo é pouco desenvolvido, formado por espécies tipicamente umbrófilas e, principalmente, por indivíduos jovens dos estratos superiores. Várias espécies do componente arbóreo perdem as folhas na estação seca (maio a setembro). Dentre as formas de vida encontradas (segundo Muller-Dombois \& Ellenberg 1974) há um predomínio marcante de fanerófitas, além de muitas lianas e epífitas e poucas hemicriptófitas. O solo é argiloso, coberto por uma camada contínua de serrapilheira, com baixa compactação; a topografia local é levemente inclinada (tabela 6).
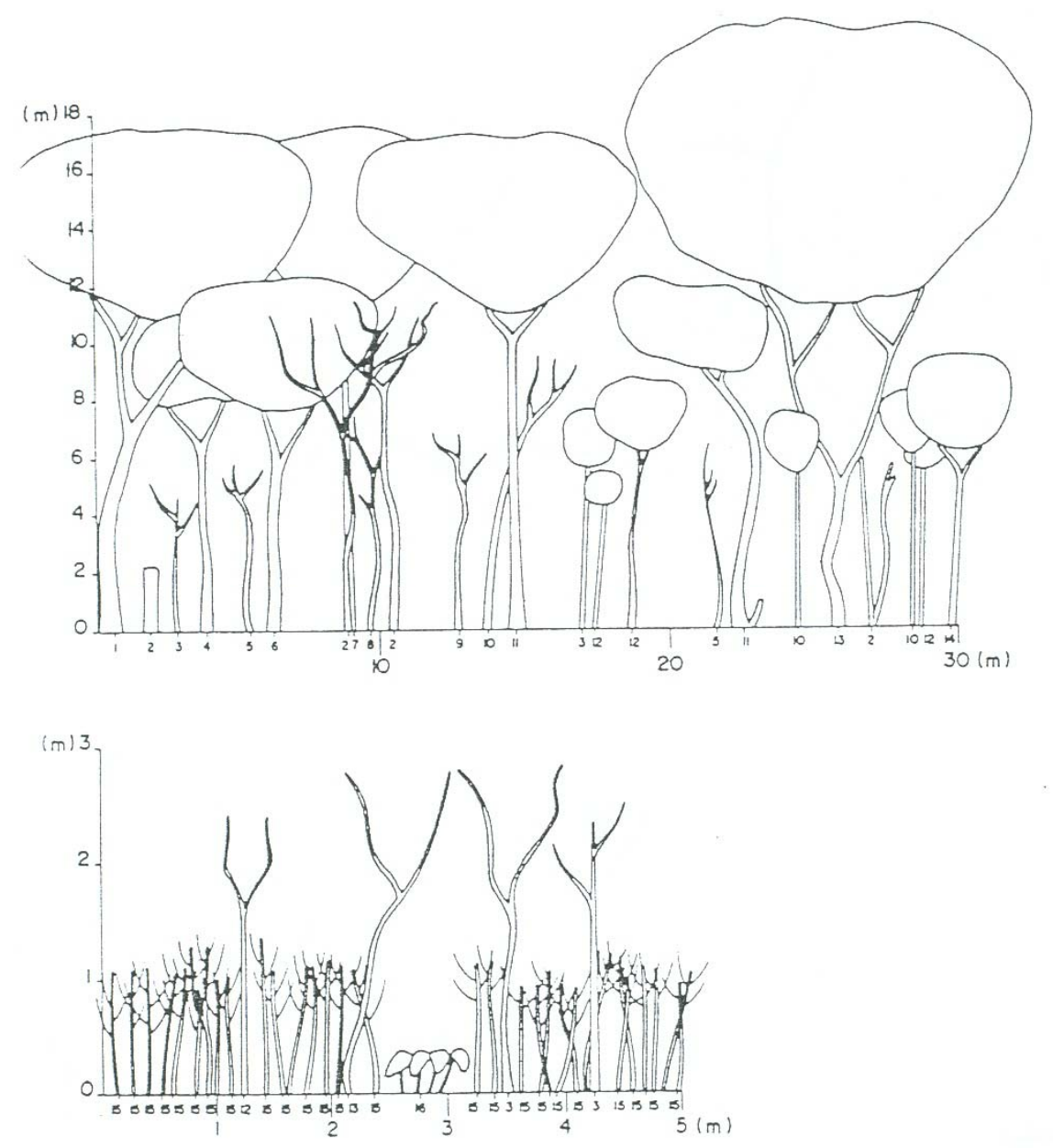

Figura 39: Diagrama de perfil da floresta estacional semi-decídual, segundo Batalha, 1997. (1) Machaerium villosum; 2) Morta; 3) Esenbeckia febrifuga; 4) Copaifera langsdorf; 5) Ocotea corymbosa; 6) Tabebuia serratifolia; 7) Cordia sellowiana; 8) Lacistema floribundum; 9) Matayba elaeagnoides; 10) Croton floribundus; 11) Platypodium elegans; 12) Cupania vernalis; 13) Anadenathera macrocarpa; 14) Dalbergia frutescens; 15) Actinostemon communis; 16) Calathea zebrina). 
Floresta ripária = Ocupa uma faixa estreita e restrita à proximidade do curso d'água do córrego Paulicéia, onde ocorrem espécies adaptadas ao solo permanentemente umedecido. Ocorrem árvores de até $12 \mathrm{~m}$ de altura no estrato superior; o sub-bosque apresenta arvoretas e palmeiras de 2 a $5 \mathrm{~m}$ de altura e o estrato herbáceo é formado principalmente por indivíduos jovens dos estratos superiores. As formas de vida predominantes são também fanerófitas, com frequentes lianas e poucas hemicriptófitas. Sua topografia, a exemplo da floresta semidecidual, é levemente inclinada, pois também se encontra no pequeno vale do córrego Paulicéia. Seu solo é argiloso, com cobertura vegetal morta e compactação baixa (tabela 6).

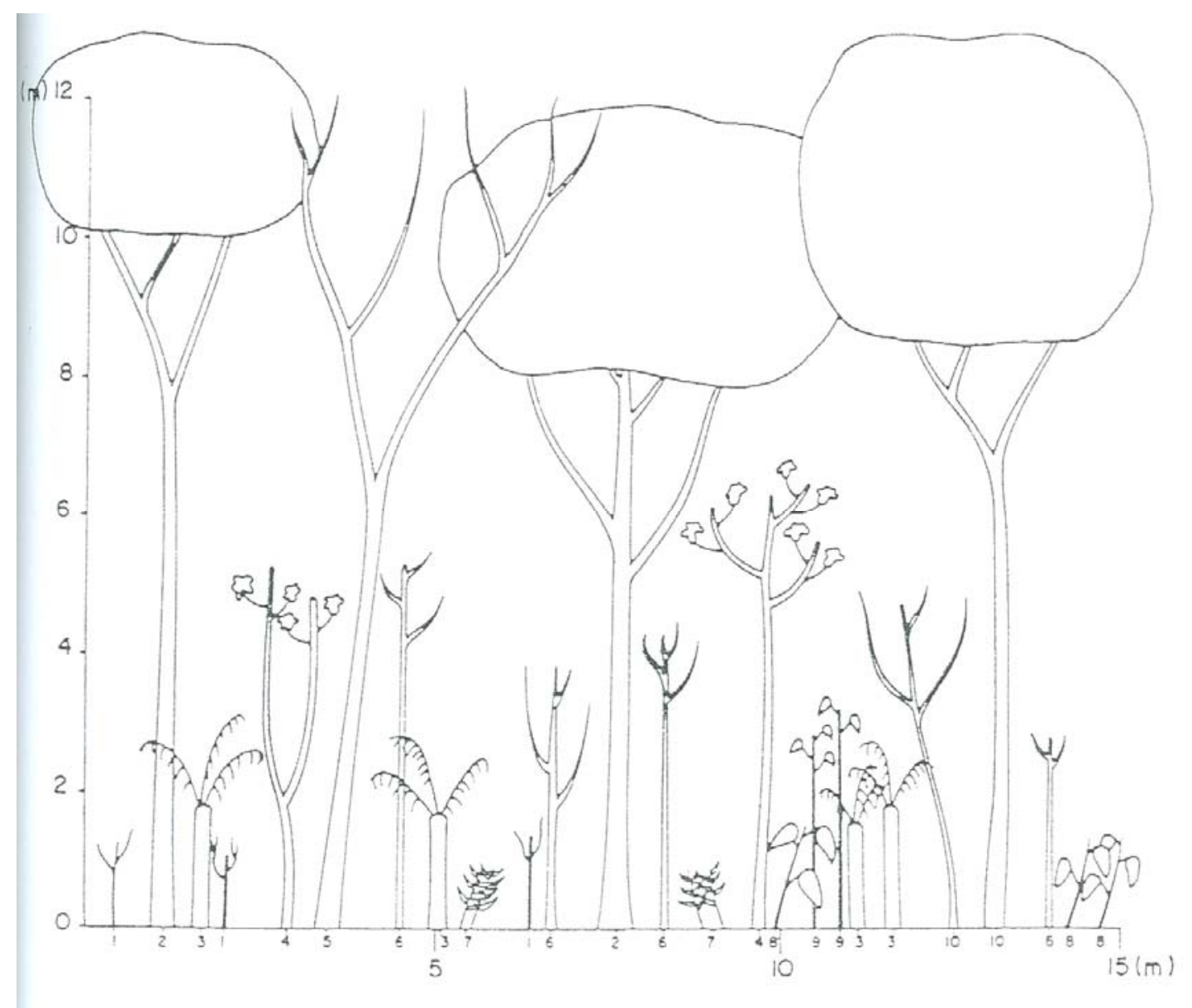

Figura 40: Diagrama de perfil da floresta ripária, segundo Batalha, 1997. (1) Siparuna apiosyce; 2) Inga uruguensis; 3) Cyathea delgadii; 4) Cecropia pachystachya; 5) morta; 6) Hyeronima alchorneoides; 7) Thelypteris salzamanii; 8) Heliconia hirsuta; 9) Croton urucurana; 10) Tapira guinansis). 
Cerrado sensu stricto $=$ Distingue-se três estratos: o herbáceo-sub-arbustivo, que alcança até $1,5 \mathrm{~m}$ de altura e não é contínuo; o arbustivo, com arvoretas de até $4 \mathrm{~m}$ altura; e o arbóreo, com árvores superiores a $4 \mathrm{~m}$ de altura. Há algumas árvores emergentes que podem atingir até 10m.A maior parte das espécies são decíduas e perdem suas folhas na estação seca. As formas de vida encontradas são hemicriptófitas, caméfitas e fanerófitas. Assim como o campo cerrado sua topografia é plana e seu solo arenoso, com cobertura vegetal viva e compactação baixa (tabela 6 ).
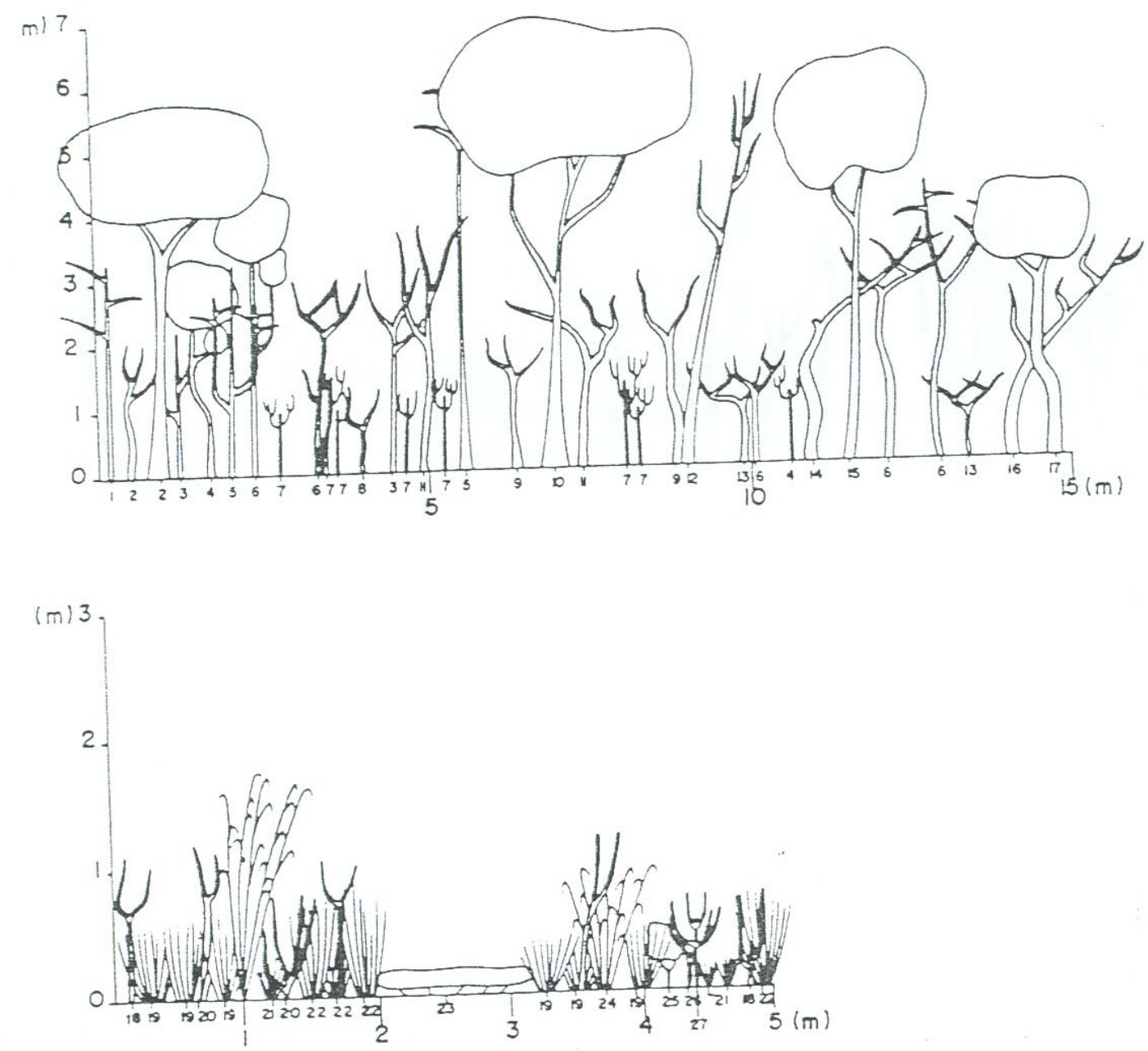

Figura 41: Diagrama de perfil do cerrado sensu stricto, segundo Batalha, 1997 . (1) Virola sebifera; 2) Copaifera langsdorf; 3) Myrcia lasiantha; 4) Dyptichandra aurantiaca; 5) Xylopia aromatica; 6) Myrcia lingua; 7) Chamaechrista debilis; 8) Piptocapha rotundifolia; 9) Ouratea spectabilis; 10) Dalbergia miscolobium; 11) Stryphnodendron polyphyllum; 12) Pouteria torta; 13) Erythroxylum suberosum; 14) Neea theifera; 15) Pteron pubescens; 16) Annona coriacea; 17) Myrcia uberavensis; 18) Connarus suberosus; 19) Axonopus marginatus; 20) Miconia albicans; 21) Bulbostylis hirtella; 22) Loudetiopsis chysothrix; 23) Andira laurifolia; 24) Scleria comosa; 25) Chamaechrista desvauxii; 26) Rourea induta; 27) Memora preregrine). 
Campo cerrado $=$ Possui dois estratos bem definidos: o herbáceo-sub-arbustivo, predominante, onde se encontram arbustos de até $2 \mathrm{~m}$ de altura; e outro, arbustivo-arbóreo, com predomínio de arvoretas em torno de $4 \mathrm{~m}$ de altura; árvores de 7 a $10 \mathrm{~m}$ de altura ocorrem muito esparsamente. A maior parte das espécies perde suas folha na estação seca, porém, não ao mesmo tempo, sempre havendo recursos à fauna. Dentre as formas de vida, predominam as hemicriptófitas, havendo também caméfitas e fanerófitas. Sua topografia é plana e seu solo arenoso, com cobertura vegetal viva e compactação baixa (tabela 6).
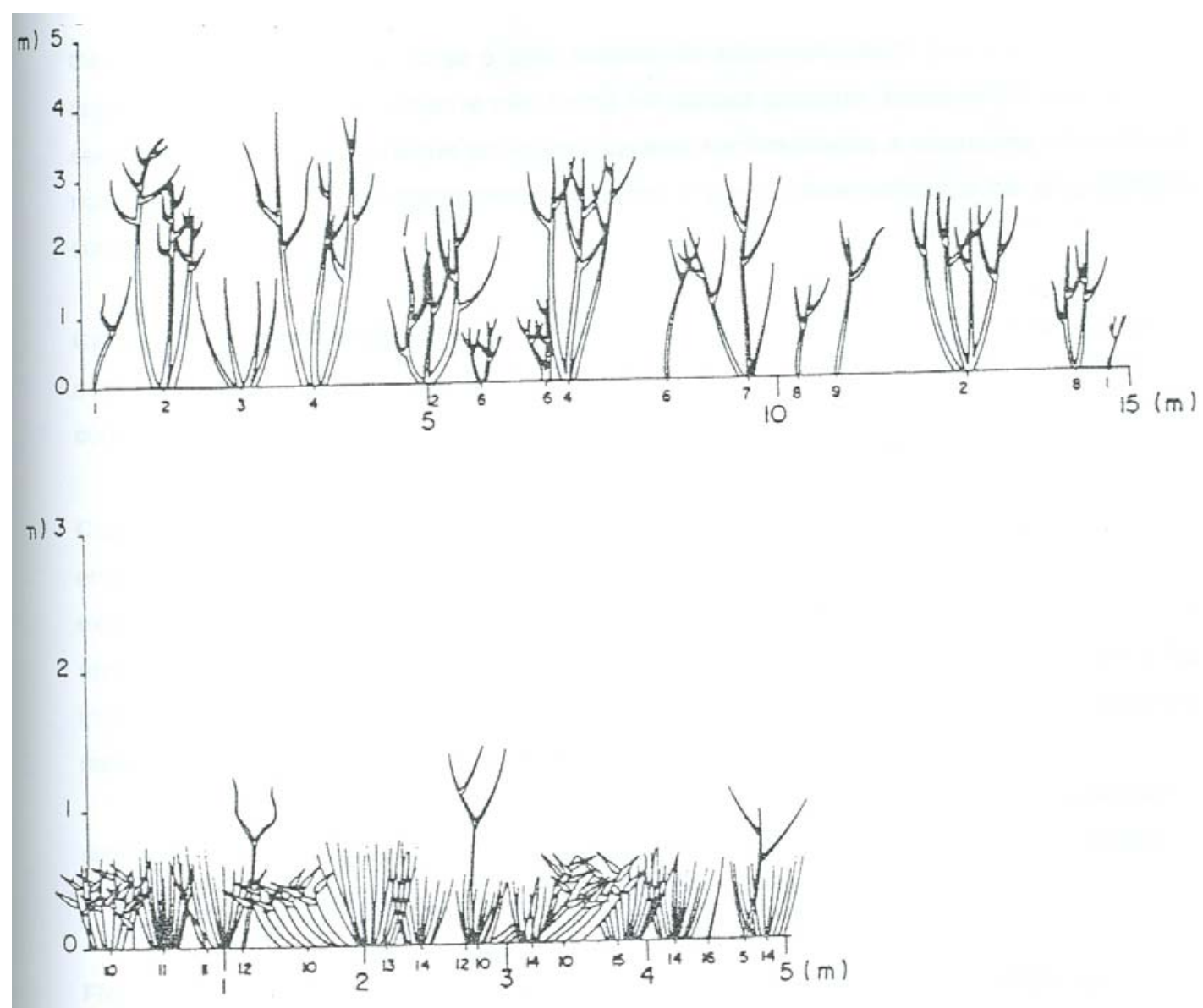

Figura 42: Diagrama de perfil do campo cerrado, segundo Batalha, 1997. ( 1) Psidium australe; 2)

Pouteria ramiflora; 3) Veronia rubriramea; 4) Bauhinia rufa; 5) Byrsonima intermedia; 6) Lippia salviifolia; 7) Kielmeyera variabilis; 8) Caryocar brasiliense; 9) Stryphnodendron adstringens; 10) Melinis minutiflora; 11) Axonopus marginatus; 12) Campomanesia pubescens; 13) Tristachya leiostachya; 14) Axonopus barbigerus; 15) Loudetiopsis chrysothrix; 16) Peixotoa tomentosa). 
Campo sujo de encosta = Há predomínio de gramíneas de no máximo 0,5 $\mathrm{m}$ de altura, com algumas arvoretas ou arbustos esparsos; em muitos locais, o solo está totalmente exposto.

Cerrado sensu stricto com estrato herbáceo ralo $=$ Predominam árvores de até $10 \mathrm{~m}$ de altura, que não chegam a formar um dossel contínuo, mas provocam um razoável sombreamento nos estratos mais baixos, causando um rareamento do estrato herbáceo ralo e uma camada contínua de serrapilheira.

Cerradão $=$ Embora não atinja o grau máximo de desenvolvimento que poderia ter nesta região do Estado de São Paulo e não forme um dossel contínuo, predominam aqui árvores com cerca de $10 \mathrm{~m}$ de altura,que provocam razoável sombreamento e microclima mais ameno nos estratos inferiores. O componente herbáceo é pouco desenvolvido e há uma camada contínua de serrapilheira.

Campo limpo com predominância de Melinis minutiflora = Ocorre nas partes um pouco mais elevadas, não sujeitas ao alagamento, contudo, ainda na planície de inundação do córrego Paulicéia. Este campo limpo é dominado pela gramínea Melinis minutiflora.

Campo com predominancia de Pteridium aquilinum $=$ Nas proximidades do campo úmido, encontra-se uma paisagem diferenciada, em decorrência da flora local ser quase exclusivamente composta de pteridófitas da espécie Pteridium aquilinum. Os indivíduos atingem de 1 a 1,5m de altura e distribuem-se em mancha única e contínua, na planície de inundação do córrego Paulicéia, porém numa área que permanece fora da lâmina d'água até mesmo durante o período de maior precipitação.

Além das fisionomais acima, existentes na A.R.I.E. Cerrado Pé-de-Gigante, segue-se a caracterização da floresta homogênea de eucaliptos, contígua a A.R.I.E., conforme se encontra no talhão amostrado.

Floresta homogênea de eucaliptos= Apresentava dois estratos, um herbáceo, constituído basicamente da gramínea Melinis minutiflora, com cerca $0,5 \mathrm{~m}$ de altura e um arbóreo, homogêneo, com cerca de 28-30m de altura, formado por indivíduos de Eucaliptus sp com cerca de 7 anos. As formas de vida encontradas são predominantemente fanerófitas (Eucaliptus) e hemicriptófitas (gramíneas). Sua topografia é plana e seu solo é arenoso, com 
cobertura vegetal morta, formando uma grande quantidade de folhedo; a compactação do solo baixa (tabela 6$)$.

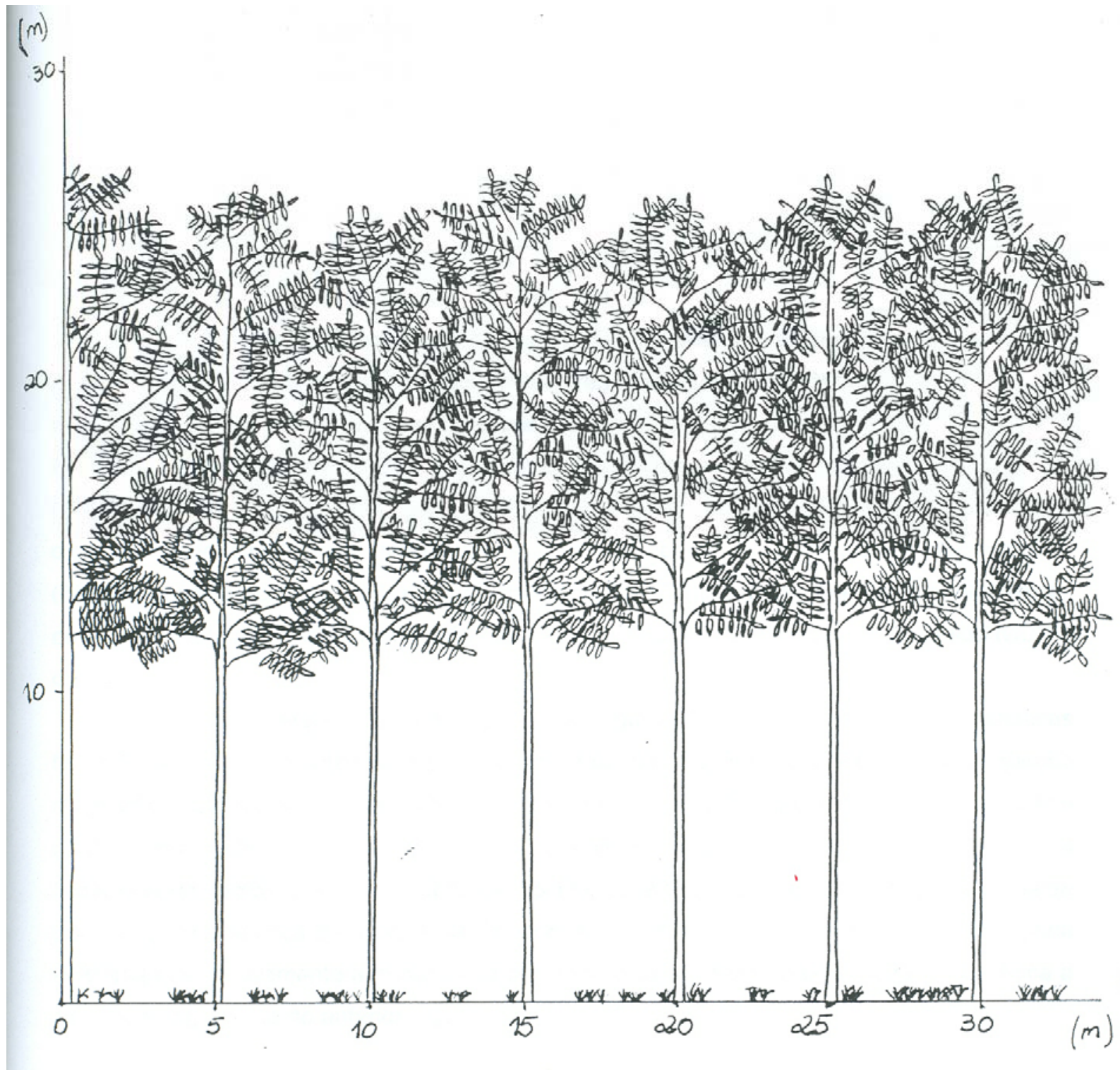

Figura 43: Diagrama de perfil da floresta homogênea de eucaliptos. Legenda: 1) Eucaliptus spp; 2) Melinis minutiflora.(Elaborado por Rugiero, P.G.C.) 
Tabela 6: Características fisiográficas dos habitats amostrados na A.R.I.E. Cerrado Pé-de-Gigante (escala arbitrária utilizada para caracterizar quantidade de folhedo e compactação do solo: 0= não há, 1= pouco, 2= médio,3= muito; quantidade de estrato herbáceo: I=0-20\%, II=20-40\%, III=40-60\%, IV=60$80 \%, V=80-100 \%$; recursos: $\mathrm{BC}=$ buracos de tatu, $C=$ cupinzeiros, $F=$ formigueiros; FR: floresta ripária, CU: campo úmido, EU: eucalipto, CC: campo cerrado, CS: cerrado sensu stricto, FSD: floresta semidecídua).

\begin{tabular}{|c|c|c|c|c|c|c|c|c|c|c|c|}
\hline \multirow[t]{2}{*}{ FISIONOMIA } & \multirow[t]{2}{*}{ TOPOGRAFIA } & \multicolumn{4}{|c|}{ SOLO } & \multicolumn{4}{|c|}{ VEGETAÇÃO } & \multirow[t]{2}{*}{$\begin{array}{c}\text { OUTROS } \\
\text { RECURSOS }\end{array}$} & \multirow{2}{*}{$\begin{array}{l}\text { DISTÂNCIA } \\
\text { DO EIXO DE } \\
\text { DRENAGEM (m) }\end{array}$} \\
\hline & & cobertura & folhedo & $\begin{array}{l}\text { compac } \\
\text { tação }\end{array}$ & tipo & $\begin{array}{l}\text { estrato } \\
\text { dominan } \\
\text { te }\end{array}$ & $\begin{array}{l}\text { estrato } \\
\text { herbáceo }\end{array}$ & $\begin{array}{l}\text { altura } \\
\text { média } \\
\text { árvores }\end{array}$ & $\begin{array}{l}\text { número } \\
\text { de } \\
\text { estratos }\end{array}$ & & \\
\hline FR & $\begin{array}{l}\text { levemente } \\
\text { inclinada }\end{array}$ & $\begin{array}{l}\text { vegetal } \\
\text { morta }\end{array}$ & 3 & 1 & argiloso & arbóreo & II & $11 \mathrm{~m}$ & 3 & $\mathrm{BC}, \mathrm{C}, \mathrm{F}$ & 40 \\
\hline $\mathrm{CU}$ & plana & $\begin{array}{l}\text { vegetal } \\
\text { viva }\end{array}$ & 3 & 2 & orgânico & herbáceo & $\mathrm{V}$ & $1 \mathrm{~m}$ & 1 & $\mathrm{BC}, \mathrm{C}, \mathrm{F}$ & 5 \\
\hline CC & plana & $\begin{array}{l}\text { vegetal } \\
\text { viva }\end{array}$ & 2 & 1 & arenoso & arbustivo & III & $8 \mathrm{~m}$ & 2 & $\mathrm{BC}, \mathrm{C}, \mathrm{F}$ & 190 \\
\hline $\mathrm{CS}$ & plana & $\begin{array}{l}\text { vegetal } \\
\text { viva }\end{array}$ & 2 & 1 & arenoso & arbóreo & III & $8 m$ & 3 & $\mathrm{BC}, \mathrm{C}, \mathrm{F}$ & 770 \\
\hline FSD & $\begin{array}{l}\text { levemente } \\
\text { inclinada }\end{array}$ & $\begin{array}{l}\text { vegetal } \\
\text { viva }\end{array}$ & 2 & 1 & argiloso & arbóreo & $\mathrm{I}$ & $20 \mathrm{~m}$ & 4 & $\mathrm{BC}, \mathrm{C}, \mathrm{F}$ & 160 \\
\hline $\mathrm{EU}$ & plana & $\begin{array}{l}\text { vegetal } \\
\text { morta }\end{array}$ & 3 & 1 & arenoso & arbóreo & $\mathrm{I}$ & $28 \mathrm{~m}$ & 2 & $\mathrm{BC}, \mathrm{C}, \mathrm{F}$ & 1.500 \\
\hline
\end{tabular}

A análise de agrupamento (figura 44), que relaciona as diferentes fisionomias analisadas com suas características ambientais (registradas na tabela 6) demonstra dois blocos distintos: o das fisisionomias florestais (floresta ripária (FR), floresta semidecídua (FSD) e monocultura de eucalipto (EU)) e o das fisionomias mais abertas (cerrado sensu stricto (CS), campo cerrado $(C C)$ e campo úmido $(C U))$. Entretanto, a monocultura de eucalipto $(E U)$ e o campo úmido (CU) ficaram mais distantes da floresta ripária (FR) e floresta semidecidual (FSD) e do campo carrado (CC) e cerrado sensu stricto (CS), respectivamente, provavelmente devido à distância (no caso dos eucaliptos) ou à proximidade (no caso do campo úmido (CU)) da água.

A análise de correspondência (figura 45), relacionando as características fisiográficas de cada fisionomia estudada (tabela 6) com as diferentes espécies de pequenos mamíferos capturados nessas fisionomias (tabela 3), demostra que o cerrado sensu stricto (CS), a monocultura de eucalipto (EU) e o campo cerrado (CC) aparecem próximos; a fisionomia de campo úmido (CU) aparece isolada, apesar de campestre, muito provavelmente por causa da presença da água, e as fisionomias floresta semidecídua (FSD), floresta ripária (FR) aparecem novamente agrupadas, já que são florestais. Esta análise, portanto, confirma a análise de agrupamento anterior (figura 44). 
FR

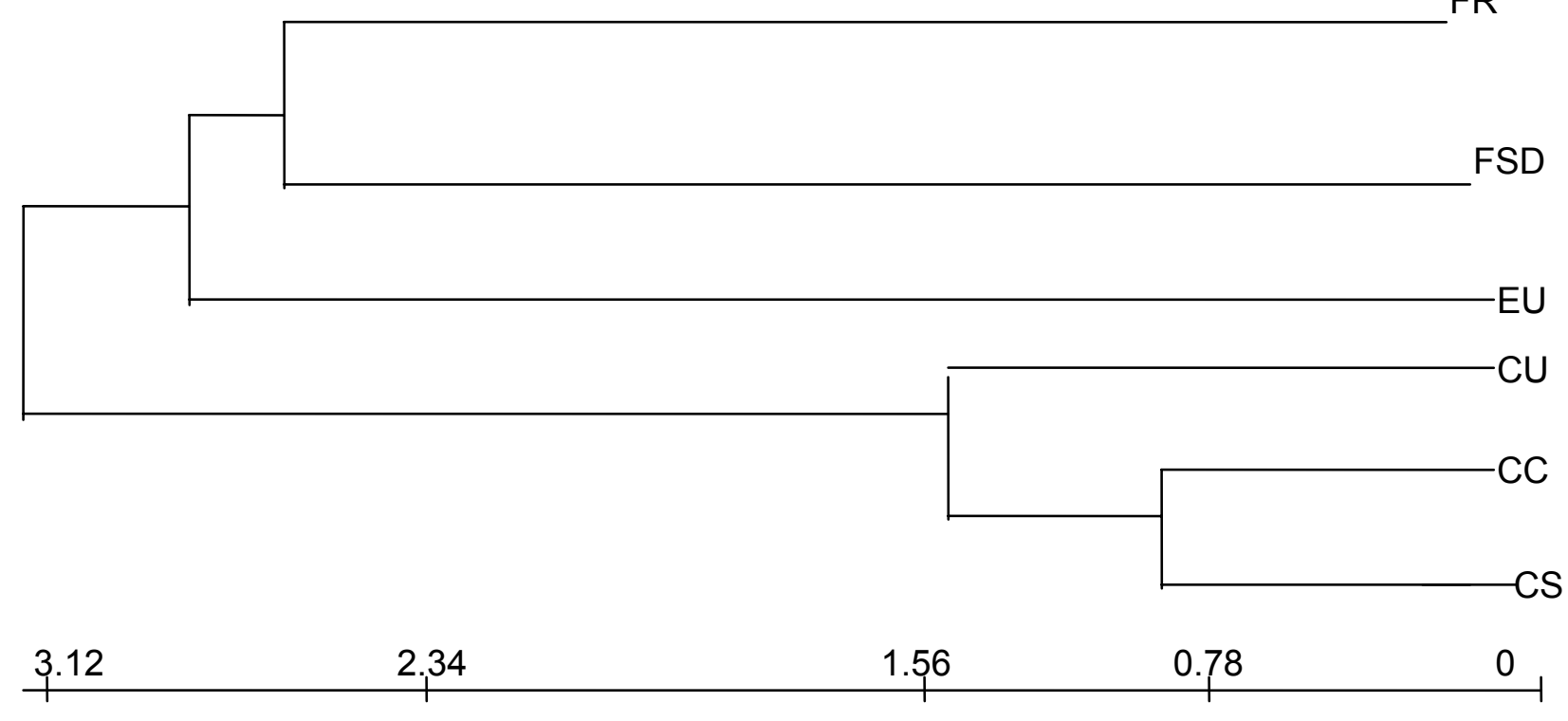

Figura 44: Dendrograma resultante da análise de agrupamento com o método da mínima variância e coeficiente da distância euclidiana,comparando as diferentes fisionomias estudadas com relação às suas características fisiográficas. (FR: floresta ripária, CU: campo úmido, EU: eucalipto, CC: campo cerrado, CS: cerrado sensu stricto, FSD: floresta semidecídua).

Os dados meteorológicos obtidos para a caracterização dos habitats foram coletados em apenas um dia e têm função apenas comparativa entre os microclimas de cada uma das fisionomias amostradas (tabela 7). A figura 46 expressa condições meteorológicas registradas na borda externa da A.R.I.E., no mesmo dia em que se registrou os dados meteorológicos das diferentes fisionomias, para comparação. 


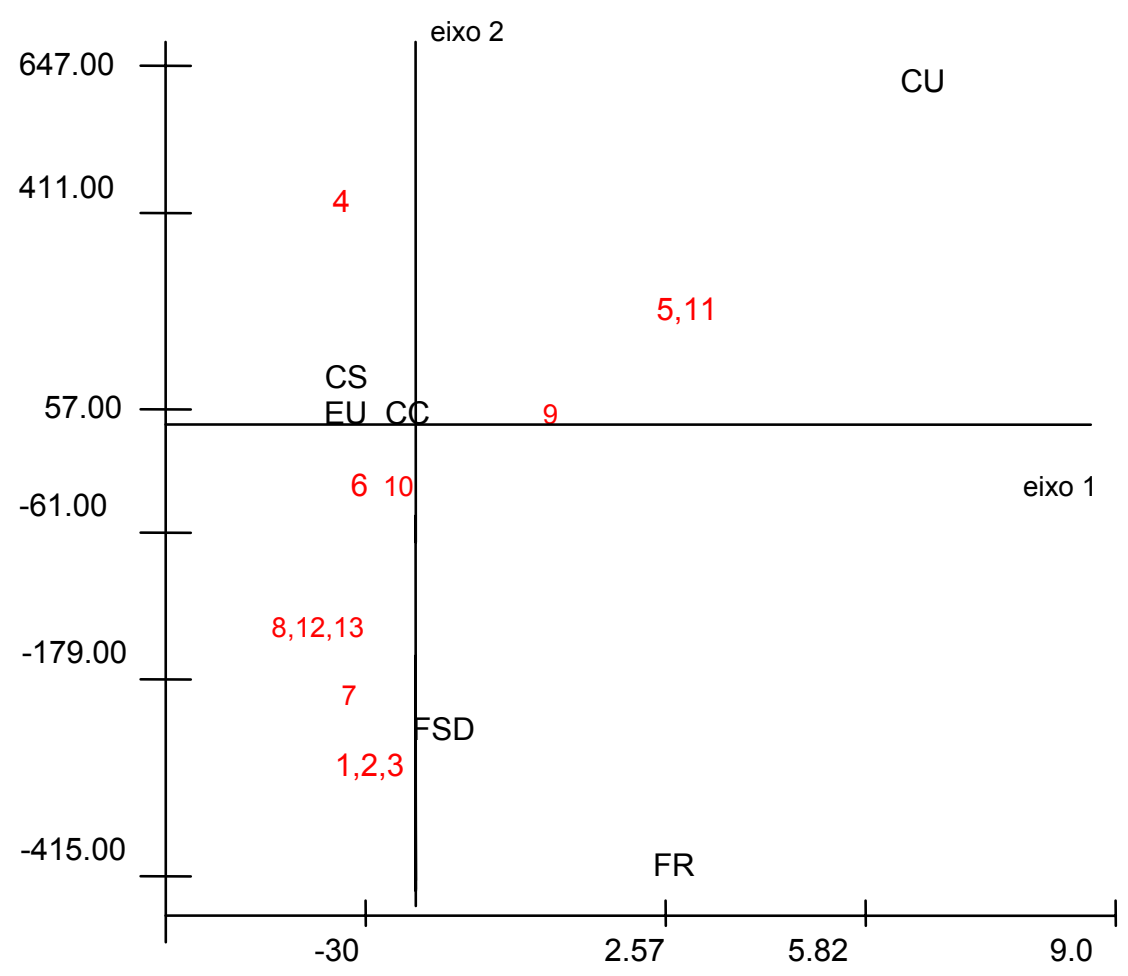

Figura 45: Gráfico de interpretação dos primeiro e segundo eixos resultantes da análise de correspondência com o alogarítimo da média recíproca, para relacionar as fisionomias às capturas dos pequenos mamíferos. (Autovalores: 0.382 -eixo 1e 0.283 - eixo 2)(1: Bolomys lasiurus, 2: Pseudorizomys simplex, 3: Oxymicterus sp, 4: Didelphis albiventris, 5: Gracilinanus microtarsus, 6: Oligoryzomys $s p$, 7: Akodon sp, 8: Nectomys squamipes, 9: Marmosa sp, 10: Calomys sp, 11: Oryzomys sp, 12:

Micoureus cinereus, 13: Philander opossum. FR: floresta ripária, CU: campo úmido, EU: eucalipto, CC: campo cerrado, CS: cerrado sensu stricto, FSD: floresta semidecídua).

As mais baixas temperaturas do ar foram registradas nas fisionomias de monocultura de eucalipto (EU), floresta ripária (FR), floresta semidecídua (FSD), todas florestais. A diferença entre as temperaturas registradas chegou a ser de $4^{\circ} \mathrm{C}$. A mais alta umidade relativa do ar foi encontrada na fisionomia floresta ripária (FR) e floresta semidecídua (FSD), florestais e a primeira, junto ao curso d'água. A monocultura de eucalipto (EU) e o campo cerrado (CC) alcançaram também valores altos. A mais baixa umidade relativa do ar foi encontrada na fisionomia campo úmido $(C U)$, que é totalmente aberta. 
As fisionomias com maior cobertura de copa foram justamente as florestais: floresta ripária (FR) e floresta semidecídua (FSD), enquanto que o campo úmido (CU) não possui nenhuma cobertura de copa.

Tabela 7: Dados meteorológicos, de intensidade luminosa e cobertura vegetal das fisionomias amostradas e no exterior da A.R.I.E. Cerrado Pé-de-Giagante.

\begin{tabular}{|c|c|c|c|c|c|c|c|c|c|}
\hline & \multicolumn{2}{|c|}{$\begin{array}{c}\text { TEMPERATURA } \\
\text { DO AR } \\
\left({ }^{\circ} \mathrm{C}\right)\end{array}$} & \multicolumn{2}{|c|}{$\begin{array}{l}\text { UMIDADE } \\
\text { RELATIVA } \\
\text { DO AR (\%) }\end{array}$} & \multicolumn{3}{|c|}{$\begin{array}{l}\text { INTENSIDADE } \\
\text { LUMINOSA } \\
\text { (Klux) }\end{array}$} & \multirow[t]{2}{*}{$\begin{array}{l}\text { COBERTURA } \\
\text { VEGETAL } \\
\text { ( } \% \text { de área } \\
\text { coberta) } \\
\end{array}$} & \multirow[t]{2}{*}{ HORA } \\
\hline & habitat & $\begin{array}{l}\text { exterior } \\
\text { da } \\
\text { Reserva }\end{array}$ & habitat & $\begin{array}{l}\text { exterior } \\
\text { da } \\
\text { Reserva }\end{array}$ & $\begin{array}{l}\text { habita } \\
\mathrm{t}\end{array}$ & $\begin{array}{l}\text { exterior } \\
\text { da } \\
\text { Reserva }\end{array}$ & $\begin{array}{l}\text { \% luz } \\
\text { habitat/ } \\
\text { exterior }\end{array}$ & & \\
\hline eucalipto & 25.5 & 29 & 76 & 69 & 100 & 280 & 35.7 & 82.6 & $16: 15$ \\
\hline floresta ripária & 25 & 28 & 92 & 70 & 36 & 1200 & 3 & 96.9 & $15: 30$ \\
\hline campo úmido & 29 & 29 & 58 & 57 & 1620 & 4400 & 36.8 & 0 & $14: 40$ \\
\hline campo cerrado & 28 & 29 & 77 & 67 & 1380 & 4400 & 31.4 & 53.1 & $14: 30$ \\
\hline cerrado s.s. & 29 & 29 & 71 & 66 & 360 & 6000 & 6 & 68.8 & $13: 45$ \\
\hline $\begin{array}{l}\text { floresta semi- } \\
\text { decídua }\end{array}$ & 25.5 & 32 & 84 & 70 & 28 & 5200 & 0.5 & 63.2 & $13: 20$ \\
\hline
\end{tabular}

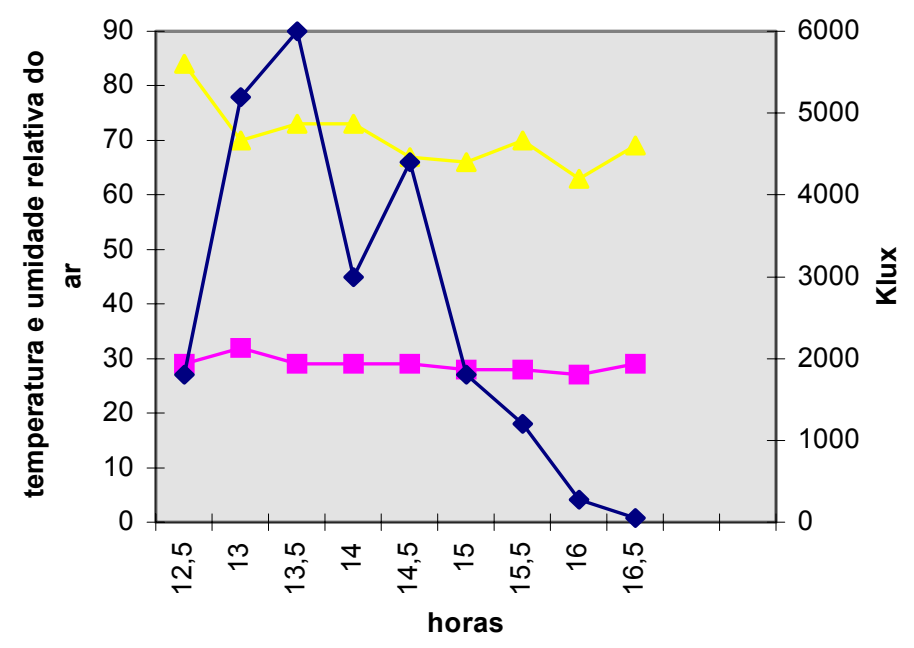

temperatura do ar umidade relativa do ar lux $-10^{3}$

Figura 46: Dados meteorológicos do dia 02/04/98, coletados na borda da A.R.I.E. Cerrado pé-de-Gigante

(Temperatura mínima $29^{\circ} \mathrm{C}$ e máxima $33^{\circ} \mathrm{C}$; Luminiosidade mínima 54 klux e máxima 6000 ; Umidade relativa do ar mínima 63 e máxima 73). 
Foram identificadas, nos limites da Reserva e dentro dela, alguns fatores de perturbação antropogênica. O principal fator de perturbação no entorno da A.R.I.E. Cerrado Péde-Gigante é a rodovia Anhanguera, no seu limite oriental (figura 6). A presença de lixo no limite oriental da reserva é facilmente explicável pela presença da rodovia. As demais faces da A.R.I.E. são delimitadas por estradas de terra, entre os talhões de eucalipto dos reflorestamentos. Estas estradas são menos movimentadas, exercendo uma pressão negativa menor sobre a Reserva, uma vez que, com um menor trânsito de veículos, diminuem as possibilidades de atropelamento de animais, acúmulo de lixo, riscos de incêndio e a presença de caçadores e curiosos. Com relação aos atropelamentos, a grande maioria daqueles registrados no período deste estudo ocorreu na rodovia Anhanguera e suas vicinais asfaltadas, de maior movimento.

A presença de agrotóxicos utilizados pelas empresas de reflorestamento também é uma perturbação significativa, uma vez que os animais entram em contato com estas substâncias.

No interior da A.R.I.E., algumas perturbações chamam a atenção, como, por exemplo, a presença constante de gramíneas exóticas, que foram plantadas para formação de pasto por criadores de gado que arrendavam as terras da Usina Vassununga, antes da área tornar-se uma unidade de conservação. Existem também caixas de abelhas clandestinas escondidas no meio do cerrado, sempre no limite com o eucaliptal, colocadas por pessoas da região para comercialização de mel.

O corte dos eucaliptos no entorno da A.R.I.E. também constitui-se num forte fator de perturbação, pois, apesar de ocorrer em intervalos de sete anos, em média, a retirada da cobertura vegetal e de abrigo à fauna, a presença das máquinas e dos funcionários, que inevitavelmente fazem muito barulho e deixam lixo no local, são fatores de forte perturbação naquela área durante o período de corte. Estas perturbações concentram-se em pontos determinados da A.R.I.E., plotados conforme a figura 47.

Em todos os pontos de coleta, em cada um dos habitats deste estudo havia um certo grau de perturbação causado, pelo menos, pela própria presença da trilha. Nas fisionomias cerrado sensu stricto (CS), campo cerrado (CC) e campo úmido (CU), a presença de gramíneas exóticas era bastante grande. A fisionomia floresta ripária (FR) encontravam-se em evidente estado de recuperação em decorrência de um fator de perturbação, provavelmente climática, como as geadas que atingiram a região em 1994. Todas as fisionomias amostradas encontavam-se dentro do sistema de trilhas da A.R.I.E., por onde circulavam esta e outras equipes de pesquisa. Estas trilhas, por si só, já são um fator de 
perturbação, principalmente por facilitarem a invasão de gramíneas exóticas, principalmente nas fisionomias mais abertas.

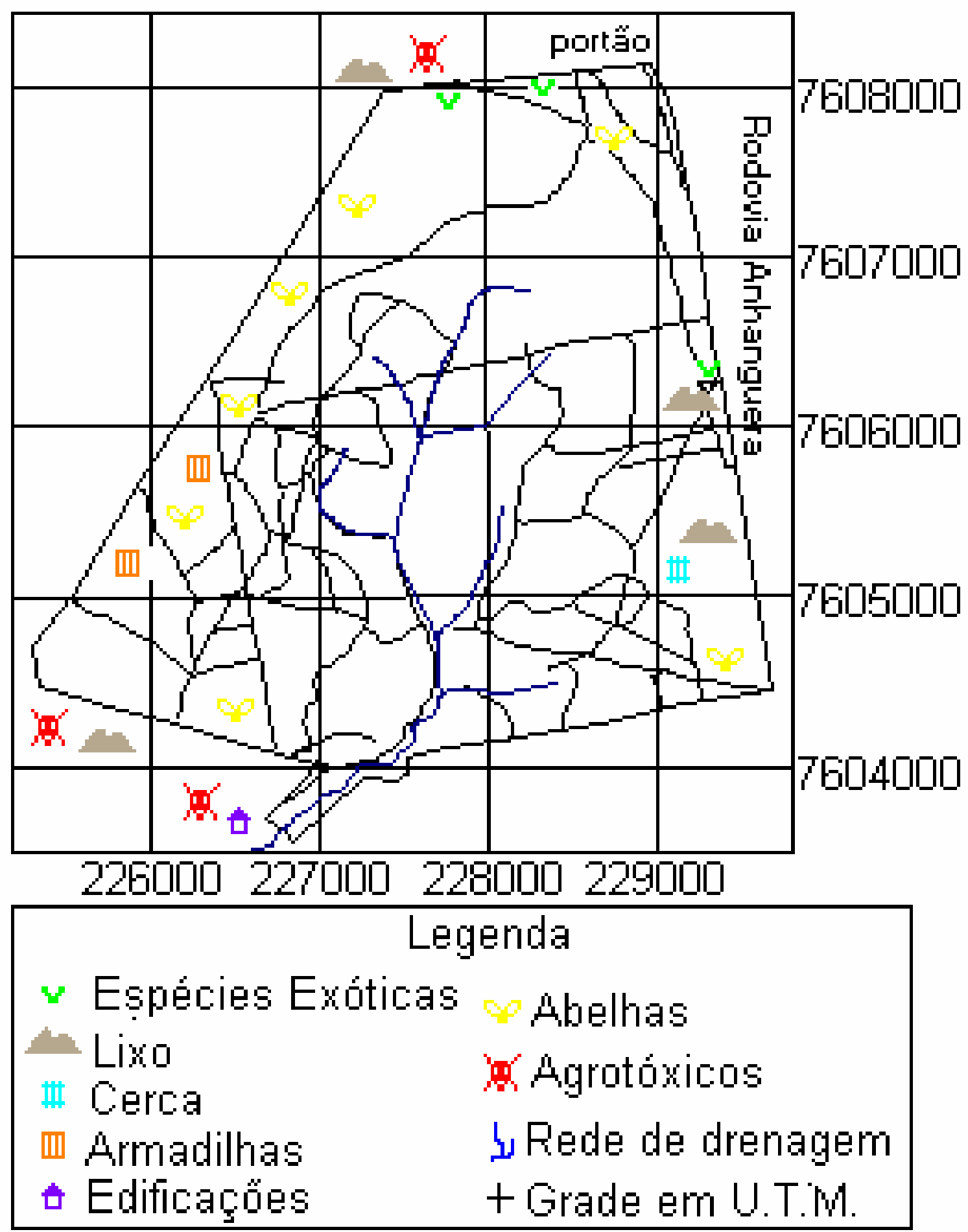

Figura 47: Localização das principais perturbações antropogênicas do interior e no entorno imediato da A.R.I.E. Cerrado Pé-de-Gigante (Fonte:Pivello, 1996). 


\subsection{Levantamento histórico da fauna:}

As entrevistas realizadas com a população local permitiram verificar que a região mudou bastante nos últimos 30 anos, pois, anteriormente, havia muitas áreas de cerrado e fazendas de café e, hoje, a região encontra-se com predomínio de monoculturas de cana e de eucalipto (tabela 8).

Os entrevistados revelaram que se retirava muita madeira do cerrado para servir de combustível às usinas de açúcar e para a construção da estrada de ferro Mogiana. O gado era criado solto no cerrado e seus criadores costumavam semear o capim-gordura (Melinis minutiflora) em meio à vegetação nativa, a fim de fornecer maior quantidade de forrageiras aos animais. A grande maioria dos entrevistados acreditava, inclusive, que o capim-gordura fosse uma gramínea nativa do cerrado.

Tabela 8: Opinião da população local sobre a influência dos reflorestamentos de eucalipto na mastofauna da região de Santa Rita do Passa-Quatro e Luiz Antônio, SP (\%).

\begin{tabular}{|c|c|c|}
\hline RESPONDENTES (\%) & CAUSAS ( $\%$ de $A)$ & INFLUÊNCIA (\% de C e D) \\
\hline \multirow{4}{*}{$\begin{array}{l}\text { A- ÁREA MUDOU } \\
94,7\end{array}$} & \multirow{2}{*}{$\begin{array}{c}\text { C- CANA -DE-AÇÚCAR } \\
44,4\end{array}$} & $\begin{array}{c}\text { AUMENTARAM OS ANIMAIS } \\
0\end{array}$ \\
\hline & & $\begin{array}{l}\text { DIMINUIRAM OS ANIMAIS } \\
57,9\end{array}$ \\
\hline & \multirow{2}{*}{$\begin{array}{c}\text { D- REFLORESTAMENTOS } \\
55,5\end{array}$} & $\begin{array}{c}\text { AUMENTARAM OS ANIMAIS } \\
30\end{array}$ \\
\hline & & $\begin{array}{l}\text { DIMINUIRAM OS ANIMAIS } \\
70\end{array}$ \\
\hline \multicolumn{3}{|l|}{$\begin{array}{c}\text { B - ÁREA NÃO MUDOU } \\
5,3\end{array}$} \\
\hline NÚMERO TOTAL DE & RESPONDENTES & \\
\hline
\end{tabular}


Todos os entrevistados disseram que frequentemente avistam animais na região (tabela 9 e figura 48), apesar de afirmarem que a quantidade de animais diminuiu com a degradação do cerrado, acarretando, inclusive o desaparecimento de algumas espécies, como a ema (Rhea americana), a onça-pintada (Panthera onca) e o queixada (Tayassu pecari). Além disso, $48 \%$ dos entrevistados afirmaram já ter encontrado animais atropelados, a maioria na Rodovia Anhanguera, e alguns nas estradas vicinais.

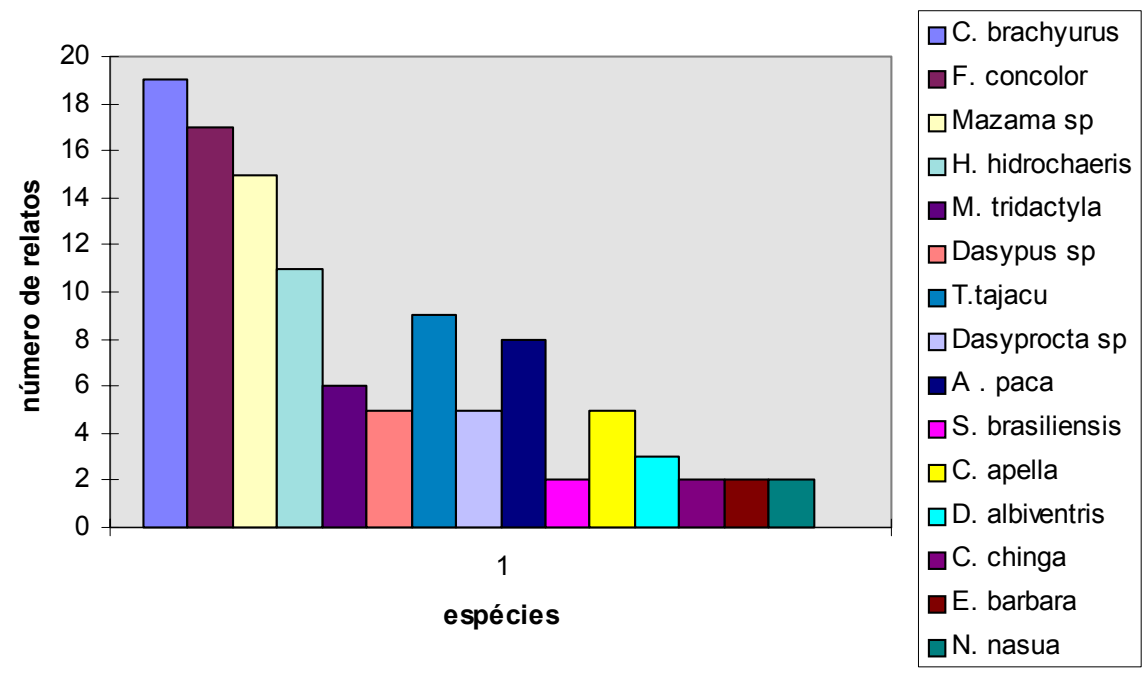

Figura 48: Espécies avistadas pela população local, conforme dados obtidos com as entrevistas realizadas.

Grande parte dos entrevistados (52,6\%) vê caçadores na região, principalmente nas áreas de reflorestamento de eucalipto (apesar da fiscalização), que paracem ter mais animais que as monoculturas de cana-de-açúcar. A maneira mais utilizada para praticar esta caça é com o uso da espingarda, seguida por cachorros e armadilhas (tabela 9).

Tabela 9: Prática da caça pela população na região da A.R.I.E. Cerrado Pé-de-Gigante.

\begin{tabular}{|c|c|c|}
\hline RESPONDENTES (\%) & LOCAL (\% de A) & TIPO DE ARMA (\%de A) \\
\hline \multirow{3}{*}{ A - VÊ CAÇADOR } & C- REFLORESTAMENTO & ESPINGARDA \\
52,6 & 90 & 80 \\
\cline { 2 - 3 } & D- CANA-DE-AÇÚCAR & OUTROS \\
& 10 & 20 \\
\hline B - NÃO VÊ CAÇADOR & 47,4 \\
\hline NÚMERO TOTAL DE & RESPONDENTES 19 \\
\hline
\end{tabular}


O animal preferido pelos caçadores é o cateto, seguido de veado, capivara e tatu (figura 49), pois são estes animais que posuem a carne mais apreciada para alimentação.

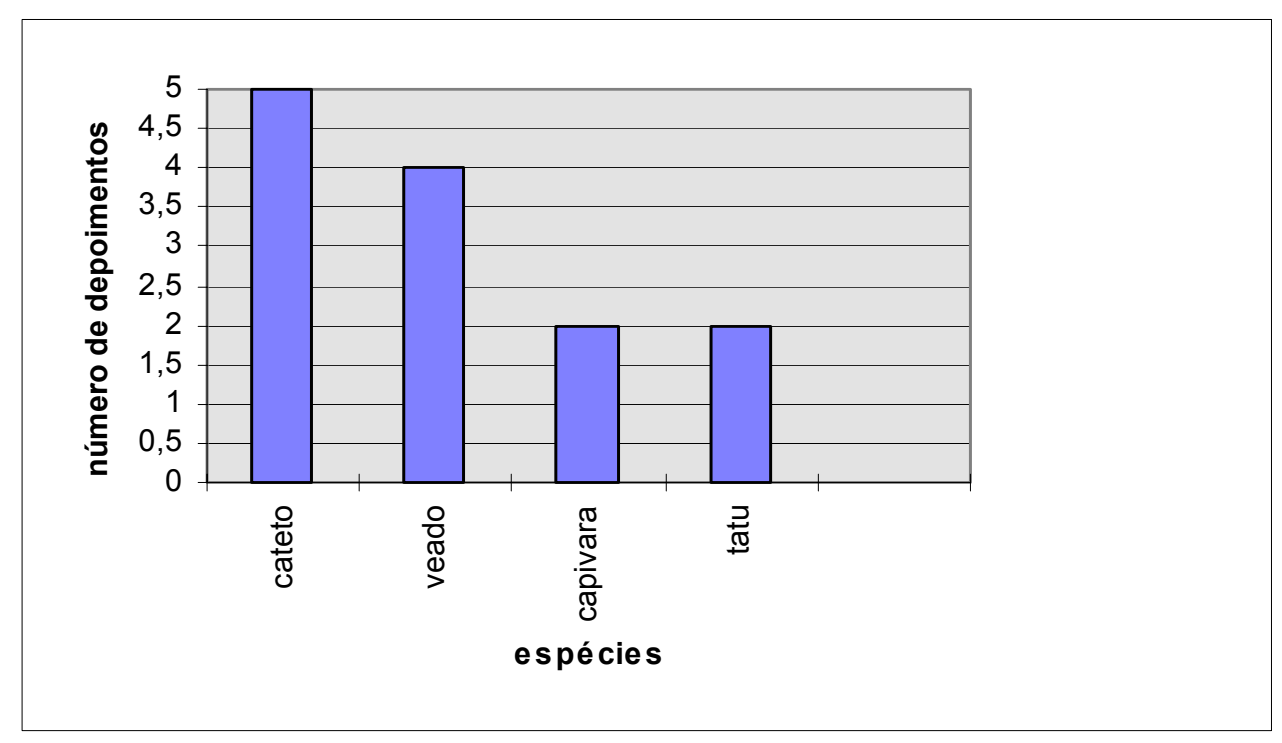

Figura 49: Espécies mais caçadas pela população local.

Finalmente, a respeito dos animais silvestres apreendidos por diversos motivos pela polícia florestal da região e reintroduzidos na região da A.R.I.E., principalmente na Estação Ecológica de Jataí, somente aqueles que são ou foram funcionários do Instituto Florestal $(15,8 \%)$ têm conhecimento do fato. Documentos examinados fornecidos pelo Instituto Florestal na Estação Ecológica de Jataí forneceram uma lista de répteis, aves e mamíferos reintroduzidos na região, porém, apenas os maíferos, objetivo deste estudo, foram compilados para a tabela 10. Apesar da grande maioria dos entrevistados concordarem que o reflorestamento de eucalipto é um dos responsáveis pelas transformações ocorridas na região, $94,7 \%$ deles acreditam que o eucalipto é muito melhor para a fauna do que a monocultura de cana-de-açúcar, pois vêm a silvicultura de eucalipto como uma floresta protegida, onde os animais de grande porte podem viver a salvo de caçadores e da destruiçào do seu habitat, uma vez que a fiscalização contra caça nessas áreas é efetiva. 
Tabela 10: Espécies de mamíferos reintroduzidas na Estação Ecológica de Jataí, Luis Antônio - SP.

\begin{tabular}{|c|c|c|c|}
\hline DATA & ORIGEM & QUANTIDADE & ESPÉCIE \\
\hline $23 / 07 / 84$ & desconhecida & 07 & T. peccary \\
\hline $24 / 07 / 84$ & desconhecida & 04 & T. peccary \\
\hline $21 / 08 / 84$ & Bosque Municipal de Rib.Preto & 01 & H. hidrochaeris \\
\hline $21 / 08.84$ & Bosque Municipal de Rib. Preto & 02 & Didelphis $s p$ \\
\hline $21 / 08 / 84$ & Bosque Municipal de Rib. Preto & 02 & N. Nasua \\
\hline $24 / 08 / 84$ & Bosque municipal de Rib. Preto & 01 & F. concolor \\
\hline $16 / 09 / 85$ & Bosque Municipal de Rib. Preto & 01 & H. hidrochaeris \\
\hline $16 / 09 / 85$ & Bosque Municipal de Rib.Preto & 01 & T. tetradactyla \\
\hline $16 / 09 / 85$ & Bosque Municipal de Rib. Preto & 01 & D. thous \\
\hline $16 / 06 / 87$ & Bosque Municipal de Rib. Preto & 01 & Felis sp \\
\hline $16 / 06 / 87$ & Bosque Municipal de Rib. Preto & 01 & Procyon sp \\
\hline $18 / 09 / 87$ & Bosque Municipal de Rib. Preto & 01 & H. hidrochaeris \\
\hline $19 / 10 / 87$ & Bosque Municipal de Rib. Preto & 01 & C. brachyurus \\
\hline $04 / 05 / 88$ & Bosque Municipal de Rib. Preto & 03 & T. peccary \\
\hline $12 / 07 / 88$ & Bosque Municipal de Rib.Preto & 03 & C. apella \\
\hline $25 / 07 / 88$ & Bosque Municipal de Rib. Preto & 02 & D. thous \\
\hline $25 / 10 / 87$ & Bosque Municipal de Rib. Preto & 01 & T. tetradactyla \\
\hline $03 / 10 / 88$ & Cravinhos - SP & 01 & T. tetradactyla \\
\hline 03/01/89 & Bosque Municipal de Rib.Preto & 01 & Allouatta sp \\
\hline $26 / 08 / 89$ & Parque Ecológico de S. Carlos & 08 & macacos ?? \\
\hline $28 / 09 / 89$ & Parque Ecológico de S. Carlos & 05 & macacos ?? \\
\hline $01 / 09 / 89$ & particular de Guatapará - SP & 01 & P. brasiliensis \\
\hline $11 / 10 / 89$ & particular de Sertãozinho - SP & 01 & C. brachyurus \\
\hline $10 / 11 / 89$ & particular de São Simão - SP & 01 & canídeo ??? \\
\hline $20 / 11 / 89$ & particular de São Simão - SP & 01 & D. thous \\
\hline $13 / 03 / 90$ & Bosque Municipal de Rib. Preto & 01 & Felis $s p$ \\
\hline $17 / 05 / 90$ & desconhecida & 01 & D. thous \\
\hline $09 / 11 / 90$ & desconhecida & 01 & Mazama guazoubira \\
\hline $14 / 01 / 91$ & particular de Serrana - SP & 01 & H. hidrochaeris \\
\hline $14 / 02 / 91$ & desconhecida & 01 & H. hidrochaeris \\
\hline $25 / 02 / 92$ & particular de Ribeirão Preto - SP & 01 & H. hidrochaeris \\
\hline $28 / 09 / 93$ & Bosque Municipal de Rib. Preto & 01 & C. apella \\
\hline $07 / 01 / 94$ & desconhecida & 01 & F. concolor \\
\hline $25 / 05 / 94$ & particular de Luis Antônio - SP & 01 & C. apella \\
\hline
\end{tabular}




\section{Discussão:}

Este estudo proporcionou o conhecimento da mastofauna da A.R.I.E. Cerrado Pé-de-Gigante e dos ambientes em que vivem, bem como algumas inferências sobre a qualidade que a região oferece à sobrevivência da fauna nativa.

A fisionomia de cerrado sensu stricto (CS) foi a que apresentou uma maior diversidade de pequenos mamíferos $\left(H^{\prime}=1,88\right)$, enquanto que a floresta semidecídua $(F S D)$ e a floresta homogênea de eucaliptos (EU) tiveram seus índices de diversidade ( $\left.H^{\prime}\right)$ muito próximos $\left(H^{\prime}=1,09\right.$ e 1,00, respectivamente). A floresta ripária $(F R)$ apresentou uma diversidade menor que o cerrado sensu stricto (CS) $\left(H^{\prime}=1,78\right.$ e $H^{\prime}=1,88$, respectivamente), apesar de apresentar uma maior riqueza de espécies da fauna amostrada, indicando haver a dominância da espécie Oligoryzomys sp. O campo úmido (CU), apesar de apresentar espécies exclusivas, apresentou um índice de diversidade próximo ao do campo cerrado (CC) $\left(H^{\prime}=1.56\right.$ e 1.50, respectivamente) (tabela 3).

Em seus estudos, comparando floresta ripária, floresta semidecídua e campo cerrado, Talamoni (1996) encontrou um maior índice de diversidade na floresta ripária, floresta semidecídua e o campo cerrado apresentaram H' muito próximos e inferiores ao da floresta ripária, como neste estudo. Vieira (1989) observou no cerrado de Itirapina (SP) uma riqueza específica de pequenos mamíferos muito menor do que a observada na A.R.I.E. Cerrado Pé-deGigante, apesar daquela ser uma área de cerrado próxima à deste estudo. Uma hipótese para tal diferença poderia ser em virtude de todos esses fragmentos de cerrado, no Estado de São Paulo, representarem a distribuição periférica do bioma, sabendo-se que as espécies têm densidades menores e mais variáveis em áreas periféricas do que na área central (Gibbs et al., 1983).

Observou-se que Oligoryzomys sp apareceu em todas as fisionomias de cerrado e na floresta homogênea de eucaliptos. Também Calomys sp apareceu em todas fisionomias estudadas com exceção da floresta homogênea de eucaliptos. Estes dados reforçam a observação de Fleming (1975, apud Stallings, 1990), que sugerem que uma ou duas espécies usualmente dominam uma dada comunidade de pequenos mamíferos. O roedor Nectomys squamipes aparece somente na fisionomia intimamente relacionadas à água, paralelas ao córrego (floesta ripária $(\mathrm{FR})$ ), já que é um roedor semi-aquático, restrito à beira da corrente d'água (Alho, 1994). O campo úmido (CU) vem se mostrando a fisionomia onde ocorrem os pequenos mamíferos mais raros, como Bolomys lasiurus, Pseudoryzomys simplex, 
Oxymycterus sp. Tais resultados corroboram dados bibliográficos que afirmam que Bolomys lasiurus é um roedor comum em áreas perturbadas e com alta ocorrência de gramíneas, uma vez que se alimenta das sementes destas (Alho, 1994). De fato, a área do campo úmido (CU) é fortemente dominada por gramíneas do gênero Adropogon . A ocorrência de Oxymycterus sp, que é característica de brejos e campos limpos (Nitikman \& Mares, 1987), no campo úmido (CU), justifica-se por esta ser uma área que permanece alagada durante alguns meses do ano.

O marsupial Didelphis albiventris parece preferir as formações que apresentem algumas árvores (campo cerrado [CC], floresta homogênea de eucaliptos [EU]), além de ser o único marsupial a ocorrer na floresta de eucaliptos (EU), concordando com a afirmação de Charles-Dominique (1983) de que estes marsupiais se comportam como " $r$ " estrategistas, ou seja, são generalistas e pioneiros, bem adaptados a ambientes instáveis e de matas secundárias. Os marsupiais Marmosa sp e Gracilinanus microtarsus parecem preferir fisionomias mais arbustivas de cerrado (cerrado sensu stricto [CS]), já que possuem hábito arborícola (Alho, 1994). Além disso, a abundância destes marsupiais parece aumentar nos estágios de sucessão mais avançados e com a heterogeneidade estrutural (Paglia et al, 1995).

Finalmente, o único exemplar do marsupial Philander opossum avistado encontrava-se numa fisionomia florestal (floresta ripária [FR]). De acordo com Alho (1994) a espécie tem preferência por mata ciliar e campo úmido.

Muito poucos indivíduos marcados foram recapturadas neste estudo: um exemplar de Oligoryzomys sp e um exemplar de Calomys sp, na floresta ripária (FR) e dois exemplares de Gracilinanus microtarsus, no cerrado sensu stricto (CS). Os animais não possuíam marcações individuais, portanto pode-se concluir somente que as estações de pitfall, onde foram recapturados, encontravam-se na área de vida destes indivíduos. O pitfall localizado no cerrado sensu stricto (CS) capturou somente indivíduos da espécie G. microtarsus, sendo vários indivíduos de uma só vez no mesmo balde do pitfall, sugerindo que, muito provavelmente, pertenciam ao mesmo grupo.

A comparação entre as fisionomias amostradas através da análise de agrupamento, com relação aos mamíferos nelas capturados, aponta uma grande semelhança entre a floresta homogênea de eucaliptos (EU) e o campo cerrado (CC), que se deveu, principalmente, ao fato de se ter capturado o marsupial Didelphis albiventris em ambas. A floresta ripária (FR) e o campo úmido (CU) aparecem próximos pelo fato de também apresentarem exemplares que só ocorreram nestas fisionomias (Nectomys squamipes na floresta ripária (FR) e Oxymycterus sp, Bolomys lasiurus, Pseudoryzomys simplex no campo 
úmido (CU). O cerrado sensu stricto (CS) aparece também mais isolado, principalmente pelo fato da alta captura de Gracilinanus microtarsus em sua estação de pitfall.

No que diz respeito à caracterização dos habitats, Bohác \& Fuchs (1991) afirmam que as características sinecológicas da comunidade são o reflexo da relação entre a comunidade e o meio ambiente, e que os fatores que determinam a estrutura de uma comunidade animal fazem dela um bioindicador da deterioração da paisagem. A análise de agrupamento das características fisiográficas da A.R.I.E. Cerrado Pé-de-Gigante (figura 44) aproximou fisionomias como floresta semidecídua (FSD) e floresta ripária (FR), já que são florestais, isto é, apresentam o mesmo número de estratos, com dominância de indivíduos arbóreos e a altura média de suas árvores assemelham-se, além de possuírem muitas características relacionadas ao solo e à sua cobertura. Apesar de ter menor estratificação e árvores bem mais altas, a floresta homogênea de eucaliptos (EU) manteve-se, na análise de agrupamento próxima das duas florestas anteriores devido às características inerentes a um ambiente florestal, como o tipo de cobertura do solo e a dominância do estrato arbóreo. O cerrado sensu stricto (CS) e o campo cerrado (CC) foram agrupados devido à sua formação herbáceo-arbustiva, promovendo uma cobertura vegetal muito semelhante, sobre o solo arenoso. Por fim, a fisionomia campo úmido (CU) aparece isolada das demais devido à presença constante da água, pois é um ambiente bastante alagadiço. Esta grande umidade reflete no seu tipo de solo, que é altamente orgânico e que não se encontra em nenhuma outra fisionomia, além de possuir uma cobertura exclusivamente herbácea. Esta análise revela dois grupos distintos: o dos cerrados e o das florestas, indicando que a estratificação é muito importante na determinação das espécies de pequenos mamíferos que habitam esses ambientes, pois influi amplamente nas outras características do ambiente.

A relação entre estas características fisiográficas e as espécies de pequenos mamíferos capturadas em cada uma das fisionomias, obtida na análise de correspondência (figura 45), distribui as fisionomias ao longo do eixo 1, num gradiente de umidade, sendo então a presença água o grande responsável pela distribuição diferencial de algumas espécies. No eixo 2, a ordenação das fisionomias deu-se num gradiente de estratificação. Os animais capturados estão distribuídos ao longo do eixo 1 de acordo com sua relação e dependência da água e, no eixo 2, com seu hábito arborícola (estratificação da vegetação). Considerando estes dados, a fisionomia campo úmido $(\mathrm{CU})$ tem valor mais alto no eixo 1 , devido à sua proximidade da nascente do curso d'água, além de ser uma área altamente alagável. Em seguida, aparece a floresta ripária (FR) e a floresta semidecídua (FSD), e finalmente os cerrados (campo cerrado [CC], cerrado sensu stricto [CS]) e o eucalipto (EU), que é a fisionomia mais distante da água. No eixo 2, campo úmido (CU) também apresenta o valor 
mais alto, pois possui menor estratificação, e as fisionomias florestais de floresta ripária (FR) e floresta semidecídua (FSD), por outro lado, com maior estratificação. Considerando-se as espécies agrupadas por meio desta análise de correspondência (CA), verificou-se que eles se concentram em três grupos: os de hábito campestre $(1,2,3)$, os de hábito arborícola $(5,12,13)$ e os generalistas $(4,6,10)$.

Muitos estudos mostram que a composição de espécies e abundância relativa de pequenos mamíferos numa comunidade pode ser explicada pela estrutura do habitat e sua heterogeneidade (Dueser \& Shugart, 1978; August, 1984 apud Fonseca, 1989). Em relação às comunidades tropicais, alguns estudos (August, 1983; Charles-Dominique, 1981; Emmons, 1980 apud Talamoni, 1996), mostraram que a riqueza de espécies aumenta com o aumento da complexidade estrutural da vegetação. No Brasil, alguns estudos sobre riqueza e diversidade de pequenos mamíferos e seus padrões de utilização do habitat têm também demonstrado a estreita relação entre diversidade e complexidade da vegetação (Fonseca \& Redford, 1984; Alho et al., 1986; Fonseca, 1989).

Alho (1994) afirma que cada habitat do cerrado tem uma diversidade e densidade de populações características, de acordo com o grau de complexidade de estrutura de cada habitat. Lacher \& Alho (1989) afirmam que a distribuição e diversidade de espécies animais no ambiente de cerrado são influenciadas pela composição de recursos ecológicos, que varia de local para local, na forma de um mosaico desses recursos. Recursos que, em outras palavras, delineiam a estrutura da comunidade animal no bioma. Neste estudo, a caracterização dos habitats permitiu a verificação de uma maior densidade de pequenos mamíferos capturados e até mesmo um maior índice de diversidade H' ou nas fisionomias com maior complexidade estrutural, isto é, maior riqueza de espécies vegetais e a presença marcante de um estrato herbáceo e um arbóreo (o cerrado sensu stricto [CS], seguido da floresta ripária $[F R]$ ) ou quando o ambiente era marcadamente influenciado pela água ( a floresta ripária [FR] e o campo úmido [CU]). A floresta semidecídua (FSD), apesar de sua alta estratificação e da diversidade de espécies vegetais e de habitats, pode ter apresentado, nesse estudo, baixa diversidade por dois motivos: porque não se amostrou a fauna arborícola, sendo que é um ambiente arbóreo, e porque constituiu uma pequena mancha na área de estudo, restringindo a disponibilidade deste habitat às espécies e sofrendo maior efeito de borda, como será discutido adiante. Retoma-se então os resultados da análise de correspondência (figura 45), onde os eixos são definidos pela estratificação e pela presença de água.

No que diz respeito ao fato de o número de roedores capturados ser muito maior que o número de marsupiais (figura 30 ), dados bibliográficos confirmam que, com raras 
exceções, este é realmente o padrão; Dias, (1982) capturou três vezes mais roedores que marsupiais; Avila-Pires (1978) capturou 245 roedores e 40 marsupiais; Davis (1945) capturou 58 marsupiais e 285 roedores apud Stallings (1989).

A análise da flutuação sazonal anual da densidade dos pequenos mamíferos amostrados (figura 32) nos permite concluir que os maiores valores de capturas foram encontrados durante o período seco. As causas que podem promover estas flutuações ainda são discutidas. No Brasil, são poucos os estudos a longo prazo que observaram flutuações multianuais (Cerqueira, et al., 1983; Stallings, 1989 apud Talamoni, 1996). A maioria dos estudos têm observado flutuações sazonais para muitas espécies, as quais coincidem com os resultados encontrados neste estudo, ou seja, maior sucesso de captura na época seca, pois é nesta época que os recursos alimentares ficam mais escassos, causando um aumento na movimentação dos animais em busca de alimento fazendo que a isca das armadilhas torne-se mais atrativa (Alho et al, 1986; Borchert \& Hansen, 1983; Dietz, 1983; Fonseca \& Kierluff, 1989; Talamoni, 1990; Valle et al ,1982 apud Talamoni, 1996) (Vieira, 1989).

Não foi observada relação significativa entre o sucesso de captura dos pequenos mamíferos e o período de floração e frutificação das espécies vegetais do cerrado sensu lato (figura 33). Também não se observou alguma relação entre a deciduidade foliar e diminuição da cobertura de dossel com essas capturas.

Quanto aos tipos de armadilhas utilizadas, apesar de pouco comum para pequenos mamíferos, o pitfall mostrou-se um método bastante eficiente e complementar às gaiolas, uma vez que somente duas espécies (Akodon sp e Bolomys lasiurus) foram capturadas pelos dois tipos de armadilhas. As demais espécies caíram ou só nas gaiolas ou só nos pitfalls, dependendo do seu tamanho, sendo que as maiores eram capturadas nas gaiolas, como o roedor Nectomys squamipes e o marsupial Didelphis albiventris, cujos corpos medem, em média, $16 \mathrm{~cm}$ e $28 \mathrm{~cm}$, respectivamente. As menores espécies foram capturadas preferencialmente nos pitfalls, como o roedor Oligoryzomys sp e o marsupial Marmosa sp, cujos corpos medem, em média, $6,17 \mathrm{~cm}$ e $5 \mathrm{~cm}$ respectivamente. $O$ índice de similaridade de Jaccard Isj $(I s j=0.17)$ obtido, corrobora a idéia de que os métodos são complementares e não exclusivos. Porém, é conveniente salientar que o sucesso de captura das armadilhas do tipo gaiola foi muito baixo neste estudo $(0,35 \%)$, comparado com a bibliografia disponível. Entretanto, nos estudos de Stallings (1989), apresentando resultados de diversos pesquisadores em regiões de mata e de savana, o sucesso das coletas em savanas invariavelmente se mostrou menor (August, obteve, nas savana da Venezuela, 0,1\%; Borchert 
\& Hanson, obtiveram no cerrado do Brasil, 3,5\%; e novamente August, obteve 1,9\% na savana da Venezuela [apud Stallings, 1989]).

Acredita-se que, o baixo sucesso de captura encontrado neste estudo deveuse à um problema metodológico, envolvendo o bom funcionamento das armadilhas, uma vez que estas dificilmente eram desarmadas por animais muito leves, e ainda possuíam uma trama de metal que permitia a passagem daqueles muito pequenos (aproximadamente $1 \mathrm{~cm} \times 1 \mathrm{~cm}$ ). Algumas tentativas para solucionar estes problemas foram feitas, como utilizar rodelas de maidioca na isca, o que dificultava sua retirada do gancho existente na extremidade interna da armadilha, mantendo assim o animal mais tempo na plataforma que acionava a armadilha; o gatilho que fechava a porta era lubrificado com óleo de máquina sempre que a armadilha era armada, a fim deste tornar-se mais sensível. McManus \& Nellis, 1972, afirmam que, em coletas realizadas na Califórnia, com uma metodologia muito semelhante à utilizada neste estudo, obtiveram um baixo sucesso de captura, devido a problemas com o "gatilho" que fecha a porta das gaiolas por causa do peso dos pequenos mamíferos, que frequentemente roubavam a isca sem desarmar a armadilha, além de serem capazes de fugir pela malha das armadilhas, como neste caso. Pesquisadores comparando diversas armadilhas do tipo gaiola afirmaram que nenhuma delas é realmente eficiente para a captura de pequenos roedores, com algumas ressalvas para as armadilhas do tipo Sherman, não utilizadas neste estudo.

Como a fragmentação de habitats naturais leva a uma perda da biodiversidade local (Andrèn, 1994), é necessário considerarmos aqui também o efeito de "tamanho de área", isto é, se o tamanho de cada uma das fisionomias está ou não interferindo na diversidade de espécies lá encontradas. A redução de diversidade devida à fragmentação ocorre por dois processos distintos, que agem em tempos diferentes. O primeiro, a curto prazo, é a própria redução da área do habitat em questão que, por simples efeito de amostragem, leva os fragmentos a terem menos espécies que uma área contínua. O outro processo, que atua a longo prazo, é a insularização, ou seja, o isolamento do fragmento natural em meio a paisagens antrópicas (Fernandez, 1997).

Existe um padrão empírico das relações espécie-área, ou seja, geralmente há uma relação estreita entre a área ocupada por uma comunidade e sua riqueza em espécies (McGuiness, 1984, apud Fernandez, 1997). Talvez seja por este motivo que fisionomias florestais, heterogêneas e complexas, como a floresta semidecídua (FSD), apresentaram um índice de diversidade ( $\mathrm{H}^{\prime}$ ) tão baixo, já que FSD é uma mancha muito pequena na borda da Reserva. Além disso, é preciso salientar que as formações florestais, como floresta ripária (FR) e floresta semidecídua (FSD), possuem uma grande quantidade de lianas e estas afetam 
significantemente a dinâmica da floresta, podendo até impedir a recomposição do dossel, diminuindo sensivelmente a qualidade do fragmento (Viana, 1997).

Van Horne (1983) define como qualidade ambiental o tamanho mínimo viável de uma população que sobreviverá no fragmento. O conceito de população efetiva viável é fundamental na teoria de conservação, porque a maioria das populações objeto de esforços conservacionistas tendem a ser relativamente pequenas e isoladas (Santos Filho, 1995), aumentando muito a probabilidade de endocruzamento, a perda de alelos espécíficos, diminuindo a variância de caracteres quantitativos (Simberloff, 1988). Desta forma, é hoje consenso que genética e demografia devam ser consideradas em conjunto e para cada espécie, na definição do tamanho mínimo viável de uma população (Shaffer, 1981). Também é importante ser lembrada a estocasticidade demográfica para a dinâmica de pequenas populações, que causa variações casuais nas taxas vitais - natalidade e mortalidade - e que podem afetar de maneira irremediável uma população (Santos Filho, 1995).

A análise dos padrões de ocorrência dos grandes e médios mamíferos nos distintos tipos de habitats (tabela 1 ) revelou uma distribuição diferencial para alguns grupos. No caso dos primatas, como era de se esperar, por ser este um grupo de hábito predominantemente arborícola, houve uma tendência de ocorrência nos habitats florestais, quais sejam: floresta ripária $(F R)$, floresta semidecídua $(F S D)$ e floresta homogênea de eucaliptos (EU).

As espécies de grandes e médios mamíferos mais frequentes na floresta homogênea de eucaliptos foram aquelas altamente territorialistas e, na grande maioria das vezes, de maior área domiciliar, como a onça-parda (Felis concolor), o lobo-guará (Chrysocyon brachyurus), o veado (Mazama sp) e o macaco-prego (Cebus apella). Estas espécies pareciam utilizar mais de uma mancha da vegetação nativa remanescente, também transitando pelo reflorestamento. As demais espécies de médio e grande portes, como a jaritataca (Conepatus chinga), o quati (Nasua nasua), a capivara (Hidrochaeris hidrochaeris), o tamanduá-bandeira (Myrmecophaga tridactyla), apareceram nas matas primárias e secundárias heterogêneas e na zona limítrofe entre o cerrado e o reflorestamento, sempre nas proximidades do curso d'água. Talamoni (1996), encontrou, em levantamento realizado na Estação Ecológica de Jataí, a pouco mais de $3 \mathrm{Km}$ da A.R.I.E. Cerrado Pé-de-Gigante, todas as espécies catalogadas neste estudo e mais outras duas que não foram avistadas neste estudo: o cateto (Tayassu tajacu) e a anta (Tapirus terrestris), cuja ocorrência na região não era registrada desde meados dos anos 80 . 
Com respeito às reintroduções realizadas, é importante considerar que a Estação Ecológica de Jataí é o maior fragmento do "arquipélago" de manchas nativas remanescentes da região em que se encontra a A.R.I.E. Cerrado Pé-de-Gigante. Entre a Estação Ecológica de Jataí e a A.R.I.E. Cerrado Pé-de-Giagante existem dois tipos de monocultura: de eucalipto (adjacente à A.R.I.E.) e de cana-de-açúcar (adjacente à Estação Ecológica). É possível que muitos mamíferos de médio e grande porte, com maior área domiciliar e que foram reintroduzidos na Estação Ecológica de Jataí, utilizem estas monoculturas para atingir os demais fragmentos deste "arquipélago", entre elas a A.R.I.E. Cerrado Pé-de-Gigante.

Estas reintroduções realizadas na Estação Ecológica de Jataí, apesar de terem sido monitoradas pela Polícia Florestal e pelo Instituto Florestal, se deram de maneira pouco sistemática ou sequer organizada. Não se encontra na sede administrativa da Estação Ecológica os documentos de todas as reintroduções realmente feitas na área, sendo a listagem oferecida neste relatório extrememente subestimada. Além disso, em nenhum dos documentos constava o nome científico da espécie libertada, muitos deles não apresentavam nem mesmo o nome vulgar, apesar de toda operação ter sido acompanhada por técnicos da Polícia Florestal e do Instituto Florestal local, além daqueles das instituições doadoras. Por fim, algumas fichas não tinham registrada a procedência do animal. Fica claro aqui que estas reintroduções se deram de uma forma não satisfatória, podendo comprometer as espécies que já residiam na área (introdução de doenças, problemas com territorialidade, etc), além de não garantir a vida daquelas que foram reintroduzidas.

A aplicação do questionário à população colaborou de forma a se saber qual é o conhecimento desta em relação à fauna local (principalmente a mastofauna de médio e grande portes), além de trazer informações sobre animais como a onça-pintada (Panthera onca), o cateto (Tayassu pecari) e a anta (Tapirus terrestris), que ocorriam anteriormente na região e desapareceram nos últimos dez anos. As entrevistas revelaram também hábitos da fauna local, possibilitando o avistamento de algumas espécies como o lobo-guará (Chrysocyon brachiurus) e o veado (Mazama sp).

Outro aspecto interessante da aplicação do questionário à população local foi a reconstituição da história da região, que possibilitou esclarecer as várias etapas de desenvolvimento encontradas nas fisionomias da A.R.I.E., uma vez que a retirada de madeira do cerrado pela Usina Vassununga e para a construção da estrada de ferro Mogiana foi bastante intensa no fim da década de 60 , além da abertura de pequenas estradas para 0 transporte desta madeira em pequenos caminhões da época. O registro de fogo no interior da Reserva também foi conhecido nestas entrevistas, revelando que o último incêndio ocorreu há 
onze anos atrás. O questionário ofereceu também uma explicação bastante plausível sobre a grande quantidade de gramíneas exóticas encontradas no interior da A.R.I.E., já que os trabalhadores rurais que arrendavam terras da Usina Vassununga para criação extensiva de gado, semeavam o cerrado com estas gramíneas para formação de pasto. Todos estes fatores podem ter tido ( e ainda têm, como no caso das gramíneas invasoras) influência direta ou indireta sobre a fauna, alterando seus habitats e os recursos alimentares disponíveis.

A estrutura espacial da paisagem é primordial para a compreensão dos efeitos da fragmentação. Esta estrutura consiste na relação entre os fragmentos e a matriz circundante, que irá influenciar na dispersão dos organismos entre os fragmentos, determinando graus de conectividade entre eles (Fahrig \& Merriam, 1995). O grau de conectividade entre fragmentos naturais tem um importante papel no processo de extinção de espécies em paisagens fragmentadas (Beeby,1993). Numa das formas de se aumentar a conectividade entre fragmentos é através da criação e manutenção de corredores de árvores nativas entre as paisagens antropizadas. A sobrevivência das populações numa escala regional depende também da recolonização do local em que vivem por indivíduos vindos de outros fragmentos próximos, quando extinções locais ocorrem (Addicott, 1978; Henderson, 1985; Harrison, 1988; Paine, 1988; Wegner \& Merrian, 1990; Merrian \& Wegner, 1992; Villard, 1992 apud Fahrig \& Merriam, 1995), daí a importância da manutenção destes corredores, permitindoa passagem dos indivíduos entre um fragmento e outro. Desta forma, a matriz predominante de eucalipto que permeia a A.R.I.E. Cerrado Pé-de-Gigante, as outras glebas do Parque Estadual do Vassununga e a Estação Ecológica de Jataí parece exercer um efeito satisfatório no que diz respeito à conectividade destes remanescentes.

Andrèn (1994) afirma que a diversidade total de uma paisagem, pode crescer quando vários fragmentos estão próximos, aproximando-se o máximo possível de um habitat contínuo. Fernandez (1997) ainda afirma que certas espécies, as supertramps, ocorrem com mais frequência em comunidades pobres, outras, em comunidades de riqueza intermediária, e outras, as hihg-S, apenas em comunidades com elevada riqueza de espécies. As espécies high$S$ geralmente ocupam um alto nível trófico e/ou grande tamanho corporal e/ou alto grau de especialização; elas devem despertar maiores cuidados, pois são elas as previsivelmente as primeiras a sofrerem os efeitos deletérios da fragmentação de habitats, podendo ser assumidas como espécies-bandeira para a luta na preservação de um fragmento.

Fonseca \& Robinson (1990), num estudo no Parque Estadual do Rio Doce, observaram que a perda dos predadores de topo (high-S) pode aumentar a abundância de predadores intermediários, reduzindo a diversidade dos mamíferos menores por eles predados, devido a um desequiíbrio ecológico. Mankin \& Warner (1997) porém, levantam algumas 
dúvidas sobre os efeitos da perda dos grandes mamíferos e de espécies importantes em diversos níveis tróficos de uma comunidade. Para tanto, seria necessário saber seus nichos na paisagem natural, conhecer as relações ecológicas estabeleccidas entre as espécies e o papel destas na dinâmica da comunidade. Da mesma forma, Winker et al (1995) afirmam que, apesar de largamente utilizada, a densidade de populações podem não ser um bom indicador da sustentabilidade do habitat.

Neste estudo, verificou-se a ocorrência de diversas espécies de grande porte, tidas como high $-S$, inclusive ameaçadas de extinção, como a onça- parda (Felis concolor) e o lobo-guará (Chrysocyon brachyurus) na A.R.I.E. Cerrado Pé-de-Gigante, apesar de seu tamanho reduzido. Isso nos leva a crer que os demais fragmentos de vegetação nativa que ocorrem na região são também importantes para a manutenção destas populações, o que torna imprescindível a manutenção efetiva de corredores biológicos entre estes fragmentos.

Embora ainda poucos estudos a esse respeito existam no Brasil, dados de outros países atestam para a importância dos corredores biológicos. Bennett (1990) estudou uma população de pequenos mamíferos numa paisagem fragmentada da Austrália e comprovou que a sobrevivência da população era facilitada pela movimentação dos indivíduos entre os fragmentos. Mankin \& Warner (1997) afirmam que corredores são habitats em potencial para mamíferos no meio-oeste americano, e estes devem ser suficientes para movimentação e reprodução.

Dados bibliográficos reforçam a idéia de uma situação percebida em campo, onde a floresta de eucaliptos poderia estar agindo como um corredor biológico entre as manchas remanescentes de cerrado. Stallings (1989) afirma que os reflorestamentos são bem menos impactantes que outras monoculturas para a fauna. Além disso, se houver um subbosque nativo nestas florestas de eucalipto, este oferece mais recursos alimentares e refúgios para fauna, e esta pode, inclusive, ignorar o estrato emergente da floresta de eucaliptos, utilizando somente o sub-bosque. Em outro estudo, Stallings (1990) afirma que alguns pequenos mamíferos poderiam estar também utilizando a borda do reflorestamento que fazia limite com sua área de estudo, ou simplesmente passando pela floresta de eucaliptos, com segurança e abrigo, em direção a outro fragmento nativo da região. Sistemas florestais na borda das reservas sempre diminuem o efeito de borda nestas, ainda que este sistema seja homogêneo (Viana, 1997).

Dentro de florestas homogêneas de eucalipto da CELPAV - Votorantim Celulose e Papel, alguns estudos preliminares foram realizados e comprovou-se o uso destes reflorestamentos como corredores biológicos entre fragmentos de vegetação nativa, comprovando o trânsito de animais de maior porte como o lobo-guará ( Chrysocyon brachiurus) 
e a onça-parda (Felis concolor), e um aumento na população de catetos (Tayassu pecari), em regiões onde este corredor biológico foi mantido de forma efetiva (Camargo,F. com. pess.). O estudo da qualidade de tais corredores como rotas dispersoras é essencial para a compreensão da paisagem (Fahrig \& Merriam, 1995).

Não se pode, entretanto, ignorar o fato de que uma monocultura, indiscutivelmente, reduz a biodiversidade local, se comparada à vegetação original. Dietz et al. (1975), compararam quatro fragmentos, dois heterogêneos e dois homogêneos, e o fragmento homogêneo de eucaliptos foi o que apresentou menor diversidade faunística, sendo a floresta homogênea de eucalipto um fator de distúrbio. Neste estudo, a escassez de pequenos roedores na floresta homogênea de eucaliptos e a presença de grandes mamíferos, pode revelar o trânsito e possivelmente a predação exercida por estes últimos na população de pequenos mamíferos, apresentando-se como predadores de topo de cadeia (Eisenberg, 1980 apud Stallings, 1989); a presença de predadores de topo de cadeia, frequentemente, indica um ambiente satisfatoriamente provido de recursos alimentares para todos os níveis tróficos. Novamente, a existência de tais predadores de topo (high - S) na área de estudo indica que ainda há uma qualidade ambiental relativamente boa, capaz de mantê-los.

$\mathrm{Na}$ A.R.I.E. Cerrado Pé-de-Gigante existem algumas perturbações antropogênicas que exercem, indiscutivelmente, pressões negativas sobre sua fauna e flora, podendo até mesmo ser consideradas fatores de impacto ambiental. A definição do que seja "impacto ambiental" vem expressa no artigo $1^{\circ}$ da Resolução $n^{\circ}$ 001/86 do CONAMA: “ (...) considera-se impacto ambiental qualquer alteração das propriedades físicas, químicas e biológicas do meio ambiente, causada por qualquer forma de matéria ou energia resultante das atividades humanas que, direta ou indiretamente, afetam 1) a saúde, a segurança e o bem-estar da população; 2) as atividades sociais e econômicas; 3) a biota; 4) as condições estéticas e sanitárias do meio ambiente; 5) a qualidade dos recursos ambientais." (Mirra, 1998).

Neste sentido, bastante impactante é a Via Anhanguera, no limite oriental da área considerada, tornando-a mais vulnerável a incêndios florestais, além de favorecer o atropelamento de animais que cruzam suas pistas, procurando alcançar o reforestamento de eucaliptos que existe na margem oposta. Este limite com a rodovia também facilita a introdução de espécies exóticas e a entrada de caçadores ou curiosos na reserva. Os demais limites da A.R.I.E. se dão com florestas homogêneas de eucalipto que, apesar de funcionarem muitas vezes como um "tampão" para esta área, além de comunicá-la com os demais fragmentos, exercem também pressões negativas, associadas as uso de agrotóxicos e de fertilizantes que podem contaminar o curso d'água e animais que entrem em contato com estas substâncias. 
A presença de funcionários das companhias de reflorestamento, que deixam lixo, circulam de automóveis entre os talhões de eucalipto e nos limites da reserva e, finalmente, o próprio corte do eucalipto, que se dá em intervalos bastante grandes (de 5 a 7 anos), são ações altamente impactantes para a flora e a fauna locais.

O processo de fragmentação de ecossistemas ressalta cada vez mais a importância das Unidades de Conservação, pois a conservação in situ é o método mais eficaz para se manter intactas a complexa estrutura e a dinâmica das interações entre as espécies e, em consequência, a continuidade dos processos evolutivos que originam a biodiversidade (Santos Filho, 1995).

A importância da preservação de um área pequena, como é o caso da A.R.I.E. Cerrado Pé-de-Gigante, é bastante polêmica, apesar da presença de corredores, que também são muito questionados (Hobbs, 1992; Lindenmayer \& Nix, 1993 apud Fernandez, 1997). Noss \& Cooperrider (1994 apud Shwartz \& Mantgen, 1997) afirmam que "o antigo modelo de parques isolados está falido. Ao menos que possua milhões de acres, a reserva não pode manter a biodiversidade a longo prazo". Tal afirmação é bastante pertinente à nossa realidade, já que a cobertura vegetal natural do país persiste apenas em manchas ou fragmentos cercados por uma paisagem antropogênica. Pickett \& Thompson (1978 apud Shwartz \& Mantgen, 1997) definem que a menor área para se proteger é aquela "pequena área com um regime de distúrbios natural e que mantenha fontes de recolonização".

Considerando áreas altamente ocupadas e sob pressão antrópica, muito comuns atualmente, a biologia da conservação passou a encarar fragmentos como um dos objetivos para preservação da biodiversidade local. Este é o caso da A.R.I.E. Cerrado Pé-deGiagante, uma área pequena, porém, com fontes de recolonização, constituídos pelos outros fragmentos de vegetação nativa próximos. A comunicação entre estes fragmentos proporcionada pelo reflorestamento de eucaliptos favorece a manutenção de populações de mamíferos de médio e grande porte. O trânsito entre estes fragmentos pode ainda ser comprovado pelo grande número de animais atropelados que foram encontrados. Porém, não se sabe o tamanho destas populações e qual nível de endocruzamento que pode estar ocorrendo entre elas.

Por fim, os resultados obtidos neste trabalho, mostram uma grande heterogeneidade fisionômica dentro da A.R.I.E., com o oferecimento de um grande número de habitats e recursos diversificados e que têm implicações diretas com a fauna associada. Esta grande diversidade biológica e de habitats, aliada ao fato da A.R.I.E. Pé-de-Gigante se encontrar numa situação positiva quanto aos ecossistemas circundantes e quanto à sua proximidade de a outras fragmentos de vegetação nativa, leva à conclusão de que, embora 
pareça uma área pequena, a A.R.I.E. Cerrado Pé-de-Gigante, devido à sua condição de conectividade com outras manchas remanescentes de vegetação nativa do Estado de São Paulo, quase totalmente cercada de monocultura de eucalipto, constitui-se em um dos últimos refúgios representativos da biodiversidade de cerrado do Estado, mostrando a importância de sua proteção e manejo adequados. Tal afirmação concorda com Sauders et al (1995), que afirmam que o manejo de ecossistemas fragmentados tem dois componentes básicos: o manejo da área remanescente (enfocando a dinâmica interna do fragmento) e o manejo de suas influências externas. Afirmam ainda que, para pequenos remanescentes o manejo deve ser primariamente dirigido ao controle das influências externas, pois os impactos nessas áreas geralmente têm origem no entorno.

Assim sendo, para incrementar a proteção à biodiversidade oferecida pela Unidade de Conservação estudada e pelas adjacentes, algumas medidas deveriam ser implantadas no manejo da floresta homogênea de eucaliptos já que é ela uma das grandes responsáveis pela manutenção da fauna local, portanto possui relevante importância para a manutenção da biodiversidade da região. Sugere-se as seguintes ações:

- Promover o plantio de espécies nativas nas áreas de proteção permanente que se encontram dentro dos limites das terras das empresas de reflorestamento, dando especial atenção às matas ciliares dos cursos d'água existentes nestas terras. Os benefícios das matas ciliares são conhecidos no controle da erosão das margens dos rios e no estabelecimento da ligação entre outros fragmentos de vegetação, funcionando como corredores biológicos ( Simberloff \& Abele, 1976). A troca gênica entre sub-populações da fauna, bem como a disseminação de propágulos vegetais são decorrências fundamentais dos corredores à manutenção das espécies (Shafer, 1990);

- Manter um sub-bosque dentro das florestas homogêneas de eucalipto, sendo este preferencialmente de vegetação nativa arbórea ou arbustiva, a fim de fornecer recursos alimentares para a fauna local que transita por estas florestas e aumentar a sua complexidade estrutural, através de um maior número de estratos. Tal prática é praticamente indispensável para a manutenção da fauna a longo prazo, além de ser bastante importante para o controle de pragas e reciclagem de nutrientes dentro do reflorestamento de eucaliptos (Paula Lima, 1996) ;

- Manejar o corte da floresta homogênea, pois o corte simultâneo das árvores em grandes talhões elimina instantaneamente a cobertura vegetal, anteriormente florestal, nestes locais, privando a fauna que a utilizava, principalmente como abrigo. É recomendável que se deixe corredores de árvores para servirem de comunicação entre os 
talhões não cortados, evitando que os animais fiquem "ilhados" nos talhões vegetados (Pivello, 1997);

- Manter uma proteção intensiva contra o fogo, principalmente nas áreas adjacentes aos canaviais que exercem a prática de queimadas para preparar o solo para o plantio, bem como nas áreas de cerrado nativo, os quais na estação seca, alcançam uma alta flamabilidade, provocando um fogo de grande intensidade, bem como os eucaliptos;

- Reprimir a prática da caça nas terras da empresa de reflorestamento e consequentemente em suas áreas adjacentes. De acordo com o Código de Proteção à Fauna (Lei $n^{\circ}$ 5197/67), “os animais de qualquer espécie, em qualquer fase de seu desenvolvimento e que vivem naturalmente fora de cativeiro, constituindo a fauna silvestre, bem como seus ninhos, abrigos e criadouros naturais são propriedade do Estado, sendo proibida sua utilização, destruição, caça ou apanha";

- Promover o controle de gramíneas exóticas. O controle das gramíneas exóticas que geralmente ocorrem em áreas de cerrado, é bastante complicado, pelo fato delas lá encontrarem um ambiente muito propício e competirem com as espécies nativas (Pivello, 1992). Assim, deve-se evitar o plantio destas gramíneas africanas ao redor de unidades de conservação de cerrado;

- Promover atividades de educação ambiental, patrocinada pelas empresas de reflorestamento, com os funcionários e suas famílias, bem como com a população da região onde a empresa atua, a fim de criar uma consciência ecológica naqueles que interagem diretamente com aquela região;

- Realizar reintroduções de fauna somente após estudos populacionais das espécies existentes na área de soltura que confirmem a capacidade da região em absorver estes indivíduos;

- Estimular a pesquisa dentro das florestas homogêneas de eucalipto, patrocinando consórcios com universidades interessadas. 


\section{Referências Bibliográficas :}

Ab'SABER. 1971. Contribuição à geomorfologia da área dos cerrados. IN: FERRI, M.G.

Simpósio sobre o cerrado, Procedings of the ... EDUSP, São Paulo. 94-104pp.

ALHO, C.J.R. 1981. Small mammals populations of Brazilian Cerrado: the dependence of abundance and diversity on habitat complexity. Revta. Bras. Biol., 41:223-230.

ALHO, C.J.R. 1986. Patterns of habitat utilization by small population cerrado biome of central Brazil. Mammalia. 50 (4): 447-460.

ALHO, C.J.R. 1994. Distribuição da fauna num gradiente de recursos em mosaico. IN: Pinto, M.N. (org.) Cerrado. SEMATEC / Editora UnB, Brasília. pp 213-262.

ALMEIDA, F.F.M. 1974. Fundamentos Geológicos do Relevo Paulista. Instituto de Geografia. Série Teses e Monografias. Universidade de São Paulo. São Paulo.

ANDRËN, H. 1994. Effects of habitat fragmentation on birds and mammals in landscapes with different proportions of suitable habitat: a review. Oikos, 71:355-366.

AUGUST, P.V. 1983. The role of habitat complexity and heterogenity in structuring tropical mammal communities. Ecology, 64:495-513.

AUGUST, P.V. 1984. The role of habitat complexity and heterogenity in structuring tropical mammal communities. Ecology, 64: 1495-1513.

ÁVILA-PIRES, F.D. 1978. Fauna de mamíferos PFERD. Relatório parcial das pesquisas ecológicas no Parque Florestal Estadual Rio Doce. CETEC.

BATALHA, M.A . 1997. Análise da vegetação da ARIE Cerrado Pé-de-Gigante (Santa Rita do Passa-Quatro, SP). Dissertação de Mestrado. Universidade deSão Paulo. São Paulo. Brasil. 
BEEBY, A . 1993. Applying Ecology. Chapman \& Hall. United King.424pp.

BENNETT, A . F. 1990. Habitat corridors and the conservation of small mammals in a fragmented forest environment. Landscape Ecology, 4:109-122.

BERNARDES, A.T.; MACHADO, A.B.M. \& RYLANDS A. B. 1990. Fauna Brasileira Ameaçada de Extinção. Fundação Biodiversitas para a Conservação da Diversidade Biológica. Belo Horizonte. 62pp.

BITENCOURT, M.D.; MESQUITA Jr, H.N.; MANTOVANI, W.; BATALHA, M.; PIVELLO, V.R. 1997. Identificação de Fisionomias de Cerrado com imagem índice de Vegetação. In: LEITE, L.L.; SAITO, C.H. (coord.) 1997. Contribuição ao Conhecimento Ecológico do Cerrado. UnB. Brasília. 320p.

BOHÁC, J.;FUCHS, R. 1991. The structure of animal communities as bioindicators of landscape deteroration. IN: JEFFREY, D.W. \& MADDEN, B. Bioindicators and environmental management. London Academie Press. United King.

BORCHERT, M.; HANSEN, R.L. 1983. Effects of flooding and wildfire on valley side wet campo rodents in central Brazil. Ver. Brasil. Biol., 43(3):229-240.

BUDRY, J.;MERRIAM, H.G. 1988. Connectivity and connectedness: functional versus structural patterns in landscapes. IN: SCHREIBER, K.F. (org.). Connectivity in Landscape Ecology. Procedings of the 2nd International Seminar of the "International Association for Landscape Ecology" Bonn. Germany. 255pp.

BYERLEE, D.; COLLINSON, M; PERRIN, R.; WINKEL; MANN, D.; BIGGS, S. 1980. Plan technologies appropriate to farmers - Concepts and procedures. CIMMYT. Mexico. $71 \mathrm{pp}$.

CARDEL, F.S.; SILVA Jr, M.C. 1988. Distribuição dos diâmetros da regeneração de Mata Atlântica estabelecida sob o plantio de Eucaliptus grandis no município de Dionísio-MG.XL CONGRESSO NACIONAL DE BOTÂNICA, Universidade Federal do Mato Grosso, Cuiabá-MT. 
CASTRO, A. A. J. F. 1987. Florística e fitossociologia de um cerrado marginal brasileiro, Parque Estadual do Vassununga, Santa Rita do Passa-Quatro, SP. Dissertação de Mestrado. Universidade de Campinas.

CERQUEIRA, R.; GENTILE, R.; FERNANDEZ, F. A.S.; D'ANDREA, P.S. 1993. A five-year population study of na assemblage of small mammals in southeastern Brazil. Mammalia, 57(4):507-517.

CHARLES-DOMINIQUE, P.; ATRAMENTOWICZ, M.; CHARLES-DOMINIQUE, M.; GERARD, H.; HLADICK, C.M.; PREVOST, M.F. 1981. Les mammiferes frugiveres arboricoles nocturnes d'une foret guyannaise. Ver. Ecol., 35: 341-435.

CHARLES-DOMINIQUE, P. 1983. Ecology and social adaptations in didelphid marsupials: comparison with eutherians of similar ecology. IN: Eisenberg, J.F. and Kleiman, D.G. (eds) Advances in the study of Mammalian Behavior. Spec. Publ. № 7 Amer. Soc. Mamm., Shippensburg Pennsylvania.

COUTINHO, L. M. 1978. O conceito do cerrado. Rev. Bras. Bot., 1:17-23.

COUTINHO, L.M. 1982. Ecological effects of fire in Brazilian Cerrado. IN: HUNTLEY, B.J. \& WALKER. B.H. (eds) Ecology of tropical savannas. Springer-Verlag. Berlin. 273-291pp.

DAVIS, D.E. 1945. The annual cycle of plants, mosquitos, birds and mammals in two Brazilian forests. Ecol.Monog., 15:244-295.

De GRAFF, R.M.; MILLER, R.I. 1996. Conservation of Faunal Diversity in Forested Landscapes. Chapman \& Hall. London.United King.633pp.

DIAS, M. 1982. Leishmaniose tegumentar americana na zona do Rio Doce, MG. Tese de Doutoramento. Universidade Federal de Minas Gerais. 88pp.

DIAS, B.F.S. 1992. Cerrados: uma caracterização. IN: Dias, B.F.S. Alternativas para o desenvolvimento dos cerrados: manejo e conservação dos recursos naturais renováveis. Brasília, FUNATURA/IBAMA. 97pp. 
DIETZ, J. M.; COUTO, E. A .; ALFENAS, A . C.; FACCINI, A .; SILVA, G. F. 1975. Efeitos de duas plantações de florestas homogêneas sobre populações de mamíferos pequenos. Brasil Flor., 6 (23): 54-57.

DIETZ, J.M. 1983. Notes on the natural history of some small mammals in central Brazil. Ecology, 61:50-56.

DUESER, R.D.; BROWN, W.C.1978. Microhabitats in a forest-floor small mammmal fauna. Ecology,59(1):89-97.

EISENBRG, L.H. 1980. The density and biomass of tropical mammals. IN: SOULÉ, M. Conservation Biology. Sinauer Press, Massachusetts.

EITEN, G. 1978. Delimitation of cerrado concept. Vegetatio, 36(3) : 169-178.

EITEN, G. 1982. Brazilian savannas. IN: HUNTLEY, B.J. \& WALKER, B.H. Ecology of Tropical Savannas. Springer-Verlag. Berlin. 25-47 pp.

EMMONS, L.H. 1980. Ecology and resource partitioning among nine species of african rainforest squirrels. Ecol. Monogr., 50(1): 31-54.

FAHRIG, L.; MERRIAM, G. 1995. Conservation of fragmented populations. IN: EHRENFELD, D. Readings from conservation biology - The landscape perspective. Blackwell. Cambridge. United King.

FELFILI, J.M.; FILGUEIRAS, T.S.; HARIDASAN, M.;SILVA JÚNIOR, M. C.; MENDONÇA, R.C. 1994. Projeto Biogeografia do bioma cerrado: vegetação e solos. Cadernos de Geociências, 12(4):75-166.

FERNANDEZ, F. 1997. Efeitos da fragmentação de ecossistemas: A situação das Unidades de Conservação. CONGRESSO BRASILEIRO DE UNIDADES DE CONSERVAÇÃO. 1997. Curitiba -PR. 
FONSECA, G. A. B. \& REDFORD, K. H. 1984. The mammals of IBGE'S ecological reserve, Brasília, and analysis of the role of gallery forest in increasing diversity. Revta. Brasil. Biol., 44(4): 517-523.

FONSECA, G. A. B. KIERULFF, M. C. M. Biology and natural history of brazilian Atlantic Forest samall mammals. Bull. Florida State Mus. Biol. Sci., 34(3): 99-152, 1989.

FONSECA, G.A .B. 1989. Small mammal species diversity in brazilian tropical primary and secondary forests of different sizes. Revta. Brasil. Zool., 6(3): 381-422.

FONSECA, G. A . B. e ROBINSON, J.G. 1990. Forest size structure: competitive and predatory effects on small communities. Biol. Conser., 53:265-294.

FREITAS, R. O. (coord.). Formações Geológicas de Superfície. Folha Geológica de Luiz Antônio. São Paulo, Instituto de Geografia. (Folha SF-23-V.C-IV-2, escala 1:50.000).

FERRI, M.G. 1969. Espécies de Cerrado. Editora Blücher. São Paulo. 239pp.

FILGUEIRAS, T.S.; PEREIRA, B. A.S. 1990. Flora do Distrito Federal. IN: NOVAES PINTO, M. Cerrado: caracterização, ocupação e perspectivas. UnB e SEMATEC. Brasília - DF.

FONSECA, S. 1984. Propriedades físicas, químicas e microbiológicas de um latossolo vermelho-amarelo sob eucalipto,mata natural e pastagem. Dissertação de Mestrado. Universidade de Viçosa. 78pp.

FLEMING, T.H. 1975Aspects of the population dynamics of three species of opossums and in the Panama canal zone. J.Mamm., 53:619-623.

GILPIN, M. 1996. Metapopulations and Wildelife Conservation: Approaches to Modeling Spatial Structure. IN: Mc CULLOUGH, D.R. Metapopulations and wildelife conservation. Island Press. Washington, USA.

GOEDERT, W. C. 1985. Solos dos cerrados. Nobel / EMBRAPA, São Paulo.422pp. 
GOODLAND, R.; FERRI, M.G. 1979. Ecologia do Cerrado. Itatiaia. Belo Horizonte. 193pp.

GOTELLI, N.J.; KELLEY, W.G. 1993. A general model of metapopulation dynamics. Oikos, 68: 36-44.

GIBBS, P.E.; LEITÃO-FILHO, H.F. e SHEPHERD,G.J. 1983. Floristic composition and community structure in an area of cerrado in SE Brazil. Flora, 173:433-449.

HERINGER, E. P.; BARROSO, G. M.; RIZZO, J. A.; RIZZINI, C. T. 1977. A flora do Cerrado. IN: Simpósio sobre o Cerrado, 4. EDUSP, São Paulo.

HOBBS, R.J. 1992. The role of corridors in conservation: solution or handwagon? Trends in Ecology and Evolution, 7: 389-392.

IBGE - Instituto Brasileiro de Geografia e Estatística. 1992. Atlas Nacional do Brasil. IBGE, Rio de Janeiro.

JORGE PÁDUA, M.T. 1992. Conservação "in situ": Unidades de Conservação. In: DIAS, B.F.S., (Coord). Alternativas de desenvolvimento dos cerrados: manejo e conservação dos recursos naturais renováveis. Brasília, FUNATURA/IBAMA. 97p.

KREBS, C. J. 1989. Ecological Methodology. Harper \& Dow Publishers, New York. 654pp.

LACHER, T.E.; ALHO, C.J.R. 1989. Micrihabitat use among small mammals in the Brazilian pantanal. Jour. Mammal., 70(2): 396-401.

LEMMON, P. E. 1957. A new instrument for measuring forest overstory density. Jour. Fores., 55(9): 667-668.

LINDENMAYER, D.B.; NIX, H. A.1993. Ecological principles for the design of wildlife corridors. Conservation Biology, 55:77-92.

LOPES, I.V.; BASTOS FILHO, G.S,; BILLER, D.; BALE, M. 1996. Gestão Ambiental no Brasil. Fundação Getúlio Vargas, Rio de Janeiro. 377 pp. 
MANKIN, P.C.; WARNER, R.E. 1997. Mammals of Illinois and the Midwest: Ecological and Conservation Issues for Human-Dominate Landscapes. IN: SCHWARTZ, M.W.

Conservation in Highly Fragmented Lanscapes. Chapman \& Hall. USA. 436pp.

Mc Guiness, K. A. 1984. Equation and explanations in the study of species-area curves. Biological Review, 59:423-440.

Mc MANUS, J. J.; NELLIS, D.W. 1972. Relative efficiencies of four small mammal traps. Jour. Mammal., 53 (4) 869-873.

Mc KINNOn, K. 1996. Managing Protect Areas in the Tropics. UICN, Cambridge. United King.295pp.

MENDONÇA, R.C.; FELFILI, J.M.; WALTER, B.M.T.; SILVA JÚNIOR, M.C.; REZENDE, A . V.; FILGUEIRAS, T. S.; NOGUEIRA, P.E. 1998. Flora Vascular do Cerrado. IN: SANO, S.M. \& ALMEIDA, S.P. Cerrado - Ambiente e flora. EMBRAPA, Planaltina - DF. Pp 289-556.

MESQUITA JR.,H.N.1998. Análise temporal com sensor orbital de unidades fisionômicas de cerrado na Gleba Pé-de-Gigante ( Parque Estadual do Vassununga - SP). Dissertação de Mestrado. Universidade de São Paulo, São Paulo.

MIRRA, A . L. V. 1998. Impacto ambiental. Aspectos da legislação brasileira. Editora Oliveira Mendes,São Paulo. 69pp.

MORELLATO, P.C. 1995. As estações do ano na floresta. IN: MORELLATO. P.C. \& LEITÃO FILHO, H.F. (orgs.). Ecologia e Preservação de uma floresta tropical Urbana. Reserva de Santa Genebra. Editora da Universidade de Campinas. pp.37-41.

MULLER-DOMBOIS, D. \& ELLENBERG, H. 1974. Aims and methods of vegetation ecology. John Willey and Sons, New York. USA.

NITIKMAN, L.Z.; MARES, M.A .1987. Ecology of small mammals in a gallery forest of Central Brazil. Anna. Carneg. Mus., 56 (2) : 75-95. 
OLIVEIRA, J.B.; PRADO, H. \& ALMEIDA, C.L.F. 1982. Levantamento Pedológico Semidetalhado do Estado de São Paulo (escala 1: 100.000), Quadrícula de Descalvado, Folha SF 23-V-C-IV. Rio de Janeiro, EMBRAPA/SAA/CPA/IAC.

OPDAM, P. 1988 Populations in fragmented landscape. IN: KARL FRIEDRICH SCHREIBER (org.).Connectivity in Landscape Ecology. Procedings of the 2nd International Seminar of the "International Association for Landscape Ecology" Bonn. Germany.

PAULA LIMA, W. 1996. Impacto Ambiental do Eucalipto. EDUSP, São Paulo. 301p.

PAGLIA, A . P.; DE MARCO, P.; COSTA, F.M.; PEREIRA, R. F.; LESSA, G. 1995. Heterogeneidade estrutural e diversidade de pequenos mamíferos em um fragmento de mata secundária de Minas Gerais, Brasil. Revta. Bras. Zool., 12 (1) : 67-79.

PEREIRA, B. S. 1992. Flora nativa dos cerrados. IN: DIAS, B.S. F. Alternativas para o desenvolvimento dos cerrados: manejo e conservação dos recursos naturais renováveis.Brasília, FUNATURA/IBAMA. 97pp.

PIELOU, E.C. 1984. The interpretation of ecological data - A primer on classification and ordenation. JohnWilley \& Sons, New York. 263pp.

PIVELLO, V. R. 1992. An expert system for the use of prescribed fires in the management of Brazilian savannas. PhD THESIS. Imperial College of Science, Technology and Medicine. London. United King. 276pp.

PIVELLO, V.R. 1996. Primeiro Relatório de Atividades do Projeto: Plano de Manejo para a Reserva Cerrado Pé-de-Gigante. USP/ FAPESP. Processo 95/0350-1.São Paulo. (não publicado).

PIVELLO, V.R. 1997. Segundo Relatório de Atividades do Projeto: Plano de Manejo para a Reserva Cerrado Pé-de-Gigante. USP/FAPESP. Processo 95/0350-1. São Paulo. (não publicado). 
RIZZINI, C.T. 1971. A flora do cerrado - Análise florística das savanas centrais. IN: Ferri.M.G. Simpósio sobre o Cerrado, Procedings of the... EDUSP, São Paulo.105-154pp.

RIZZINI, C.T. 1992. Tratado de Fitigeografia do Brasil. Âmbito Cultural Edições, Rio de Janeiro. 747 pp.

REZENDE, A . V. 1994. Projeto biogeografia do bioma cerrado: vegetação e solos. Caderno de Geociências, 12 (4):75-166.

SANTOS FILHO, P.S. 1995. Fragmentação de habitas: Implicações para conservação in situ. IN: ESTEVES, F. Oecologia Brasiliensis. Vol 1. Universidade Federal do Rio de Janeiro. Rio de Janeiro.

SAUNDERS, D.A . HOBBS, R.J. \& MARGULES, C.R. 1995. Biological consequences of ecossystem fragmentation: a review. IN: EHRENFELD, D. Readings form conservation biology - The landscape perspective. Blackwell, Cambridge. United King.

SEMA - Secretaria do Meio Ambiente do Estado de São Paulo. 1997. Cerrado: bases para conservação e uso sustentável das áreas de cerrado do Estado de São Paulo. SEMA. São Paulo. 184pp.

SEMA - Secretaria do Meio Ambiente do Esatdo de São Paulo. 1998. Fauna ameaçada no Estado de São Paulo. SEMA. São Paulo. 60pp.

SHAFER, C. L. 1990. Nature Reserves - Island Theory and Conservation Practice. Smithsonian Institution Press, Washington. USA. 189pp.

SHIDA, C.N.1999. A ocupação humana no entorno da A.R.I.E. Cerrado Pé-de-Gigante e sua influência sobre os ecossistemas naturais. Dissertação de Mestrado. Universidade de São Paulo. (in.prep.).

SHWARTZ, M.W.; MANTGEN, P. J. 1997. The value of small preserves in chronically fragmented landscapes. IN: SHWARTZ, M. W. Conservation in Highly Fragmented Landscapes. Chapmann \& Hall. USA. 436pp. 
SIMBERLOFF, D.S. \& ABELE L.G. 1976. Island biogeigraphic theory and conservation practice. Science, 191:285-286.

SOUZA, C.G. 1995. Manual Técnico de Pedologia. Instituto Brasileiro de Geografia e Estatística. Rio de Janeiro.

STALLINGS, J.R. 1989. Small mammal inventories in na eastern brazilian park. Bull. Florida. State. Mus., Biol. Sci., 34 (4) : 153-200.

STALLINGS, J.R. 1991. The importance of understorey on wildlife in a brazilian eucalypt platation. Revta. Bras. Zool., 7(3) : 267-276.

STALLINGS, J.R.; FONSECA, G.A .B.; PINTO, L.P.S.; AGUIAR, L.M.S.; SÁBATO, E.L. 1990. Mamíferos do Parque Estadual do Rio Doce, Minas Gerais, Brasil. Rvta. Bras. Zool., $7(4): 663-677$.

VAN HORNE, B. 1983. Density as a misleading indicator of habitat quality. J. Wildl. Manage. 47(4):893-901.

TALAMONI, S. A . 1996. Ecologia de uma comunidade de pequenos mamíferos da Estação Ecológica de Jataí, Município de Luiz Antônio, SP.Tese de Doutoramento. Universidade Federal de São Carlos. São Carlos.173pp.

TALAMONI, S. A. 1990. Dinâmica populacional de Akodon cursor e Oryzomys nigripes em habitat de mata mesófila semidecídua, no município de São Carlos, SP. Dissertação de Mestrado. Universidade Federal de São Carlos. São Carlos. 77pp.

TOLEDO FILHO, D.V. 1984. Composição florística e estrutura fitossociológica da vegetação de Cerrado no município de Luís Antônio (SP). Dissertação de Mestrado. Universidade de Campinas. Campinas.

UICN - Union Internacional para conservación de la Naturaleza. 1982. Directory of Neotropical Protected Areas. Dublin ly cooly Int. Publ. Ltda. 
UICN. Unión Internacional para Conservación de la Naturaleza. 1994. Red List Categories. The world Conservation Union. Species survival commission. Gland. Switzerland. 21pp.

VALLE, C.M., ALVES, M.C.; SANTOS, I.B.; VAREJÃO, J.B.M. 1982. Observações sobre a dinâmica de populações de $Z$. lasiurus e $C$. expulsus e $O$. subflavus em vegetaçào de cerrado no vale do rio das Velhas, MG.Lundiana, 2:71-83.

VIANA, V. 1997. SIMPÓSIO DE FRAGMENTOS FLORESTAIS. ESALQ - Piracicaba.

VIEIRA, M. V. 1989. Dinâmica de populações, variação sazonal de nichos e seleção de microhabitats numa comunidade de roedores de cerrado brasileiro. Dissertação de mestrado. Universidade de Campinas. Campinas.

WARMING,E.1973. Lagoa Santa. EDUSP. São Paulo. 386pp.

WILSON, D.E.; COLE, F.R.; RUDRAN, R.; FOSTER, M.S. 1996. Measuring and monitoring biological diversity - Standard methods for mammals. Smithsonian Instituition Press. USA. 409pp.

WRI/ UICN/ PNUMA - World Research Institute, Union Internacional para Conservación de la Naturaleza, Programa Nacional para o Meio Ambiente. 1992. Estrategia Global para la biodiversidad. Washington. 143pp.

WWF - Fundo Mundial para a Natureza. 1995. De grão em grão o Cerrado perde espaço.

Cerrado - Impactos do Processo de Ocupação. Brasília.66pp.

ZAR, J.H. 1999. Bioestatistical Analysis. 4ª Edição. Printer Hall. New Jersey. USA. 700pp. 
ANEXOS 


\subsection{ANEXO 1: QUESTIONÁRIO}

NOME:

IDADE:

PROFISSÃO:

TEMPO DE RESIDÊNCIA:

QUE ESPÉCIES COSTUMA AVISTAR NA REGIÃO ? ONDE ?

(Avaliar a biodiversidade faunística do local e seus habitats preferenciais)

A ÁREA MUDOU MUITO DESDE QUE A CONHECE?QUAIS FORAM ESTAS MUDANÇAS ? (Avaliar a degradação ambiental da área)

A QUANTIDADE DE ANIMAIS AUMENTOU OU DIMINUIU ? QUAIS FORAM AS ESPÉCIES QUE AUMENTARAM / DIMINUÍRAM ?

(Conhecer quais são as espécies mais afetadas pela pressão antrópica)

POR QUE VOCÊ ACHA QUE A ÁREA MUDOU ? QUEM É O RESPONSÁVEL ?

(Conhecer a opinião da população local a respeito das atividades econômicas do entorno da Reserva)

EXISTEM CAÇADORES NA REGIÃO ? O QUE ELES COSTUMAM CAÇAR ? ELES RESIDEM NA REGIÃO ? COMO ELES CAÇAM ? (ARMAS, ARMADILHAS, ETC). QUAL O USO DADO À CAÇA ?

(Conhecer o perfil do caçador local)

O QUE ELES COSTUAM CAÇAR ? EXISTE PREFERÊNCIA POR ALGUM ANIMAL ? QUAIS ANIMAIS ELES NÃO GOSTAM DE CAÇAR ? SÃO CAÇADOS TAMBÉM AS FÊMEAS E FILHOTES?

(Avaliar quais animais estão sob maior ameaça devido à caça)

A PRESENÇA DO REFLORESTAMENTO FOI MELHOR OU PIOR PARA OS ANIMAIS? VOCÊ VÊ ANIMAIS NO REFLORESTAMENTO ? QUAIS ?

(Mensurar a permeabilidade da monocultura de eucalipto em relação à mastofauna não voadora )

OBSERVA ANIMAIS NOS CANAVIAIS / PLANTAÇÕES DE CÍTRICOS? QUAIS ? MUITOS ? (Avaliar a borda da Reserva )

OBSERVA ANIMAIS ATROPELADOS NA ESTRADA ? QUAIS ? MUITOS ? QUAL O PIOR TRECHO ?

(Avaliar a pressão do entorno )

HOUVE REINTRODUÇÕES DE ANIMAIS NA ÁREA ? QUE ESPÉCIES ? ONDE FOI

CAPTURADA E ONDE FOI SOLTA ? QUEM FEZ ?

(Conhecer casos de reintrodução de espécies na área)

O QUE ERA AQUELE CAPINZAL NO MEIO DA RESERVA ? OS ANIMAIS PROCURAM ESTA ÁREA ? SE SIM, QUAIS ESPÉCIES ?

(Avaliar o histórico da área e a importância do campo aberto)

ONDE OS ANIMAIS COSTUMAM BEBER ÁGUA?

(Conhecer os hábitos da fauna local) 


\subsection{ANEXO 2: FICHA DE CAMPO}

- MEDIDAS CLIMÁTICAS:

\begin{tabular}{|l|l|l|l|l|l|}
\hline & $\begin{array}{c}\text { TEMPERATURA } \\
\text { DO AR }\end{array}$ & $\begin{array}{l}\text { UMIDADE RELATIVA } \\
\text { DO AR }\end{array}$ & $\begin{array}{l}\text { INTENSIDADE } \\
\text { LUMINOSA }\end{array}$ & $\begin{array}{c}\text { COBERTURA } \\
\text { VEGETAL }\end{array}$ & HORA \\
\hline floresta ripária & & & & & \\
\hline campo úmido & & & & & \\
\hline campo cerrado & & & & & \\
\hline $\begin{array}{l}\text { cerrado sensu } \\
\text { stricto }\end{array}$ & & & & & \\
\hline $\begin{array}{l}\text { floresta semi- } \\
\text { decídua }\end{array}$ & & & & & \\
\hline eucalipto & & & & & \\
\hline
\end{tabular}

\begin{tabular}{|l|l|l|l|}
\hline HORA & $\begin{array}{c}\text { TEMPERATURA } \\
\text { DO AR }\end{array}$ & $\begin{array}{l}\text { UMIDADE RELATIVA } \\
\text { DO AR }\end{array}$ & $\begin{array}{l}\text { INTENSIDADE } \\
\text { LUMINOSA }\end{array}$ \\
\hline & & & \\
\hline & & & \\
\hline & & & \\
\hline & & & \\
\hline & & & \\
\hline & & & \\
\hline & & & \\
\hline
\end{tabular}

min: e max: 
- localizaÇÃo e IDENTIFICAÇÃo:

fisionomia:

hora:

aberto

Tempo ( ) nublado

( ) céu

- MEIO FÍSICO :

Topografia:
( ) plano
( ) encosta alta
( ) meia encosta
( ) encosta baixa
( ) depressão
Umidade: ( ) muito seca
do solo
( ) seca
( ) úmida
( ) muito úmida

Cobertura:
( ) rochosa
( ) vegetal
( ) solo nú
( ) morta

Fogo: ( ) recente

( ) antigo

Distância do eixo de drenagem:

$\begin{array}{ll}\text { Compactação } & \text { ( ) alta } \\ \text { do solo: } & \text { ( ) média } \\ & \text { ( ) baixa }\end{array}$
Buraco de tatu:
( ) $\operatorname{sim}$
( ) não
Cupinzeiros:
( ) $\operatorname{sim}$
( ) não
Formigueiros:
( ) $\operatorname{sim}$
( ) não 